\title{
فعالية التدريبات المسرحية في إكساب طلاب الإعلام التربوي ههارات العمل المسرحي دراسة شبة تجريبية
}

\author{
إعـلداد \\ د. أحمل حسين محمد حسر. \\ مدرس المسرح التربوي بقسم الإعلام التربوي \\ كلية التربية النوعية - جامعة المنصورة
}

مجلة بحوث التربية النوعية - جامعة المنصورة

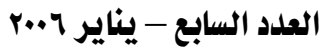


فعالية التلريبات المسرحية في إكساب طلاب الإعلام التربوي مهارات العدل المسرحي لـ 
مجلة بحوث التربية النوعية - العدد السابع - يناير r .. T-

\section{فعالية التدريبات المسرحية في إكساب طلاب الإعلام التربوي \\ ههارات العمل المسرحي دراسة شبة تجريبية}

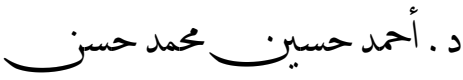

\section{هقدهـيسة}

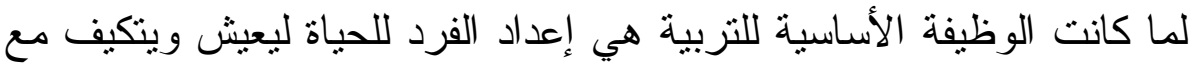

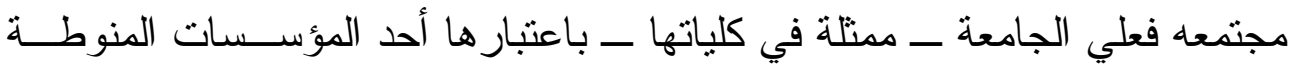
بعملية التربية توفير فرص المرور بالخبرات التعليمية و اكتساب المهار ات التي تلبي

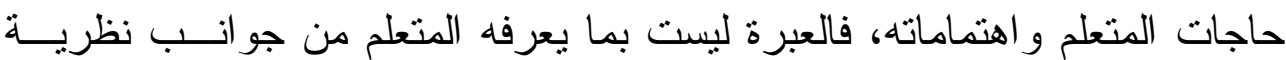
فحسب، بل بما يمكنه أداؤه فهو الأهم .

وكليات التربية النوعية بأقسامها المختلفة ومنها قسم الإعلام التربوي هي أحد

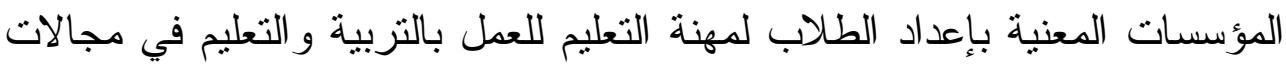

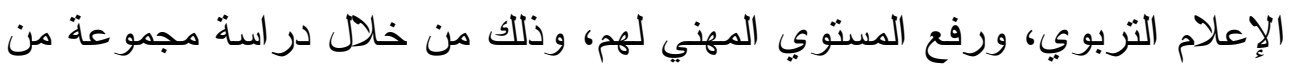

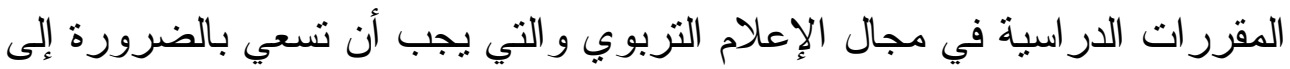

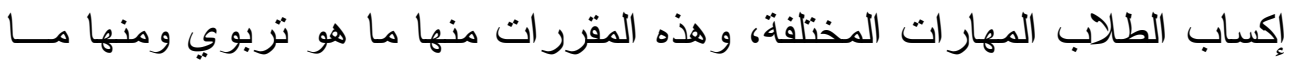

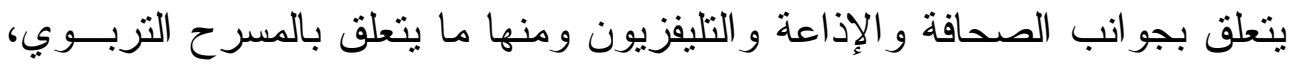
ومن هذه المقررات ما هو نظري ومنها ما هو نظري وتطبيقي معا .

ولكن إذا ما قارنا عدد المو اد التربويــة بعـدـد مــو اد الــصحافة و الإذاعــة

و التليفزيون إلى مو اد المسرح، كما جاء في اللائحة الداخلية لكليتي التزبية النوعية النالية

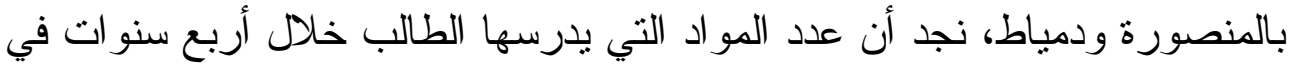

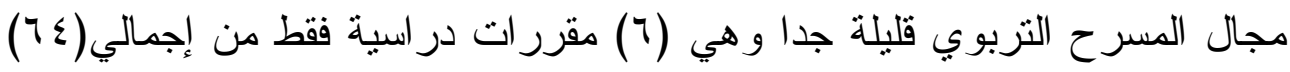

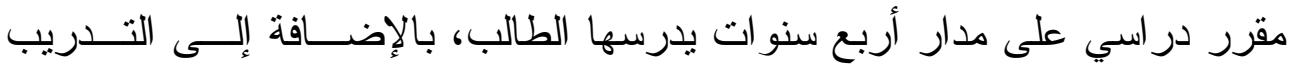


فعالية التلديبات المسرحية في إكساب طلاب الإعلام التربوي مهارات العمل المسرحي

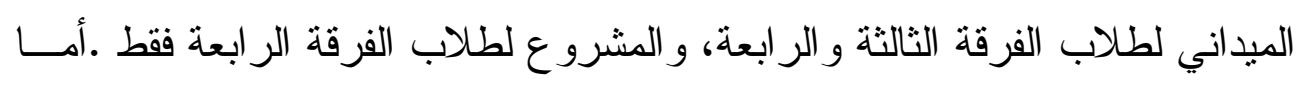

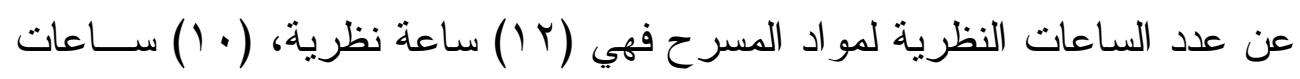

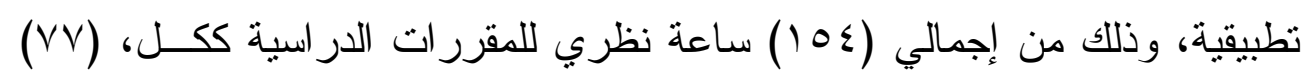

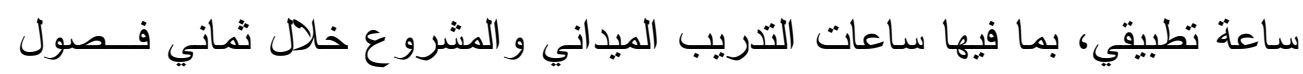
در اسية، يدرس طلاب الإعلام التزبوي بكلية التزبية النوعية بالمنصورة وفر عيهــا

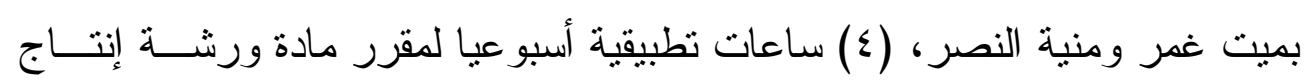

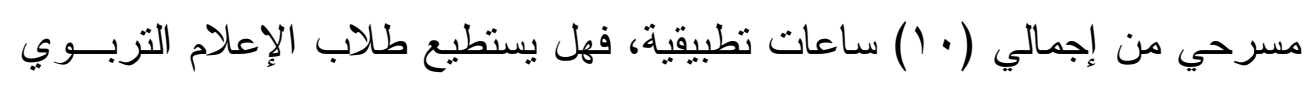

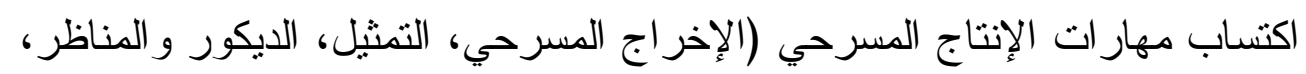

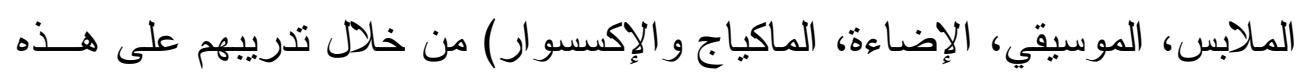

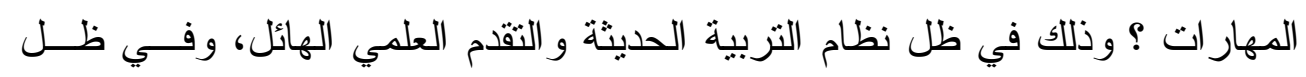

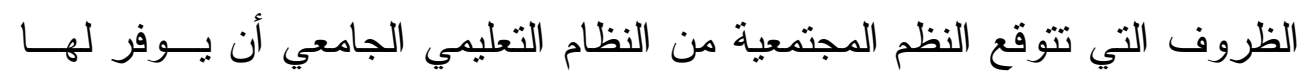
مخرجات - الطلاب - في مستوي جودة يتناسب مع احتياجاتها ورغبات المتعلمين وحاجاتهم، و احتياجات المجتمع ومتطلباته .

ولذا تحاول الدراسة التعرف على مدي فاعلية التـدريبات المـسرحية فـي

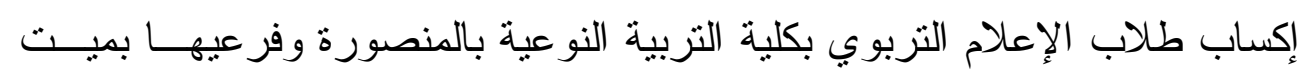

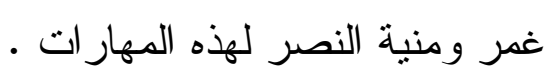

\section{هشكلة الدراسة :}

في ظل نظام الترم الدر اسي - الضيق - الذي تأخــذ بـــه جميــع كليــات

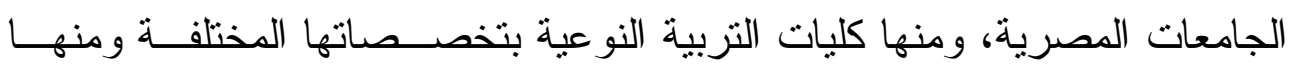

الإعلام التزبوي، هل يستطيع الطلاب اكتساب المهار ات - على اختلاف أنو اعها خلال در استهم في ترم لا يتجاوز اثني عثر أسبوعا أو ثلاثة عشر أسبو عا ؟، وفي

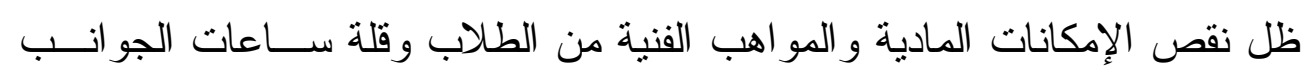


مجلة بحوث التربية النوعية - العدلد السابع - يناير r ..r- مس

التطبيقية التي يتدرب عليها الطلاب بالإضافة إلى عدم وجود التخصص (الصحافة

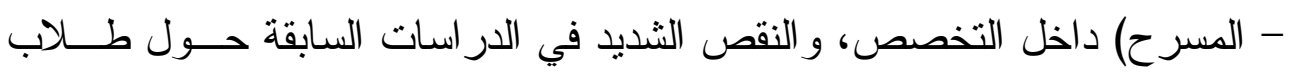
الإعلام التربوي بصفة عامة، و الندرة الثديدة في الدر اســات المتعلقـــة بدر اســــة

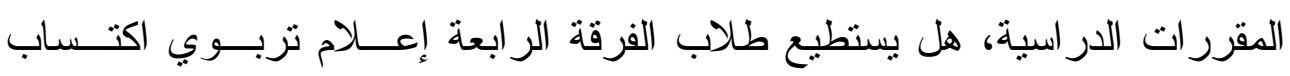
مهار ات العمل المسرحي في إطار در استهم لمقرر "ورشة إنتاج مسرحي"المقــرر در استه خلال الفصل الدر اسي الثاني ؟

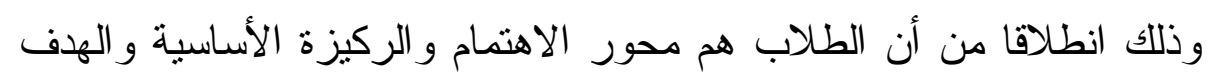
المنشود من ور اء العملية التعليمية، و التي يتوقف نجاحها على طريقـــة إعــدادهم أكاديميا وتربويا وثقافيا بهذه الكليات، ومدي رضاهم ورغبتهم و استعدادهم وميولهم ولهيه

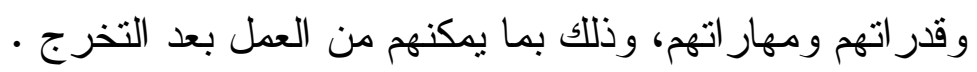
و علي ذلك يحدد الباحث مشكلة الدراسة في التساؤل الرئيسي التالي : ما مدي فعالية التذريبات المسرحية في إكساب طــلاب الإعــلام التربــوي

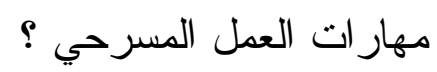

\section{أهميسة الدراسة مقاسة}

ا - تتاولها لموضوع هام يتعلق بإعداد المعلم النوعي بقسم الإعــلام التربــوي

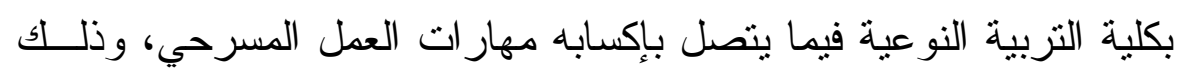

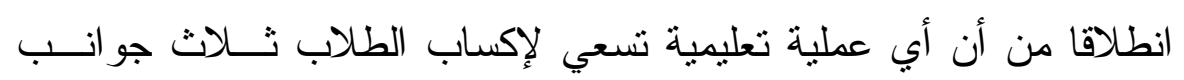

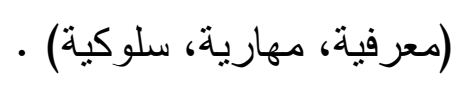

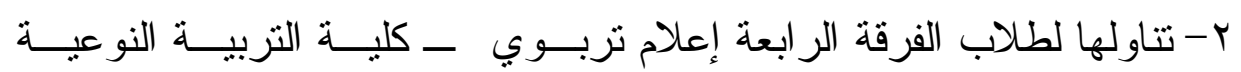

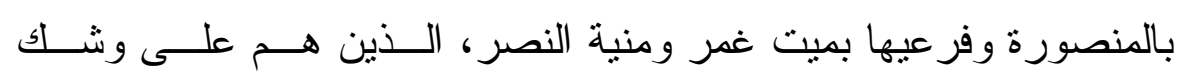

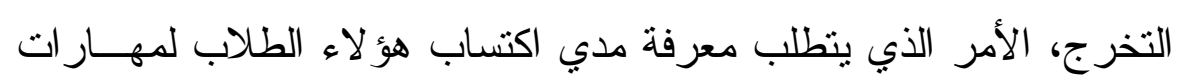
العمل المسرحي قبل تخرجهم و التحاقهم بالمهنة . 
فعالية التدريبات المسرحية في إكساب طلاب الإعلام التربوي مهارات العقل المسرحي ــ

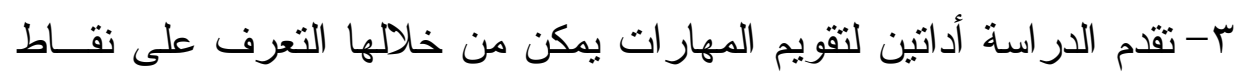
القوة و الضعف لدي الطلاب المعلمين في مهار ات العمل المسسرحي مــن مـن

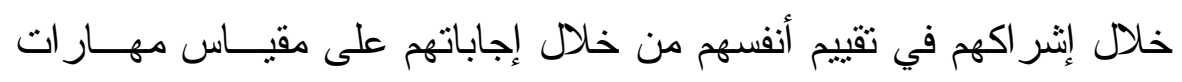

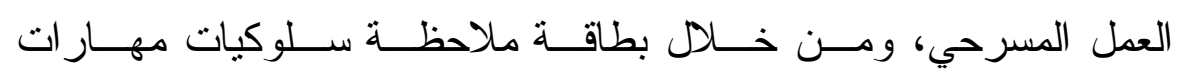

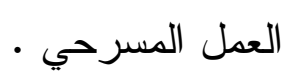

ع - تتو اكب هذه الدر اسة مع الاتجاهات الحديثة المعاصرة في إعــداد الطالــب

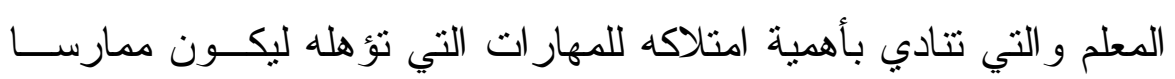

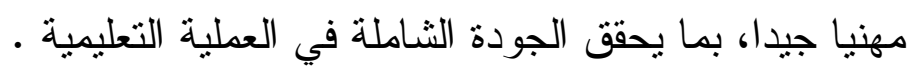
0-توجيه نظر المعنيين بقسم الإعلام بكليات التربية النوعية بضرورة الاهتمام بلهيه

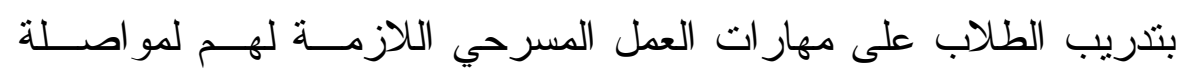
در استهم الجامعية، وكذلك بعد التخرج باعتبار هم معلمي المستقبل .

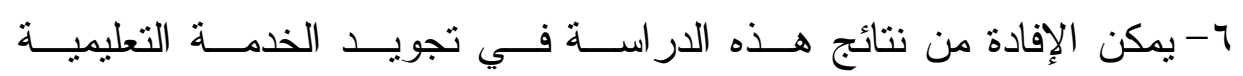

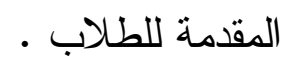

\section{أهداف الدراسة :}

ا- التعرف على مدي فعالية التدريبات المسرحية في إكساب طـــلاب الفرقــة

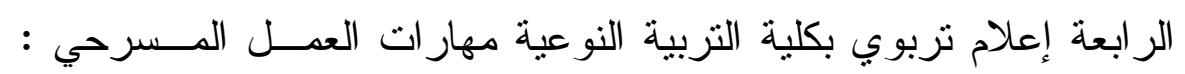

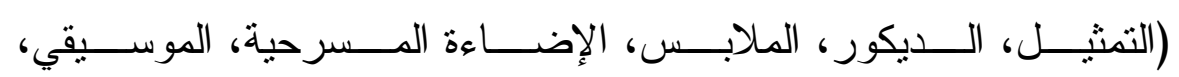

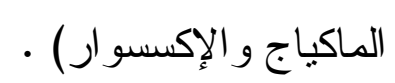

r- - در اسة الفروق بين الطلاب وفقا لمتغير ات الدراسة : النوع، المؤهل قبــلـ الجامعي، المجموعة التي يثارك فيها الطالب، الكلية .

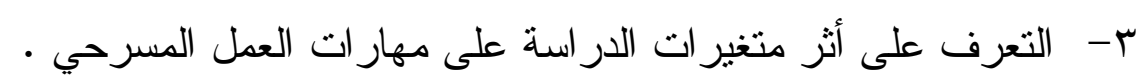


مجلة بحوث التربية النوعية - العدد السابع - يناير 7 . . r مـ

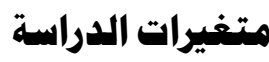

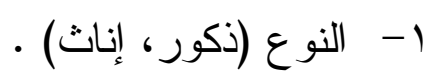

r- المؤهل قبل الجامعي : (تعليم فني صناعي + جامعة عمالية، ثانوي عام) •

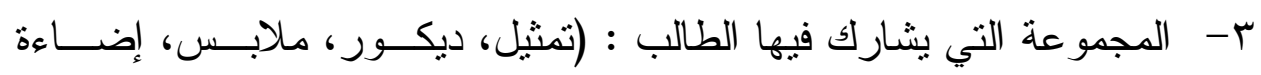

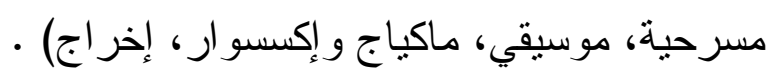

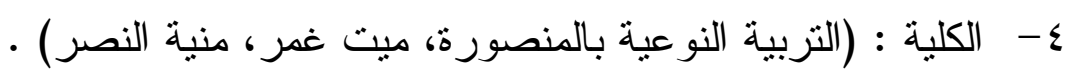

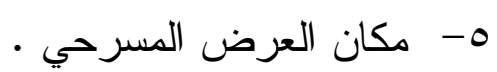

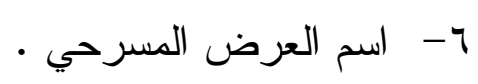

هصطحات الدراسة :

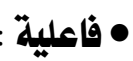

يعبر مصطلح الفاعلية بالدر اسات التربوية التجريبية عن مدي الأثر الــذي

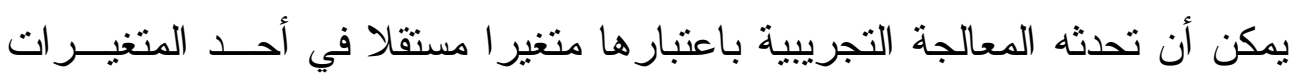
التابعة، أو مدي أثز عامل أو بعض العوامل المستقلة على عامل أو بعض العو امل

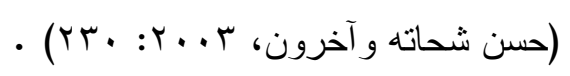

"وهي النشاط التلقائي المؤثر، نقول فاعلية شخص ما، أي ما يبديــهـ مــن

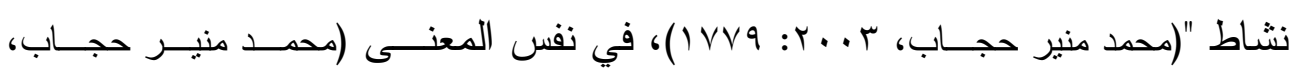
• (rq ז : r. s

\section{•}

"هي عملية التأثير في السلوكيات الإنسانية الفردية للحصول على مهــار ات

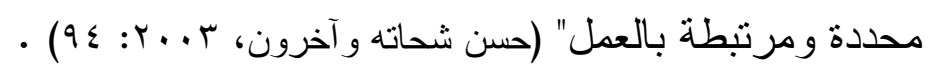


فعالية التلريبات المسرحية في إكساب طلاب الإعلام التربوي مهارات العدل المسرحي

"و هو أسلوب بستهدف مساعدة الطلاب على اكتساب مهار ات معينــة مــنـ

خلال تطبيق أفكار ومباديء ومفاهيم سبق تعلمها علــى مو اقــف عمليــة، وهـــذا الأسلوب يساعد على تثبيت النو احي المعرفية، فضلا على أنه يجعل المتعلم أكثــر بقاءاً وقدرة على الانتقال إلى مو اقف جديدة" (أحمــد حـسين اللقــاني، علــى الجمـلـل، (7):1999

- بينما جاء تعريف التدريبات في معجم المصطلحات الدر امية و المسرحية علـى أنها "التمرينات التي يقوم بتأديتها الممثلون و الحرفيون أثناء تحــضير المـسرحية المزمع عرضها على الجمهور، أي أنها الخطوات العملية نحو الاستيعاب الكامـلـ للنص مدسرحًا، وتشمل تدريبات الحفظ، الحركة، و الإلقـــاء و التــدربيات النهائيـــة (البروفة الجنر ال)" (إبر اهيم حمادة، 9 ( 1 ) ) .

ويتفق الباحث مع هذه التعريفات، ويطـر ح التعريــف الإجر ائـي التــالي

للتدريبات المسرحية بأنها : "التدريبات العملية التي يقوم بها طلاب الفرقة الر ابعـــة إعلام تربوي من خلال النصوص المسرحية في إطار در اسة مقرر مـــادة ورشـــة إنتاج مسرحي، متمثلة في تدريبات الأداء التمثثلي، و إعداد الديكور ورسم المناظر، ، و إعداد وتجهيز المهلابس و استخدام الموسيقي و الإضـاءة و الماكياج و الإكسـسو ارات المسرحية، بهدف إكساب الطلاب مهار ات العمل المسرحي المتعلقة بهذه التدريبات، ليصبحو ا أكثر فعالية وكفاءة في أداء عملهم بعد التخرج .

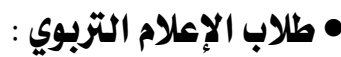

هم طلاب الفرقة الر ابعة إعلام تربوي بكلية التربية النوعيــة بالمنــصورة وفر عيها (ميت غمر ، منية النصر) . 


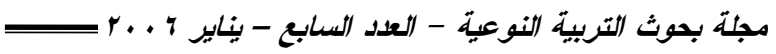

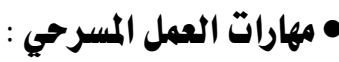

و هي مهار ات الفن المسرحي المتمتلة في الإخر اج الهـسرحي، ومهــارات

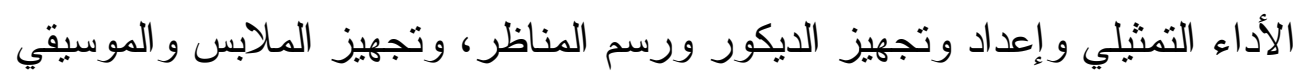

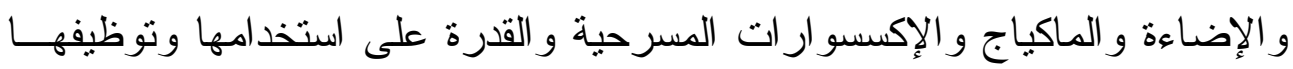
أثثاء التثريبات و العروض المسرحية.

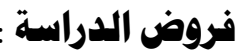

1- لا توجد فروق ذات دلالة إحصائية بين متوسطات درجات الطلاب علـى

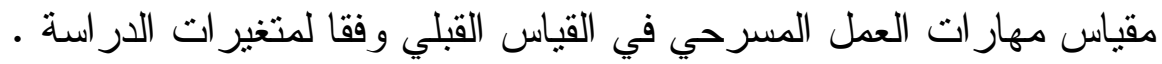

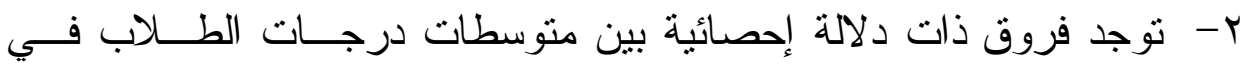

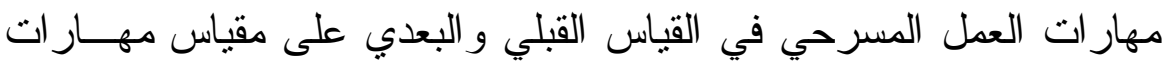
العمل المسرحي لصالح القياس البعدي .

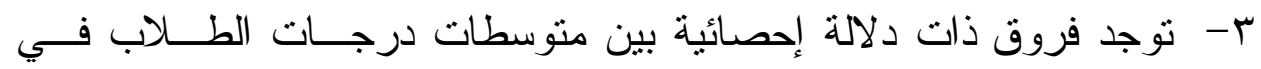

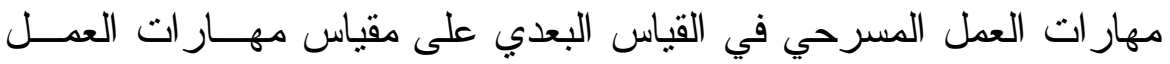
المسرحي وفقا لمتغير النوع (ذكور، إناث) .

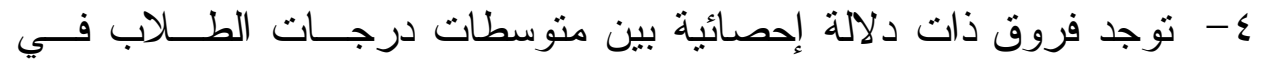

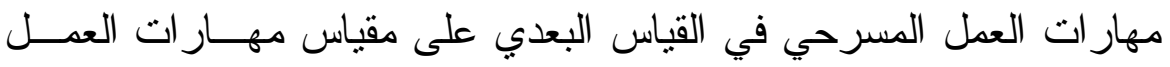
المسرحي وفقا لمتغير المؤهل قبل الجامعي (فني، ثانوي عام) .

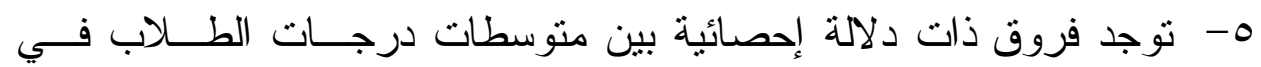

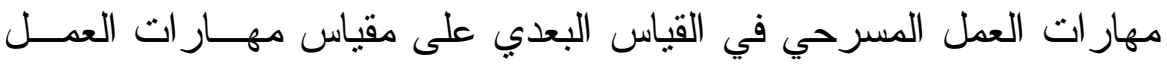
المسرحي وفقا لمتغير المجموعة التي يشارك فيها الطالب (إخر اج، تمثيل، ديكور ، ملابس، إضاءة، موسيقي، ماكياج و إكسسو ار ) .

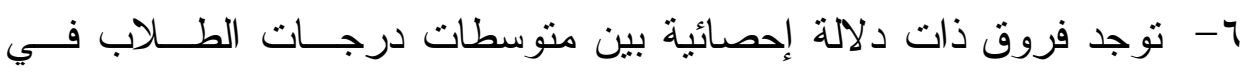


فعالبة التدريبات المسرحية في إكساب طلاب الإعلام التربوي مهارات الععل المسرحي لـ

مهار ات العمل المسرحي في القياس البعدي على مقياس مهــار ات العمــلـ

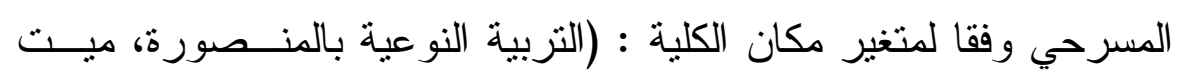

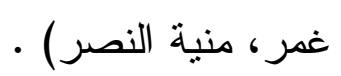
- V - Vد فروق ذات دلالة إحصائية بين متوسطات درجات الطلاب في القياس البعدي على أبعاد مقياس مهار ات العمل المسرحي بين المجموعات التـي لتئي

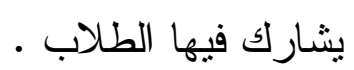
1- توجد فروق ذات دلالة إحصائية بين متوسطات درجات الطلاب في القياس

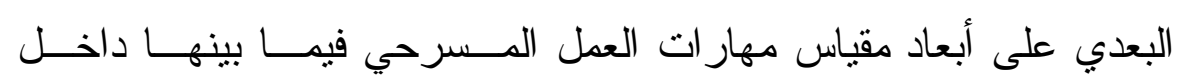
المجموعات التي يشارك فيها الطلاب كل على حده. 9- لا يختلف الملاحظين في تقيمهم لمدي اكتساب الطلاب لمهــار ات العـــل فهـل

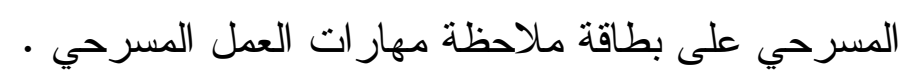

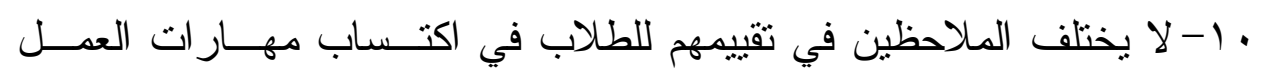

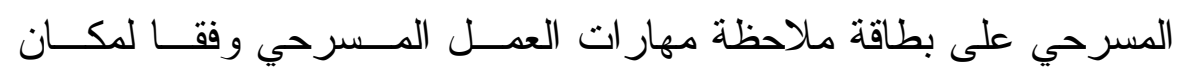

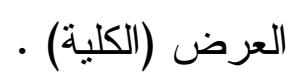

11- الا يختلف الملاحظين في تقييمهم للطلاب في اكتـساب مهــار ات العمـلـل

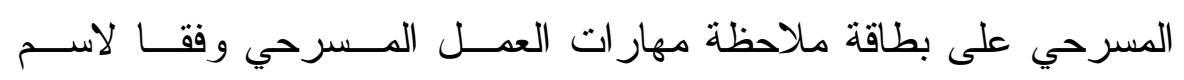

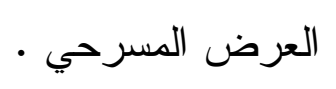

r ا - لا يختلف الملاحظين في تقييمهم للطلاب في اكتـساب مهــار ات العمـلـل

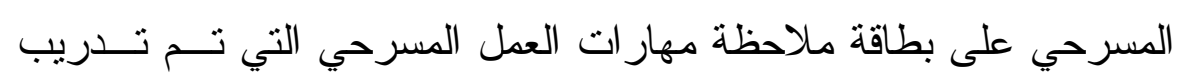

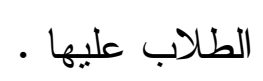
حدود الدراسة :

أ- الحدود الموضوعية : اثتنملت الدر اسة في جانبها النظري على تعريف المهــارة وشروط اكتسابها و أهمية مهار ات العمل المسرحي لطلاب الإعلام التربوي . 


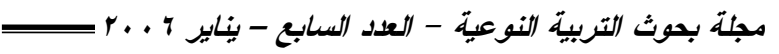

ب- الحلدود المكانيـة : كلية التزبية النو عية جامعة المنصورة وفر عيها (مبت غمر،

منبة النصر )

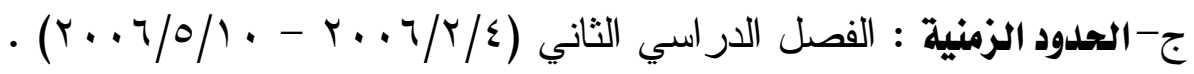

الدراسات السابقة :

دراسة آمال محمود أبو باشا، (1999) استهدفت الدر اسة إعداد وبناء برنامج لتتميــة

بعض مهار ات الاتصال (الاستماع - الحديث) لعينة (9 19) طالب وطالبـة

بالفرقة الثالثة بقسم الإعلام التربوي بكلية التربية النوعية بطنطا خلال العـام

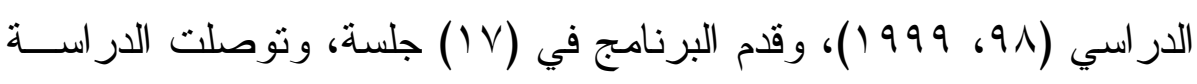
إلى وجود فروق لصالح طلاب المجمو عة التجريبية في مهــارتي الاســتماع و الحديث، وخلصت الدر اسة إلى أن البرنامج المقترح ذو فعالية في تحسـين •

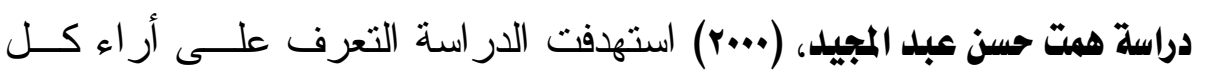
من: طلاب و أخصائي وموجهي الإعلام التربوي عن مدي الاســتفادة مــن الجانب الأكاديمي في الأداء المهني، و المشكلات و المعوقات التي تحد من هذه الاستفادة، و اعتمدت الدر اسة على المنهج الوصفي من خلال المسح الإعلامي لعينة من طلاب شعبة الإعلام التربوي بكلية التربية النوعية جامعة الزقازيق، وطلاب الفرقة الثالثة و الر ابعة تخصص صحافة و إذاعة وتليفزيــون، (Y I I) طالب وطالبة بالفرقة الثالثة، (90) طالب وطالبة بالفرقــة الر ابعـــة، (V7) أخصائي إعلام تربوي تخصص صحافة و إذاعــة مدرســية، (VT) موجهــا صحافة و إذاعة مدرسية بمحافظة الثرقية، وكثفت الدر اسة أن هناك تقــاوت في درجة استفادة طلاب الفرقة الثالثة و الر ابعة و الأخــصـئي مــن المــو اد الدر اسية في جو انب الحياة العملية، و الثقافة وحــب الاســتطلاع، ومعرفــة 
فعالية التلدييات المسرحية في إكساب طلاب الإعلام التربوي مهارات الععل المسرحي الأحداث الجارية، و التعامل مع الطلاب، و التدريب على فنون العمل، وكانت لصالح الخريج، و عن المشكلات التي تو اجه طلاب الإعلام التربــوي كثـرة المو اد العامة عن مو اد التخــصص القليلــة، عــدم وجــود أمـــاكن كافيــة للمحاضر ات، المو اد الدر اسية كلها نظرية غير عملية ووجود تــداخل فيمـــا بينها، ووجود مشكلات متعلقة بالتربية العملية، أما المشكلات التي يو اجههــا

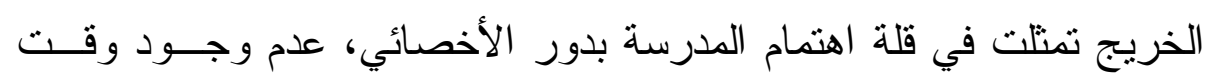
للتعامل مع الطلاب، قلة عدد الموجهين المتخصصين . دراسة أمل عبد الرحمن عيد، (ب..r) استهدفت الدر اسة التعــرف علــى فاعليــة استخدام الصحف في تتمية بعض مهار ات اللغة الإنجليزية لاى طلاب شعبة الإعلام التربوي بكليات التربية النوعية، وطبقت الباحثة اختبار مهار ات اللغة الإنجليزية على طلاب شعبة الإعلام التربوي وتوصلت إلى وجود فروق بين متوسطات درجات الطلاب في الاختبار القبلي و البعــدي لـصالح الاختبــار البعدي في مهارة القدرة على تخمين معاني الكلمات في سياق الجملة، ومهارة الضمائر سو اء كانت (إثـارة أو شخصية أو منعكسة)، ومهارة إدر الك الفكــرة

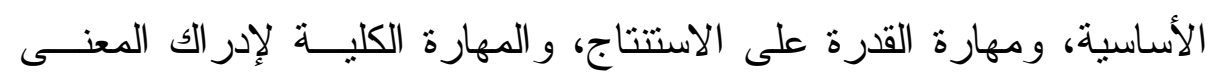
الضمني، مهارة استخدام المعجم، و المصطلحات الصحفية .

دراسة جمال مصطفي العيسوي، محمد محمود موسي (ب.+r) استهدفت الدر اسة التعرف

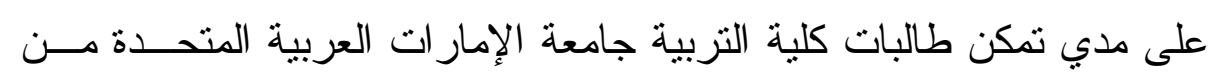
مهار ات الاتصال اللغوي، مهارة التحدث دون الاستماع، ودراسة الفروق في أدائهن لهذه المهار ات، و اعتمدت الدراسة على المنهج الوصفي التحليلي لعينة قو امها ( . . ب) طالبة من خمسة تخصصات : (الدر اسات الإســلامية، اللغــة العربية، الدر اسـات الاجتماعية، الرياضيات، العلوم) خلال الفصل الدر اسـي 


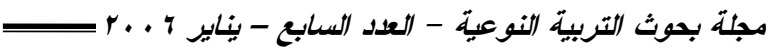

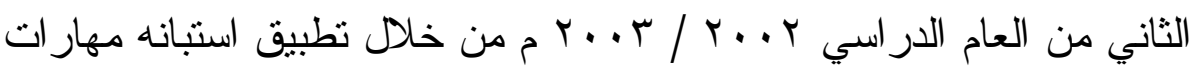
الاتصال اللغوي الثفهي، وبطاقة ملاحظة مهار ات الاتصال اللغوي الثفهي، وكثفت الدراسة عن إعداد قائمة بمهار ات الاتصال اللغوي الثفهي اللززمــة لطالبات كليات التربية، وجود انخفاض فـي مـستوي أداء الطالبــات لهـذذه المهار ات مع عدم وجود فروق بينهن وفقا لمتغير التخصص . دراسة راشد محمد عطية أبو صواوين، (ب.•r) استهدفت الدر اسة بناء برنامج مقترح لتتمية مهار ات التو اصل الثفوي (الاستماع، التحدث) لــدي طالبــات قـسم الإعلام التربوي المستوي الرابع بجامعــة الأقـصى، غــزة - فلـسطين . و اعتمدت الدر اسة على المنهج شبه التجريبي لعينة قو امها أربعــون طالبــة خلال العام الدراسي 999 / / . . . م م، وطبق الباحث: البرنامج المقتـرح، اختبار مهار ات التو اصل الثفوي، بطاقة ملاحظة مهار ات التحدث، وكـثـفت الدر اسة عن وجود فروق دالة إحصائيا لدي طالبات الإعلام التربــوي فـي التطبيق القبلي و البعدي لصالح التطبيق البعدي في مجموع مهار ات الاستماع وكل مهارة على حدة من مهــار ات الاســـماع (التميــز الــسمعي، الفهــم الاستتناجي، تحديد وصدق الرسالة المسموعة، منابعـــة الآراء المطروحــة)، مجمو ع مهار ات التحدث وكل مهارة من مهار ات التحدث على حــدة (تقـديم الموضوع، جودة الأفكار، الأسلوب، إدارة الموقف التو اصلي، ختم الحديث) . دراسة أحمد حسيز محمد حسن، (Y.•r) استهدفت الدر اسة التعرف على مـستوى الرضا التعليمي لاى طلاب الفرقة الر ابعة بقم الإعلام التربوي (الـصحافة، المسرح)، ببعض كليات التربية النوعية، ودر اسة الفروق بين الطلابب وفقـا لمتغير ات الدراسة، ودر اسة أثر وتقاعل هذه المتغيرات على الرضا التعليمي

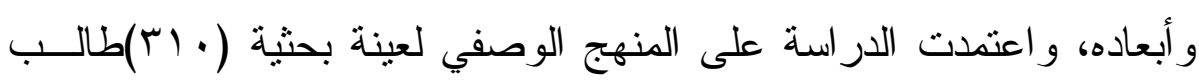


فعالية التلريبات المسرحية في إكساب طلاب الإعلام التربوي مهارات العدل المسرحي

وطالبة من (7) كليات للتزبية النوعية: (المنصورة، الدقي) لتمثــل الــشبة العامة إعلام تربوي، و أربع كليات أخرى تمنثل تخصص الصحافة و المسرح و هي (أشمون، طنطا، الزقازيق، العباسبة)، من خلال تطبيق مقياس الرضـــا التعليمي. وتوصلت الدراسة إلى: عدم وجود فروق دالة إحصائية بين الذكور

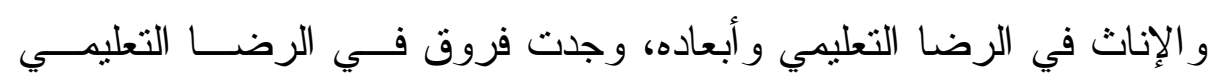
و أبعاده وفقا لمتغير التخصص، وجدت فروق دالة إحصائية في بعد الرضــا عن التدريب الميداني لصالح طلاب المدينة عن طلاب القرى، بينما لا توجد فروق في الرضا التعليمي الكلي وبعض أبعاده وفقا لمتغيــر مكــان إقامـــة الطلاب، وجدت فروق دالة إحصائية في الرضا التعليمي و أبعــاده - عــــا التدريب المبداني - وفقا لمتغير موقع الكلية، وجد تأثير وتفاعل دال إحصائيا لبعض المتغير ات الديموجر افية (التخصص: صحافة، مسر ح، مكـــان إقامــة الطلاب، موقع الكلية: العباسية، الزقازيق، الدقي) على الرضا التعليمي الكلي

$$
\text { وبعض أبعاده . }
$$

\section{تهقيسب على الدراسات السابقة :}

عرض الباحث الدر اسات السابقة في (7) در اسات عربية، اختلفت فيما بينها من حيث الموضوع و الهدف و المنهج فمنها ما اعتمد علـى المسـنهج (الوصــفي، التجريبي)، و اختلفت في عينتها وهى في الغالب من طلاب الفرقة الثالثة و الر ابعـــة بقسم الإعلام التربوي بكليات التزبية النوعية، و الخريجين "الأخصائيين"، و اختلفت في أدو اتها ما بين استبانات ومقابلات وبر امج لتتمية المهار ات، وقد كـشفت هـــهـ الدراسات عن فعالية البرامج المهارية لطلاب الإعلام التربوي، ووجود مجموعــة من المشكلات و أوصت بضرورة الاهتمام بطلاب الإعلام التربوي، على الرغم من أنه لا توجد أي در اسة أجريت على المقرر ات الدر اسية التي يدرسها طلاب الإعلام 


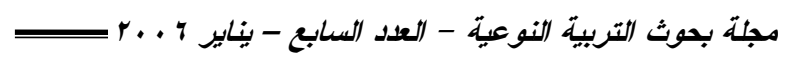

التزبوي، و هذه الدر اسة تغطى جانباً في هذا المجال . أوجه الإفادة هن الدراسات السابقة :

أفاد الباحث من عرضه لهذه الدراسات في تحديد مشكلة الدر اسة وأهميتهـــا و أهدافها ومصطلحاتها وفروضها وحدودها ومنهجها و عينتها، بناء مقياس مهار ات العمل المسرحي، بطاقة ملاحظة سلوكيات مهار ات العمل المسرحي .

\section{الإطار النظري للدراسة :}

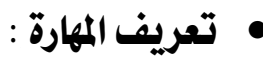

يختلف تعريف المهارة باختلاف أر اء الباحثن وتخصصاتهم المختلفة .

وقد جاء تعريف المهارة في اللغة في (المعجم الوجيز) "أن الثيء فيه وبــــ

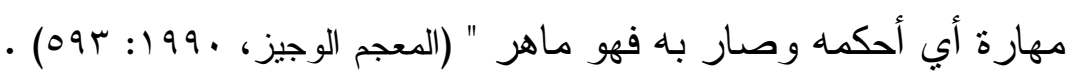

بينما جاء تعريف المهارة في الاصطلاح في (معجم المصطلحات التربويـــة المعرفة) "أنها الأداء السهل الدقيق القائم على الفهم لما يتعلمه الإنسان حركيا وعقليا

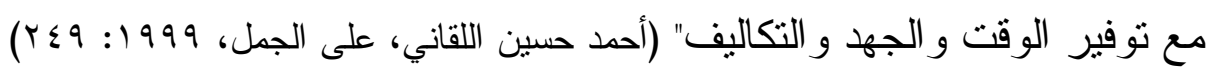
بينما يعرفها (قاموس إنجلش، و إنجلش) بأنها "قدرة على أداء أفعال حركيــة

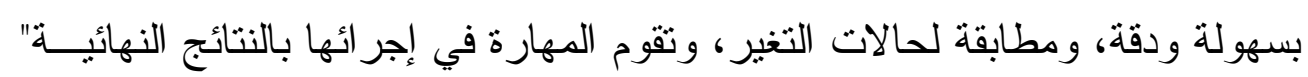
• (English, HiB\& English A.G.1984: 505)

ويعرفها (كمال الاسوقي) "بأنها سهولة ودقة وقدرة بدرجة مرتفعة تمكن الفرد من أداء فعل حركي معقد، وهي أداء سريع وكفه عقلي وجسمي يكون قد تعلمه،

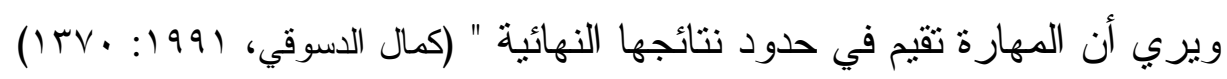
وتعرف المهارة في (قاموس التربية) بأنها "حذاقة تتمو بالتعلم وتكون حركية

أو لفظية أو عقلية أو مزيجا من أكثر من نوع (محمد على الخولي، 910 (17 1ـ) . 
 وتعرف المهارة في (قاموس الاجتماع) "بأنها تنظيم معقد للسلوك تطور من خلال عملية التعلم، و اتجاه نحو هدف معين أو تركز على نشاط محدد (محمد عاطف

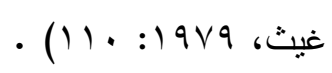

ويعرفها (جولدنسن) بأنها "قدرة عالية مكتسبة لأداء الأنشطة المعقدة بسهولة

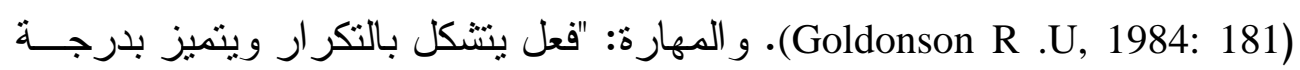

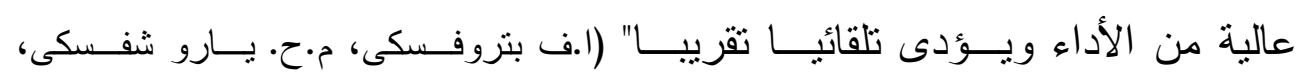
- (YKA: :)997

و المهارة: "أي شيء تعلمه الفرد ليؤديه بسهولة ودقة، وهى السهولة و الدقـــة

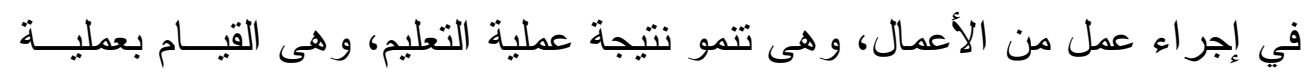

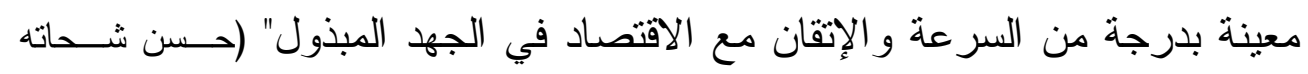

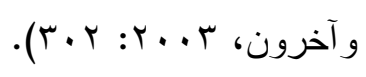

\section{خصائص المهارة : ت خ ت}

يمكن للباحث تحديد خصائص المهارة من خلال تحليله للتعريفات الـسابقة

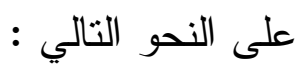
1- قدرة و أداء قائم على عملية الفهم .

ץ- المهارة تتمو بالتعلم أي أنها مكتسبة وتتم من خلال عملية التدريب . r- تحتاج إلى وقت وجهد وتكاليف . ع - تكون محدة بهدف يسعي المتعلم لتحقيقه . 0- المهارة قد تكون حركية أو لفظية أو عقلية أو حسية أو اجتماعية . 7- تقوم بنتائجها النهائية - وطالما ذلك - فإنه يمكن قياسها وملاحظتها . 


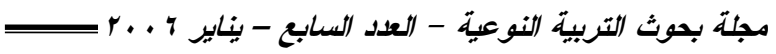

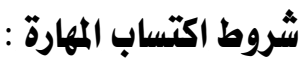

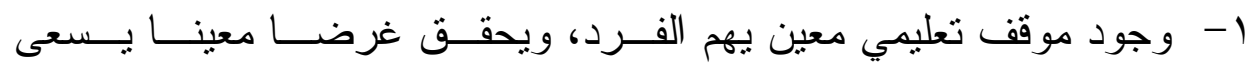

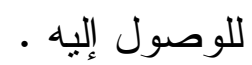

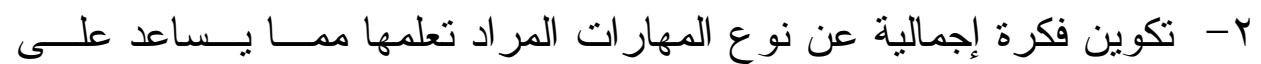
التغلب على ما قد يوجد من عقبات تعترض سبيل تعلمها ـ التهات r- أن يعرض المعلم على المتعلمين الطريقة المستخدمة في أداء المهارة بنفسه

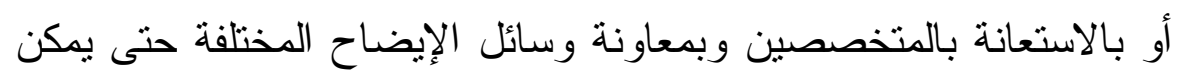

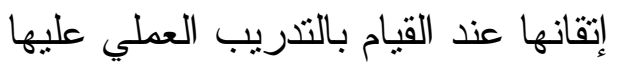

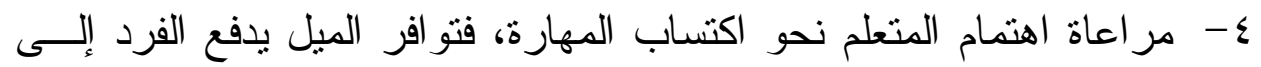

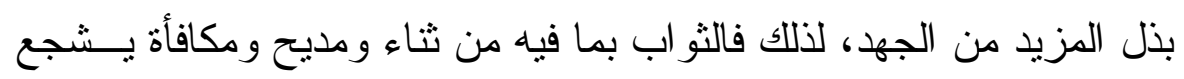
العمل، ويمكن لعملية اكتساب المهارة (SINGER, RN 1980) 0- النضج الجسمي و العصبي لدي المتعلم .

\section{• أهمية اكتساب مهارات العمل المسرحي لطلاب الإعلام التربوي :}

1- تتمي لدي الطلاب مهار ات العمل المسرحي المتمنلة في :

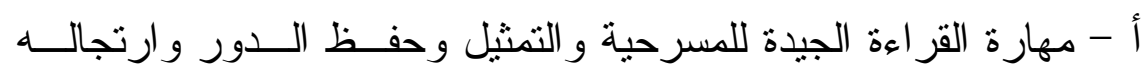

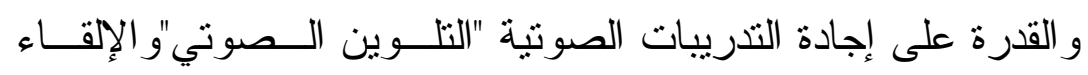

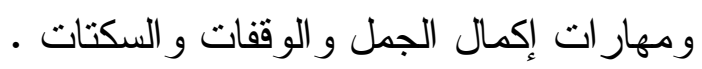

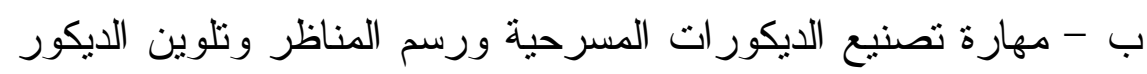

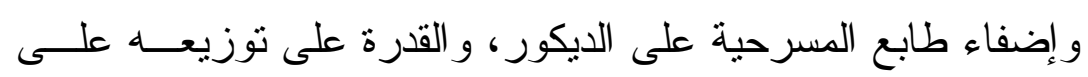

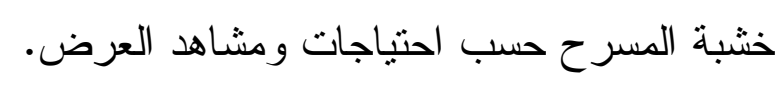
جـ- تحديد ملابس الثخصيات المسرحية وألو انها وفقا لطبيعة دور كل

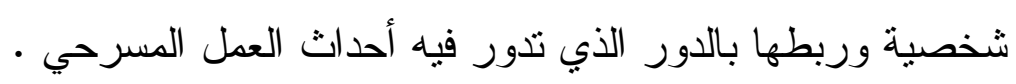


فعالية التلديبات المسرحية في إكساب طلاب الإعلام التربوي مهارات العمل المسرحي

د - تحديد الموسيقي و المؤثرات الصوتية في النص المسرحي وتحديـــ

نو عها وزمنها ودلالتها المـسرحية وتـسجيلها و اســتخدامها أثتـــاء

البروفات، و عند العرض و التحكم فيها وفي مستوي الصوت وتدرجه.

هـ - عمل الإضـاءة المسرحية و المؤثرات الــضئية وتحديـــد دلالتهـــا

اللونية وتحديد نوع المشهد ووقته.

و - و عمل ماكياج للشخصية المسرحية وفق أسـس علميـــة مدروســة

و التعرف على استخدام وسائل المكياج من لحى، شو ارب، حو اجــب

صناعية، كحل، و استخدام الإكسسوار ات المسرحية .

r- تساعد الطلاب في اكتساب مهار ات جسمية وحركية من خلال التعرف على

أوضـاع جسم الممثل و إتقان الحركات المسرحية و الإثـــار ات و الإيمـــاءات

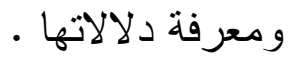

r- تساعد الطلاب في إكسابهم المهار ات العقلية و الذهنية دن خلال القدرة على التفكير و الخيال و التركيز و الانتباه في الدور، وبما ستكون عليه الثخــية المسرحية و الديكور ورسم المناظر المسرحية، و الملابـس، و الموســيقي، و الإضـاءة، و الماكياج و الإكسسو ار ات . ع- تتمي لدي الطلاب المهار ات الانفعالية من خلال ضبط المشاعر و التحكم في الانفعالات و المرونة وسعة الصدر و التسامح، فالعدـلـ المـسرحي يو اجــهـ الكثير من المشكلات منها ما يتعلق بفريق العمل وبالتــدريبات المـسرحية

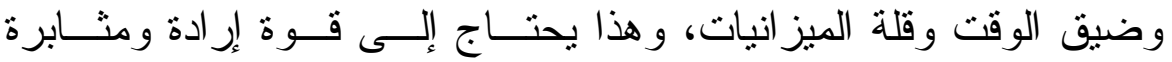
من الطلاب

ه- تتمي لدي الطلاب المهار ات الاجتماعية وحب العمل الجمــاعي و التمـسك بروح الفريق و المشاركة في الإعمال الجماعية وتحمل المسئولية من خلال اثتر الك الطلاب في مجموعات العمل (تمثيل، الديكور ورســم المنــاظر ، 


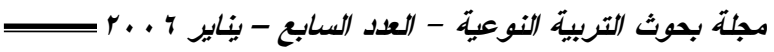

ملابس، موسيقي، إضـاءة مسرحية، ماكياج و إكسسوار) و إنجــاز الأعمــال

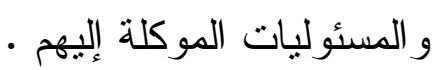

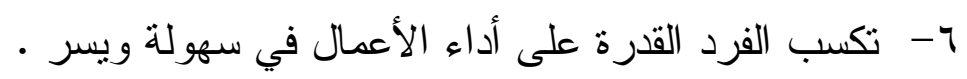
V- تمكن الفرد من القدرة على التواصل و التفاعل الاجتماعي مـــع الآخــرين وتقديم مقترحات وأر اء بشأن خطط العمل المسرحي والاسنماع و الإنصات

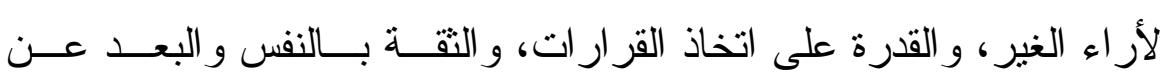
الانطو اء وعدم الخجل والقدرة على مواجهة الجمهور من خلال اثتـتز الك

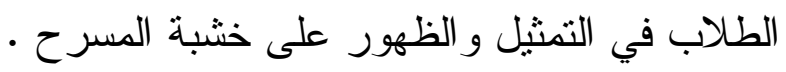
1- نساعد الطلاب على الانضباط و احتر ام مو اعيد البروفات المسرحية .

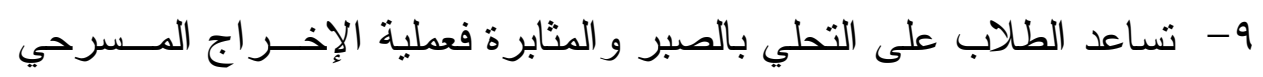
ليست بالسهلة، كما قد يخيل للبعض، ولكنها تحتاج إلى جهد ومشقة وخبرة علمية و عملية . بالية

\section{الإجراءات المنهجية للدراسة :}

\section{ا ـ منهج الدراسة :}

تعتمد الدر اسة على المنهج شبه التجريبي من خـــلال أســلوب المجموعـــة الو احدة، وقد أختار الباحث هذا الأسلوب وهذا المنهج للأسباب التالية : أ- طبيعة وهدف الدراسة، حيث أنها تهدف إلي التعرف على فعالية التـدريبات المسرحية في إكساب طلاب الإعلام التربوي بكلية التربية النوعية مهــار ات العمل المسرحي، وليس تجريب استر اتيجية تدريس معينة مقارنة باستر اتيجية

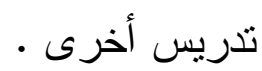

ب-هذه التدريبات يتلقاها الطلاب ككل من خلال در اسة مقـرر ورشـــة إنتــاج مسرحي المقرر عليهم در ستته، ولا يمكن تثبيت مجموعــة(ضــابطة) دون 
فعالية التلدريبات المسرحية في إكساب طلاب الإعلام التربوي مهارات العمل المسرحي

در اسة، وتعريض المجمو عة الثانية (التجريبية). للتذريبات من أجل البحث . ج-صغر حجم عينة المجتمع الأصلي و التي قو امها (7 1 1 ) طالب وطالبة وهــذا ما دفع الباحث لاستخدام المنهج شبه التجريبي ذي المجموعة الو احدة .

\section{r مينة الدراسة : مينة}

• عينة بسرية : من طلاب الفرقة الر ابعة بقسم الإعلام التربوي بكلية التربيــة

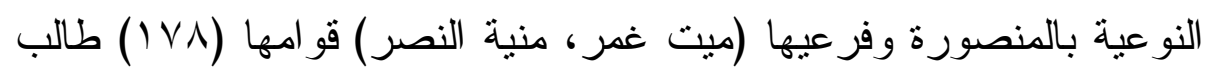
وطالبة من إجمالي (71 1 ا ) وهي موضحة بالجدول التالي :

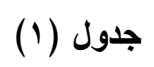

يوضح توزيع عينة الاراسة وفقا لمتغيرات النوع، المؤهل قبل الجامعي، نوع المشاركة، الكلية.

\begin{tabular}{|c|c|c|c|c|c|c|c|c|c|c|c|c|c|c|c|}
\hline \multirow{2}{*}{$\begin{array}{l}3 \\
3 . \\
7.3 \\
.3\end{array}$} & \multirow{2}{*}{ 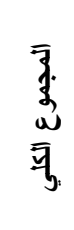 } & \multirow{2}{*}{ 享. } & \multicolumn{7}{|c|}{ نوع المشاركة } & \multicolumn{2}{|c|}{ الجؤهل قبل الجيل } & \multicolumn{2}{|c|}{ النوع } & \multirow[t]{2}{*}{$\overline{3}$} & \multirow[t]{2}{*}{ الكلية } \\
\hline & & & $\frac{3}{w}$ & $\bar{d}_{\substack{a \\
: \infty}}^{a}$ & 疍 & 弯 & 攉 & 录。 & $\frac{\sqrt{3}}{\pi}$ & $\frac{y}{2}$ & ? & 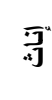 & 当 & & \\
\hline \multirow{2}{*}{7} & \multirow{2}{*}{ v. } & $r v$ & $r$ & $\varepsilon$ & 0 & 1. & $v$ & $v$ & $r$ & \multirow{2}{*}{$\leqslant 4$} & \multirow{2}{*}{$r \varepsilon$} & iv & $r$. & \multirow{2}{*}{$r$} & \multirow{2}{*}{ المنصورة } \\
\hline & & rr & $r$ & $\varepsilon$ & $r$ & 0 & $v$ & 1. & $r$ & & & 11 & rr & & \\
\hline \multirow{2}{*}{1} & \multirow{2}{*}{$\Lambda}$. & $\varepsilon$. & $r$ & 0 & $r$ & $\varepsilon$ & $\wedge$ & ir & $\varepsilon$ & \multirow{2}{*}{ rV } & \multirow{2}{*}{ ir } & rq & 11 & \multirow{2}{*}{$r$} & \multirow{2}{*}{ ميت غمر } \\
\hline & & $\varepsilon$ & r & $\varepsilon$ & $r$ & 9 & 9 & ir & $r$ & & & $r$. & 1. & & \\
\hline 1 & rA & $r \wedge$ & $r$ & $r$ & $r$ & $r$ & $v$ & 9 & r & r4 & $r$ & ir & 17 & 1 & منية النصر \\
\hline$\wedge$ & $1 v \wedge$ & $1 V A$ & ir & 19 & 17 & $r \wedge$ & rA & Or & ir & 99 & rq & 99 & va & 0 & المجموع \\
\hline$\wedge$ & $1 \vee \wedge$ & IVA & ir & 19 & 18 & rA & rی & or & ir & \multicolumn{2}{|c|}{$1 \mathrm{rA}$} & \multicolumn{2}{|c|}{ IVA } & D & مج الكلي \\
\hline
\end{tabular}

- وقد تم تقسيم عينة الطلاب المبينة بالجدول وفقا لر غبة الطالب ومشاركته في العمل المسرحي، ووفقا لاحتياجات التدريبات المسرحية .

*) المؤهل قبل الجامعي يقاس على مستوي الذكور فقط حيث أن كل الإناث ثانوية عامة، أما الذكور فهم مقـسمين

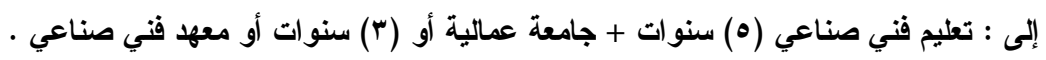


مجلة بحوث التربية النوعية - العدد السابع - يناير r...r.

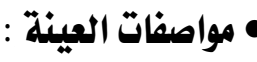

أ- تشتمل على الذكور و الإناث معا .

ب- استبعاد الطلاب الراسبين، و الطلاب المتكــرر غيـابهم عـن حـضور

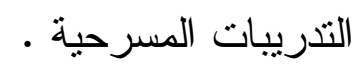

rـأدوات الدراسة : (وهي من إعداد الباحث)

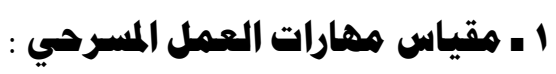

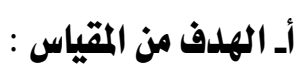

قياس مهار ات العمل المسرحي لدي طلاب الإعــلام التربـــوي ودراســـة الفروق بينهم وفقا لمتغير ات الدراسة.

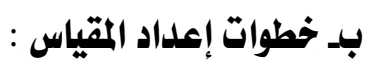

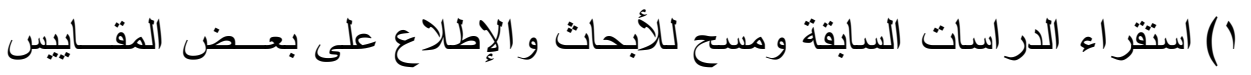

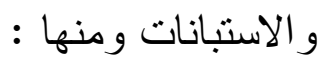

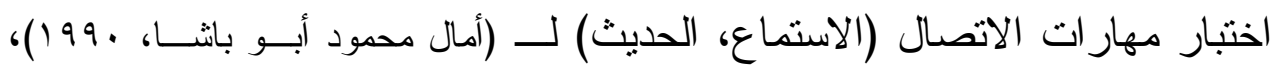

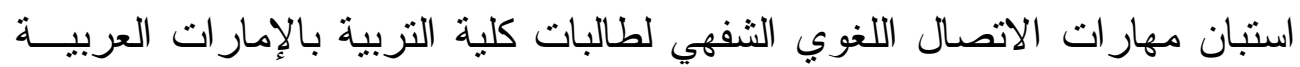

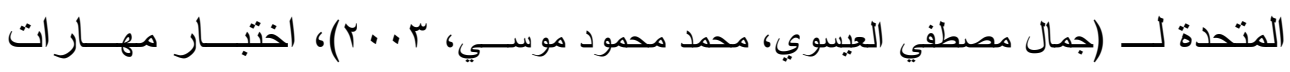

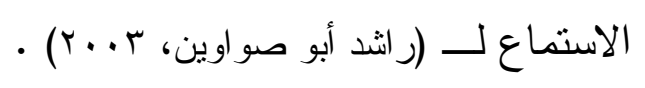

r) حدد الباحث مهار ات العمل المسرحي في (^) أبعاد رئيسية، يحتوي كلا منها على مجمو عة من المهار ات الفرعية وهي كالتالي :

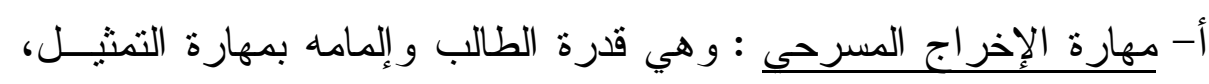
الديكور ورسم المناظر، الملابس المسرحية، الإضـاءة، الموسيقي، الماكياج

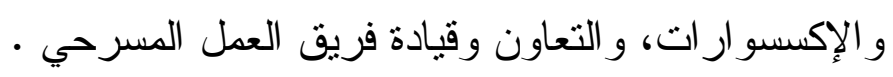


فعالية التلدريبات المسرحية في إكساب طلاب الإعلام التربوي مهارات العمل المسرحي

ب - مهارة التمثثل : هي قدرة الطالب على قر اعة المسرحية قــر اءة جيــدة وتحليلها وحفظ الأدوار و الخيال و التخيل ومعايـشة الثخــصية وتقليـــدها و الملاحظة و الانتباه و التزكيز و الإحساس بالدور ، و إجادة التدريبات الصوتية و الحركية وتشمل العبار ات من (1 - 10 ) بالمقياس • جـ - مهارة الديكور ورسم المناظر المسرحية : هي قدرة الطالـب علـى تصنيع الديكور ودهانه ورسم المناظر ، و إضفاء طــابع المسـرحية علـى وهى الديكور وتوزيعه على خثبة المسرح وفقا لاحتياجات العرض المسسرحي

$$
\text { وتحديد وقت وزمن المنظر وتشمل العبار ات من (T ( ا (Y) }
$$

د - مهارة الملابس المسرحية : هي قدرة الطالـب علـى تحديــــ ملابـس الثخصبات المسرحية وفقا لطبيعة دور ها وتحديد لونهــا، و القــدرة علــى تغبيزر ها وفقا لمر احل تطور الثخصية، وربطها بالعصر الذي تـدور فيــه

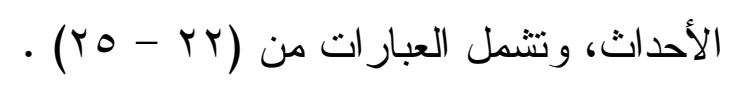

هـ- مهارة الموسيقي و المؤثر ات الصوثية : هي قدرة الطالب على تحديـــ

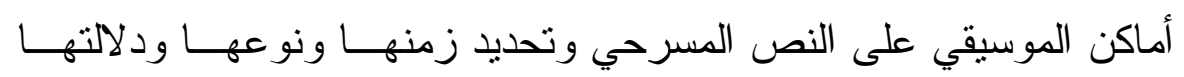
وتسجيلها على شر ائط كاسيت و استخدامها وقــت البروفــات المـسرحية و التحكم في مستوي الصوت الموسيقي، وتحديد المؤثزات الصوتية وزمنها ودلالتها وتوظيف ذلك بما يخدم العرض المسـرحي، وتـشمل العبــار ات

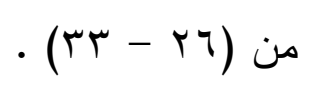

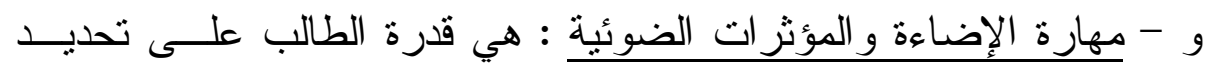

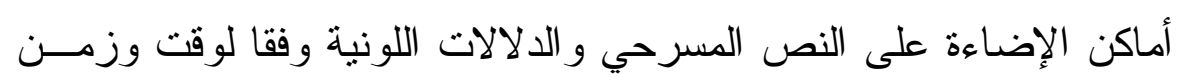

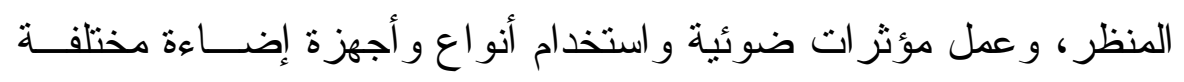
أثتاء التدريبات، وتشمل العبار ات من (ع - و ب) . 
مجلة بحوث التربية النوعية - العدد السابع - يناير r ..r بـ

ز - مهارة الماكياج و الإكسسوار ات المسرحية : هي قدرة الطالب على عمل

ماكياج للشخصيات المسرحية وفقا لطبيعة الدور المسرحي من خلا أدو ات اتليه

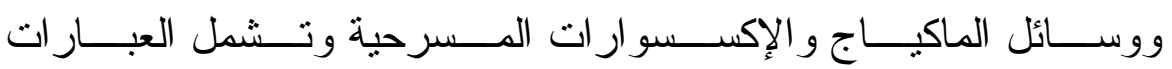

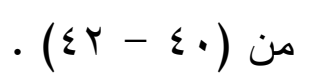

ح - مهارة التعاون: هي قدرة الطلاب على التعاون و التفاعل مع بعـضهم

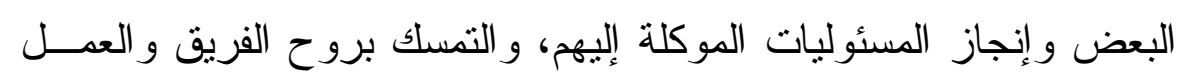

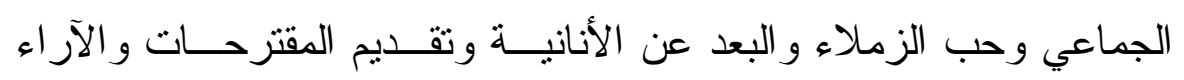

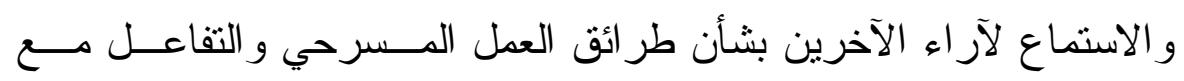

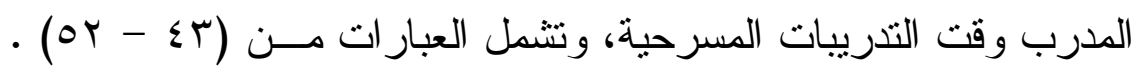

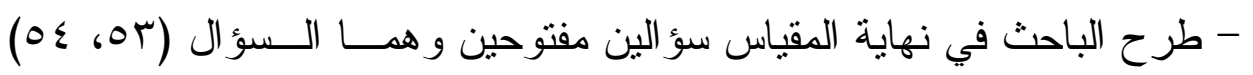

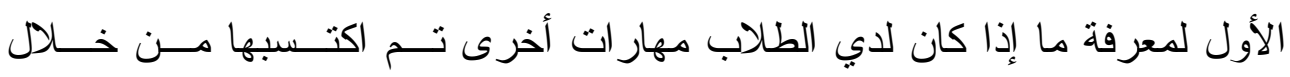

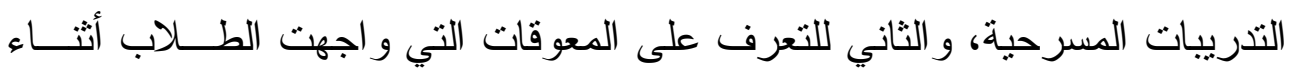
التذريبات المسرحية وتؤثز على درجة اكتسابهم لمهار ات العمل المسرحي .

r) عرض الباحث المقياس في صورته الأولية على (T) محكمين (*) في مجــال

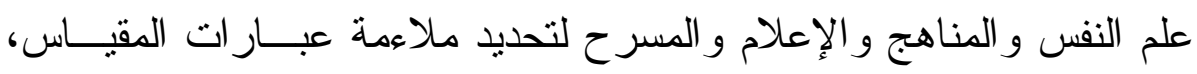
و إضافة أي عبار ات أو أبعاد أخرى للمقياس، وجاءت واستجاباتهم كالتـالي : عدم كتابة كلمة مهارة في بداية كل عبارة، استخدام التذريج الرباعي و استبعاد الدرجة الصفرية، استخدام بطاقة ملاحظة، لملاحظة سلوكيات مهار ات العمل بل بله

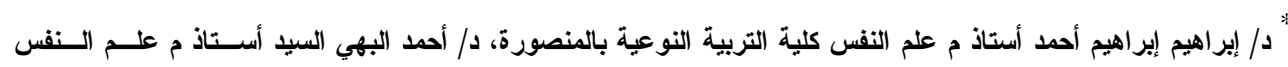

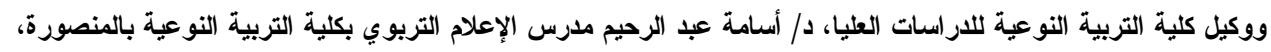

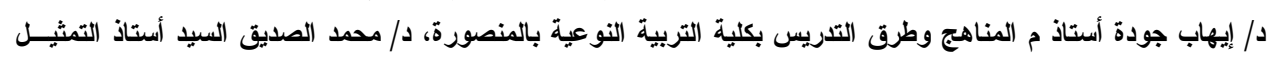

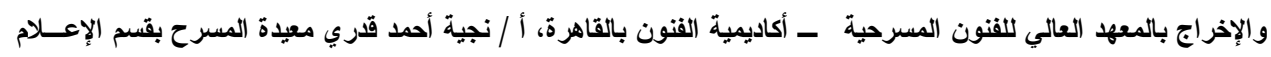
التربوي بكلية التربية النوعية بالمنصورة .

\section{roq}


فعالية التلديبات المسرحية في إكساب طلاب الإعلام التربوي مهارات العمل المسرحي المسرحي إلى جانب المقياس، الاكتفاء بدر اسة هذه المهار ات مع عدم إضافة مهار ات أو عبار ات أخري، ومن ثم صارت عبار ات المقياس (Yro عبـارة تشير كل منها إلى مهارة فر عية تتدر ج تحت (^) أبعاد .

جـ تعليهات المقياس :

•وضع عبارة للاسترشاد بها لتعريف الطلاب نحو إجابته على المقياس منل:

$$
\text { العبارة }
$$

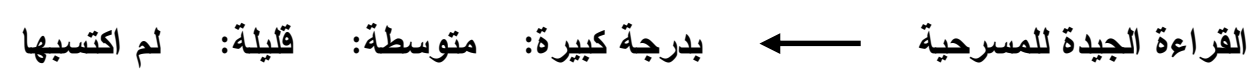
• كتابة البيانات الثخصية للطالب :

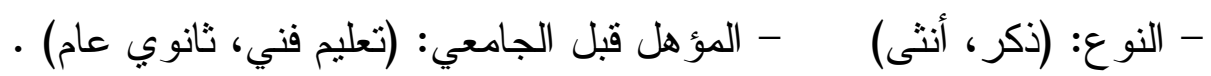
- نوع المشاركة:(تمثيل، ديكور، ملابس، إضاءة، موسيقي، ماكياج و إكسسوار) - الكلية : المنصورة (مبت غمر، منية النصر) .

دـ مفتاح التصحيح :

استخدم الباحث طريقة ليكرت لقياس الاتجاه في تقدير درجــات المقيــاس، و تتحدد طريقة التصحيح بناء على إجابة المبحوث، حيث تحــصل الإجابــة علــى اكتساب المهارة بدرجة كبيرة على أربع درجات، وبدرجة متوسطة علـى ثـلاث درجات، وبدرجة قليلة على درجتين، ولم اكتسبها على درجــة و احــدة، و اســتبعد الباحث الدرجة الصفرية لأنها تعني انعدام المهارة عند الفرد وهذا غير صحيح . أما الدرجة الكلية لمقياس مهار ات العمل المسرحي فهـي عــدد مفـردات

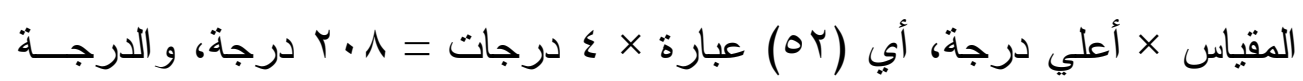

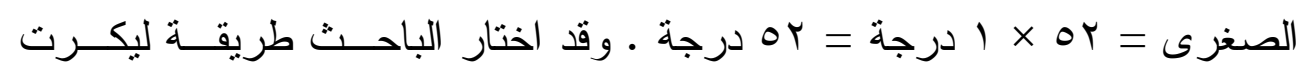
للأسباب التالية : 


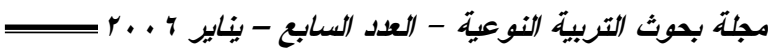

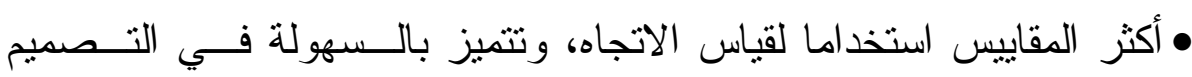

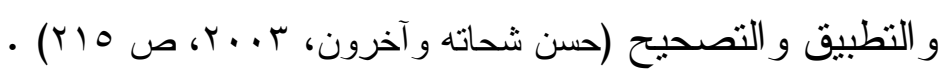

•تعطي تقدير ادقيقا لمدي مو افقة أو رفض المبحوث بناءاً على التدريج الذي يتبع كل بند من بنود المقياس، وتسمح بتحليلات أكثر دقة لمعنـي الاتجـــاه

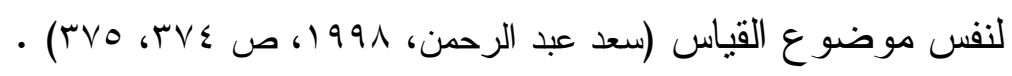

هـ ـ إجراءات تطبيق المقياس :

اـ قام الباحث بتطبيق المقياس على طلاب العينة ( I V ) كقياس قبلي، أي

قبل إجر اء التدريبات المسرحية للوقوف على ما لاي الطلاب من مهار ات مسرحية سابقة خاصة وأن طلاب الإعلام التربوي درسو ا خمسة مقرر ات مسرحية ســابقة على مقرر مادة ورشة الإنتاج المسرحي خلال سنوات در ستهم الأربعة بالكلية، ولم يكتق بالسؤال الذي طرحه عليهم عن : هل لديكم خلفية عن المسرح ؟ وهل قدمتم

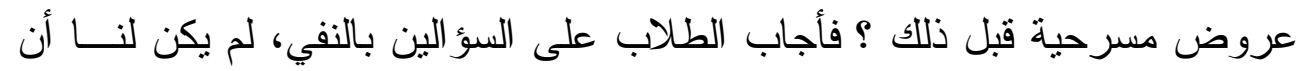
قمنا بالتمثيل قبل ذلك ولدينا خلفية نظرية بسيطة عن المسرح، وذللك للوقوف على لـى بلى بلى

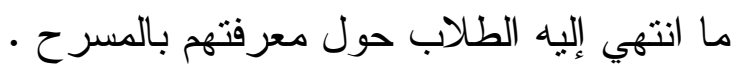

r- طبق الباحث المقياس بطريقة جماعية ومن خلا المقابلة الثخصية .

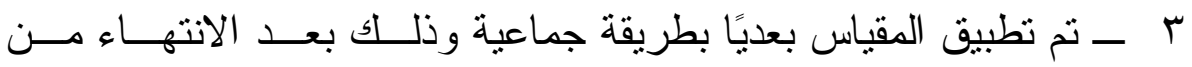

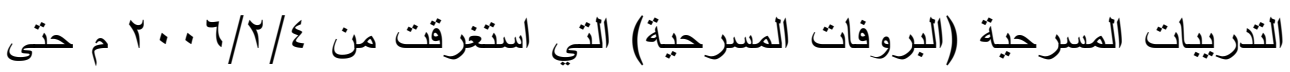

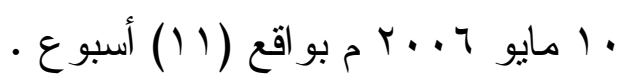


اختار الباحث عينة عشو ائية من طلاب الفرقة الر ابعة بقسم الإعلام التربوي بكليات التزبية النوعية بالمنصورة وفرعيها (ميت غمر، منية النصر) قو امها (.0)

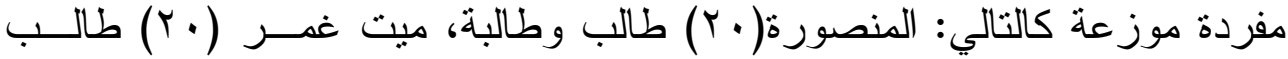
وطالبة، منية النصر ( • () طلاب لعمل اختبار الثبات وهي مبينة بالجدول التالي :

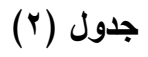

توزيع عينة ثبات مقياس مهارات العمل المسرحي وفقا لمتغير ات الدراسة ن= ( • ه) طالب وطالبة

\begin{tabular}{|c|c|c|c|c|c|c|c|c|c|c|c|}
\hline \multirow{2}{*}{ 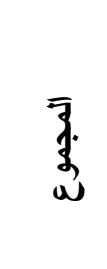 } & \multicolumn{7}{|c|}{ المجموعة التي يشارك فيها الطالب } & \multicolumn{2}{|c|}{ المؤهل قبل } & \multicolumn{2}{|c|}{ النوع الن } \\
\hline & $\frac{\sqrt[3]{3}}{\pi}$ & 辛: & 疍 & ד] & 章 & 录 & 桪。 & $\frac{y}{2}$ & : & 哥 & 资 \\
\hline o. & $v$ & $r$ & 9 & 0 & v & $\wedge$ & $1 \leqslant$ & ro & 10 & rr & $r \wedge$ \\
\hline$\% 1 \ldots$ & $\% 1 \leq$ & $\% 7$ & $\% \backslash r$ & $\% 1$. & $\% 1 \leq$ & $\% 17$ & $\%$ \% & $\% v$. & $\%$ \%. & $\%$ \% & $\% \circ 4$ \\
\hline
\end{tabular}

وتم حساب ثبات المقياس بطريقتين :

\section{أ - م طريقة الاتساق الداخلي : - م}

لحساب معامل ارتباط "ألفا كرونباخ" لكل بعد من الأبعاد و الدرجـــة الكليــة للمقياس، وكانت على النحو التالي : مهارة التمثيل (T/, •)، مهارة إعداد وتجهيـز

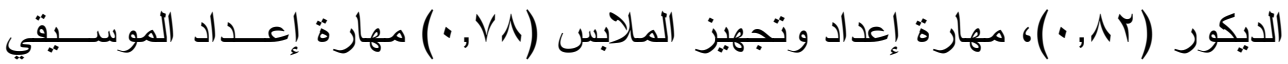

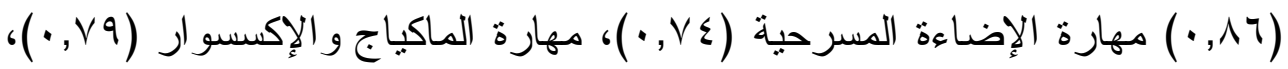

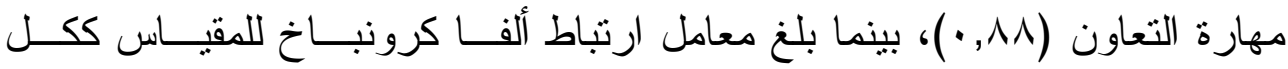

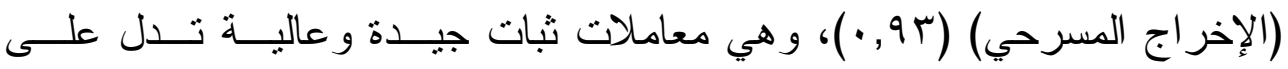




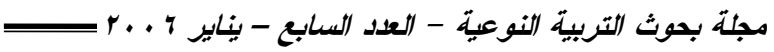

\section{ب - معامل ارتباط بيرسون :}

تم حساب معامل ارنباط بيرسون المفردة بالبعد، الأبعاد مع بعضها، الأبعاد

\section{بالدرجة الكلية للمقياس كالتالي :}

ا- معامل ارتباط بيرسون المفردة بالبعد، ويمكن توضيح نتائجه في الجدول التالي:

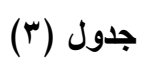

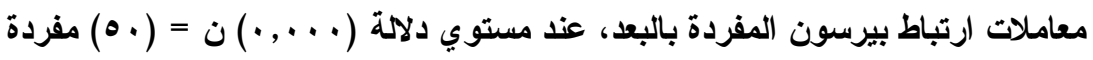

\begin{tabular}{|c|c|c|c|c|}
\hline معامل ارتباط المفردات & المفردات & من : المفردات & 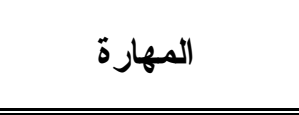 & م \\
\hline 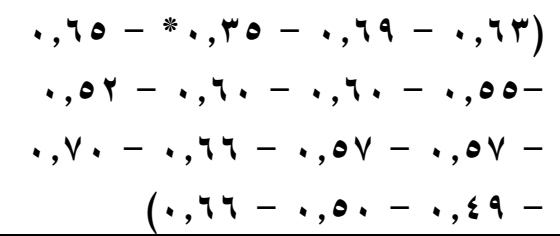 & 10 & $10-1$ & التمثيل & 1 \\
\hline $\begin{array}{r}-,, 74-\cdot, \vee 1- \\
(\cdot, 4 q-\cdot, \wedge 1) \\
(, \wedge 1-\cdot, \vee r\end{array}$ & 7 & $11-17$ & الايكور & $r$ \\
\hline$(\cdot, \wedge r-\cdot, \wedge \varepsilon-\cdot, \neg \vee-\cdot, \vee \vee V)$ & $\varepsilon$ & $r \Delta-r r$ & الملابس & r \\
\hline $\begin{array}{r}-, \neg-\cdot, \curlyvee \wedge-\cdot, \wedge \varepsilon-\cdot, \vee \wedge) \\
(\cdot, \vee \curlyvee-\cdot, \curlyvee \neg-\cdot, \vee \vee-\cdot, \vee \uparrow\end{array}$ & $\Lambda$ & q & الموسيقي & $\varepsilon$ \\
\hline 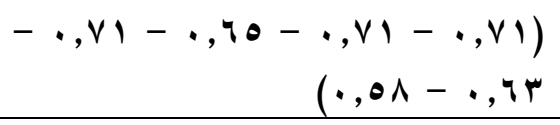 & 7 & $r q-r \varepsilon$ & الإضاءة & $\bullet$ \\
\hline$(\cdot, \wedge \neg-\cdot, \wedge \leq-\cdot, \wedge \perp)$ & $r$ & $\varepsilon r-\varepsilon$ & الماكياج و الإكسسوار & 9 \\
\hline 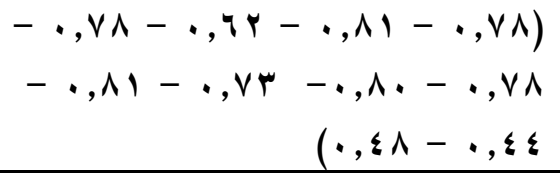 & $1 \cdot$ & $\Delta r-\varepsilon r$ & التعاون & V \\
\hline
\end{tabular}

من الجدول السابق يتضح أن جميع المفردات مرتبطة بالأبعــاد، ودرجــة

الارتباط جيدة و عالية .

" المفردة رقم (ץ) فقط بالمقياس دالة عند ( ( . , .) ) 
בب فعالية التلـييات المسرحية في إكساب طلاب الإعلام التربوي مهارات الععل المسرحي بـ ץ- معامل ارتباط بيرسون الأبعاد مع بعضها، و الأبعاد بالدرجة الكليــة : ويمكـن توضبح ذلك في الجدول التالي :

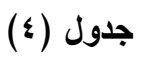

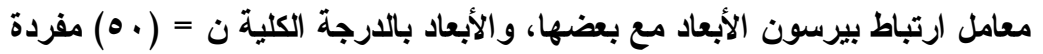

\begin{tabular}{|c|c|c|c|c|c|c|c|c|}
\hline 牙 & $\begin{array}{l}\bar{y} \\
\bar{y}\end{array}$ & :3a" & दू. & 高 & ఫุ: & 浔 & p & p \\
\hline & & & & & & $\begin{array}{l}\cdot, \circ \vee r \\
., \ldots\end{array}$ & الديكور & 1 \\
\hline & & & & & $\begin{array}{l}\cdot, 0 \wedge 1 \\
\cdot, \cdots\end{array}$ & $\begin{array}{l}\cdot, 09 . \\
\cdot, \cdots\end{array}$ & المهلابس & $r$ \\
\hline & & & & $\begin{array}{l}\cdot, \leqslant \Lambda . \\
\cdot, \ldots\end{array}$ & $\begin{array}{l}., 0 \cdot \Lambda \\
\cdot, \cdots\end{array}$ & $\begin{array}{l}\cdot, \leqslant 00 \\
\cdot, \cdots 1\end{array}$ & الموسيقي & $r$ \\
\hline & & & $\begin{array}{l}\cdot, \text { or } \wedge \\
., \ldots\end{array}$ & $\begin{array}{l}\cdot, r \leq . \\
\cdot, \cdot 17\end{array}$ & מ., . . . & $\begin{array}{l}\cdot, \leqslant 4 \wedge \\
\cdot, \cdots 1\end{array}$ & الإضاءة & $\varepsilon$ \\
\hline & & $\begin{array}{l}\cdot, \uparrow \vee 4 \\
\cdot, \ldots\end{array}$ & $\begin{array}{l}\cdot, \leqslant 99 \\
\cdot, \cdots 1\end{array}$ & $\begin{array}{l}\cdot, \leqslant \wedge \bullet \\
\cdot, \ldots\end{array}$ & $\begin{array}{l}\cdot, \leqslant \leqslant V \\
\cdot, \ldots\end{array}$ & $\begin{array}{l}\cdot, \varepsilon \wedge \varepsilon \\
\cdot, \ldots\end{array}$ & الماكياج و الإكسسوار & 0 \\
\hline & $\begin{array}{l}\cdot, \varepsilon \otimes \wedge \\
\cdot, \cdots 1\end{array}$ & $\begin{array}{l}\cdot, r \circ q \\
\cdot, .7 q\end{array}$ & $\begin{array}{l}\cdot, r \circ r \\
\cdot, \cdot \operatorname{rr}\end{array}$ & $\begin{array}{l}\cdot, r \leq \varepsilon \\
\cdot, \wedge \wedge\end{array}$ & $\begin{array}{l}\cdot,|v| \\
\cdot, r m q\end{array}$ & $\begin{array}{l}\cdot, r q r \\
\cdot, r q\end{array}$ & التعاون & 7 \\
\hline $\begin{array}{l}., 7 \cdot 7 \\
., \ldots\end{array}$ & $\begin{array}{l}\cdot, \text {, vrr } \\
\cdot, \ldots\end{array}$ & $\begin{array}{l}., 791 \\
., \ldots\end{array}$ & $\begin{array}{l}\cdot, \vee 01 \\
\cdot, \cdots\end{array}$ & $\begin{array}{l}\cdot, \vee \cdots \\
\cdot, \cdots\end{array}$ & $\begin{array}{l}\cdot, \mathrm{V} r \mathrm{~V} \\
\cdot, \cdots\end{array}$ & $\begin{array}{l}\cdot, \wedge 1 \\
\cdot, \ldots\end{array}$ & المهارة الكلية & $V$ \\
\hline
\end{tabular}

ارتبطت الأبعاد مع بعضها البعض وكانت معساملات الارنبــاط منوســة وجيدة، ماعدا مهارة التعاون فهي لم تزتبط بمهار ات (الديكور، المالابس، الإضاءة)، فهي غير دالة إحصائيا، في حين أن معامل ارتباط هذه المهارة بكل مــن مهــارة 
مجلة بحوث التربية النوعية - العدد السابع - يناير r ..r بـ

التمثيل، و الموسيقي ضعيف ولكنها دالة إحصائيا في حين ارتبطت هــذه المهــارة بمهارة الماكياج و الإكسسو ار ولكن معامل الارثباط متوسط وهذا يدل علــى ثبــات المقياس، في حين أن الطلاب قبل تطبيق التدريبات لم يكن لايهر مهــارة التعــاون

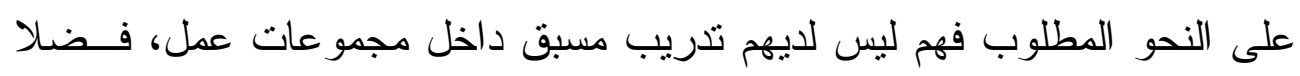
عن أن مهارة التعاون ليست هي المهارة الأساسية المستهدفة لقياس فعالية التذريبات

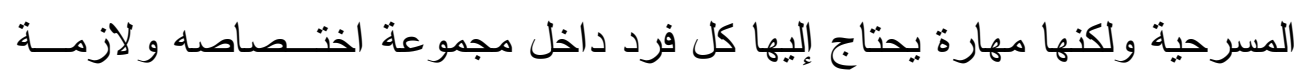
لقياس فعالية التدريبات المسرحية .

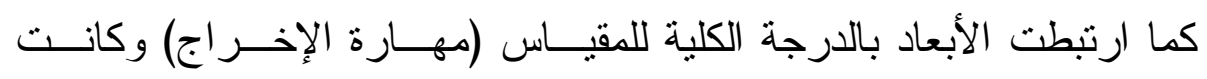

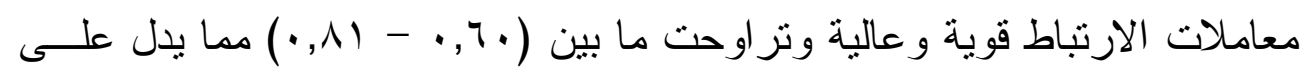

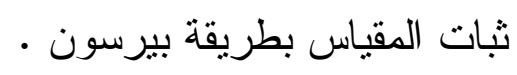

\section{rم بطاقة ملاحظة سلوكيات مهارات العمل المسرحي :}

(أ) الهدف من بطاقة الملاحظة :

1 - الحصول على معلومات وبيانات صحيحة ودقيقة عن سـلـوكيات مهـار ات

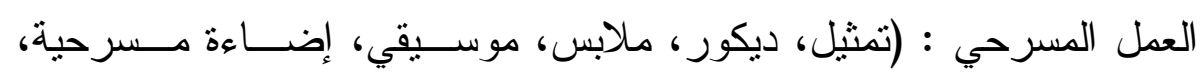

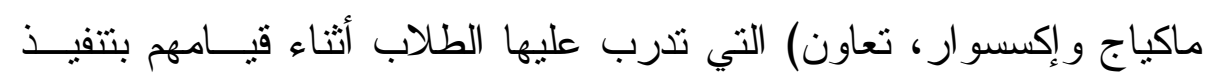

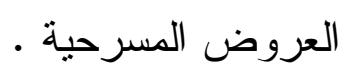
r- التحقق من صحة الفروض الأربعة الأخيرة (9 - r I ) .

\section{(ب) إجراءات القيام بالملاحظة :}

1-تحديد الهدف من بطاقة الملاحظة.

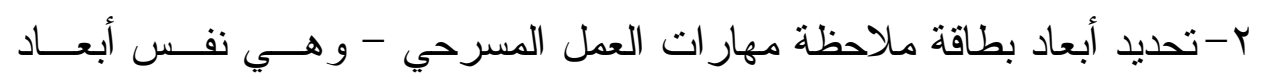
مقياس مهار ات العمل المسرحي الثمانية . 
فعالية التلدرييات المسرحية في إكساب طلاب الإعلام التربوي مهارات العمل المسرحي ــ r- استقر اء الدر اسـات السابقة ومسح الأبحاث في المجال، و الإطلاع على بعض بطاقات الملاحظة ومنها : بطاقة ملاحظة سلوكيات المهــار ات الاجتماعبــة

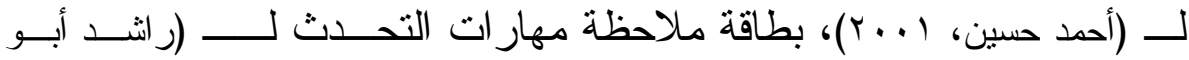

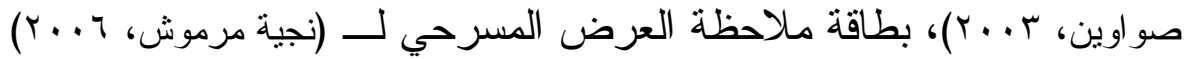
؟- وضع مجموعة من المفردات (العبار ات) لكل بعد من أبعاد بطاقة الملاحظة، يمكن للماحظ من خلالها ملاحظة سلوكيات مهار ات العمل المسرحي لـدى الطلاب وهى كالتالي : أ - مهارة التمثيل : هى قدرة الطلاب الممثلين على حفظ الأدوار و الإحساس بالدور ، و التلوين الصوتي و إكمال الجمل و الكلمــات و إجــادة الـسكتات و الوقفات، و الحركات المسرحية و التفاعل على خثبة المسرح، وتـشمل

$$
\text { العبار ات من (1 - م) بالبطاقة . }
$$

ب - مهارة الديكور : هي قدرة الطلاب على توظيف الديكور ليتتاسب مـع طبيعة المسرحية، وتوزيعه على خثبة المسر ح طبقا للمــشاهد، وتـشمل

$$
\text { العبار ات من (q - r I ) بالبطاقة . }
$$

جـ- مهارة الملابس : هي قدرة الطلاب على استخدام الملابس المـسرحية أثتاء العرض المسرحي ومدي مناسبتها للشخصية وتغيرهــــا وارتباطهــا بالثخصية ومكان الأحداث، وتشمل العبار ات من (r IV - IV) بالبطاقة . د - مهارة الموسيقي : هي قدرة الطلاب على استخدام الموسيقي ونوظيفهـا لخدمة المشاهد الدر امية واستخدام أنو اع مختلفة منها ومناسبتها للحسـوار و المشهد، و التحكم في مستوي الصوت الموسيقي وزمنه، و عمل المؤثزات الصوتية، وتشمل العبار ات من (1 I - بr) بالبطاقة. هـ- مهارة الإضـاءة المسرحية : هى قدرة الطلاب على استخدام الإضـــاءة المسرحية و المؤثزات الضوئية في العرض وتوظيفها لخدمــة المــــاهد 


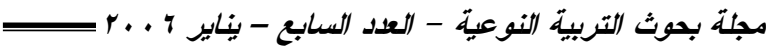

الدر امية، و استخدام أنو اع و أجهزة إضـاءة مختلفة، وتشمل العبار ات مــن

$$
\text { - بالبطاقة (rV_rs) }
$$

و - مهارة الماكياج و الإكسسو ار : هي قدرة الطلاب على عمـلـ ماكيــاج و استخدام الإكسسوار ات المسرحية للممثلين ومدي مناســبتها و اســتخدام

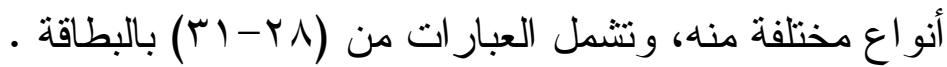
ز - مهارة التعاون : هي قدرة الطلاب على التعاون مع بعـضهم الــبعض كفريق عمل قبل وأثتاء العرض المسرحي، ونشمل العبار ات من (بr م م) بالبطاقة م

ه-ر اعى الباحث أن تكون أبعاد بطاقة الماحظة ومفرداتها مطابقــة لمقيــاس مهار ات العمل المسرحي، وذلك لتحقق الماحظين من مدي اكتساب الطلاب

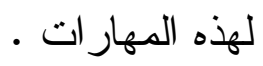

\section{(ج) تعليمات بطاقة الملاحخةة :}

- تعريف الملاحظ بالهدف من الدر اسة، و الهدف من بطاقة الملاحظة لتكتمل الصورة عما يمكن ملاحظته، وتعريفه بطريقة الإجابة على بنود المالاحظــة مــن خلال عبارة للاسترشاد بها . الدرجة

$1-r-r$ مثنال : حفظ الطلاب للأدوار المسرحية - كتابة بيانات الملاحظ الثخصية : (الاسم، النوع) - كتابة تعليق عام على العرض المسرحي بعد مشاهدته .

(د) مثتاح التصحيح (1)

استخدم الباحث طريقة ليكرت في تقدير الدرجات (التدريج الثالاتي) فتحصل الإجابة يكتسب الطلاب المهارة بدرجة كبيرة على ثلاث درجات، ويكتسبها بدرجة 
فعالية التلريبات المسرحية في إكساب طلاب الإعلام التربوي مهارات العمل المسرحي ـــ

$$
\text { متوسطة على درجتين، ولم يكتسبها على درجة و احدة . }
$$

أما الدرجة الكلبة للبطاقة فهي تقدر بعدد مفردات البطاقة × أعلــي درجــة

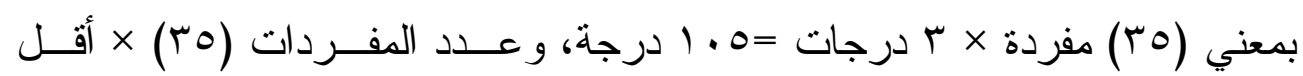
درجة = هب درجة، أي أن درجات البطاقة تقع ما بين (0 ـ 1 - هب) .

\section{(هـ) إجراءات تطبيق بطاقة الملاحظة :}

• يتم تطبيق بطاقة الملاحظة أثناء أداء العروض المسرحية، وبشكل إجمــالي

$$
\text { على طلاب كل مجموعة . }
$$

• حدد الباحث (0) ملاحظين إلى جانــب ملاحظتــه للبعــد عـن المبــول و الأهو اء الذاتية .

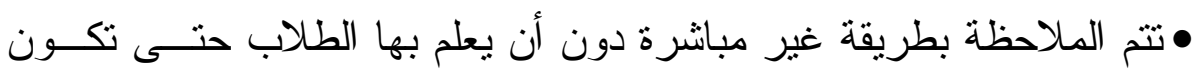
استجاباتهم نحو العروض تلقائية، ومن ثم عدم الانشغال وشعور هم بـــــم تحت الملاحظة، فينشغلو ا بالملاحظين دون العرض المسرحي • •زمن الملاحظة : هو زمن العرض المسرحي (هץ - . ب) دقيقة . • مكان الماحظة : مكان العرض بكل كلية (المدرج) • • القائم بالماحظة(ع) من الملاحظين المتخصصين في مجال المسرح مع(ب) من غير المتخصصين، و العاملين من أعضاء هيئة التذريس بقسم الإعــلام التزبوي بكلية التربية النوعية بالمنصورة وفر عيها بميــت غمــر ومنيــة النصر ، وذلك ليجمع الباحث بين رؤية المتخصصين و غير المتخصــين في مدي اكتساب الطلاب لهذه المهار ات . • الوسائل المستخدمة في الملاحظة :

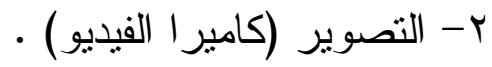
ا - التسجيل الدقيق 


\section{ثبات وصدق بطاقة الملاحظة :}

- اختبار الصدق : عرض الباحث الصورة المبدئية للبطاقة علـى (T) مسـن المحكمين من أعضاء هيئة التدريس، و أبدي المحكمون رأيهم بأن البطاقـــة

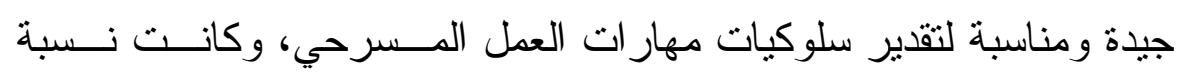

$$
\text { الاتفاق على البنود (99 و . •). }
$$

- ثبات بطاقة الملاحظة :- تم حساب ثبات بطاقة ملاحظة سلوكيات العمـلـ

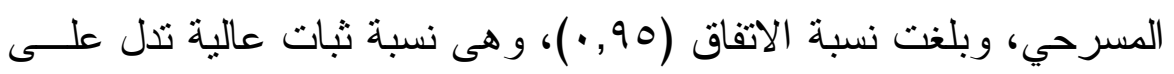

$$
\text { ז ـ النصوص البطاقة . }
$$

استعان الباحث بأربع نصوص مسرحية ذات الفصل الواحد، وقد جاء اختبار

$$
\text { هذه النصوص وفقا للآتي : - باريع }
$$

أ- احتياجات الطلاب ورغبــاتهم وميـــولهم وقــدر اتهم ومسـشاركتهم فـي

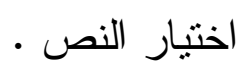

ب- مناسبة هذه النصوص المسرحية للمكــان الــذي تجــري فيــه هــذه

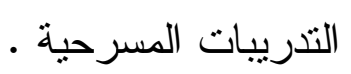

ج- مر اعاة الوقت و المدة الزمنية للتدريبات المسرحية (أي الخطة الجدوليــة

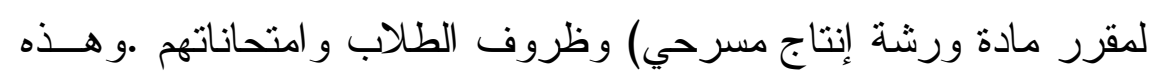
النصوص موزعة بالجدول التالي : 
فعالية التلريبات المسرحية في إكساب طلاب الإعلام التربوي مهارات العمل المسرحي ــ

جدول (0)

يوضح توزيع العينة الموضوعية

\begin{tabular}{|c|c|c|}
\hline المؤلف أو المعد & النص النص & الكلية \\
\hline عز الدين إسماعيل & مشاهدة تحت السلاح & \multirow{2}{*}{ التربية النوعية المنصورة } \\
\hline من إعداد الباحث & أزمة شرف & \\
\hline الطالب + الباحث & صياح الديوك وموت الملوك & \multirow{2}{*}{ التربية النوعية ميت غمر } \\
\hline سامي حمودة & نوبـة شجاعة & \\
\hline سامي حمودة & نوبة شجاعة & التربية النوعية منية النصر \\
\hline
\end{tabular}

هعالجة النصوص المسرحية :

مسرحية مشاهدة تحت السلاح : الفكرة الرئيسية "مسرح القتل المتعدد "

يعرض هذا النص التزر اجيدي و الذي تدور أحداثه في منزل أسرة فلـسطينية

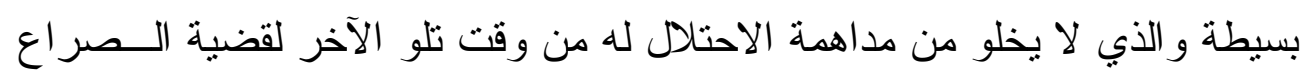
الإسر ائيلي الفلسطيني و العمليات الفدائية التي يقوم بها الفدائيون و الموصوفة من قبل

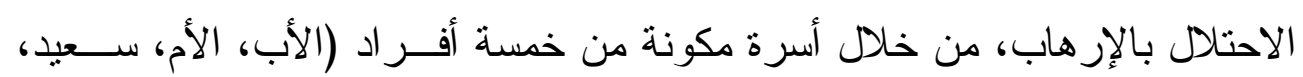

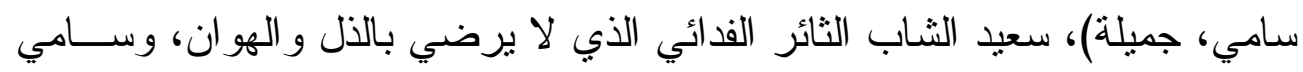

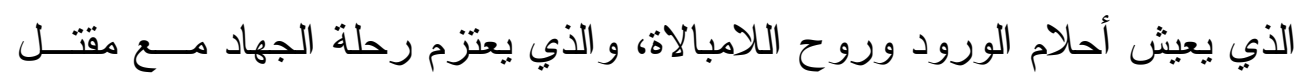

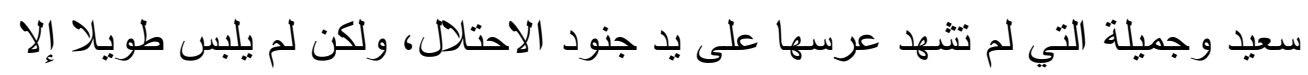

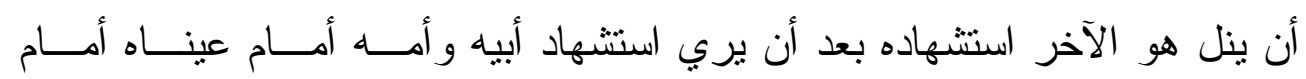

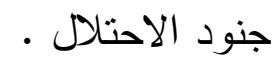

مسرحية أزمة شرف : الفكرة الرئيسية من المسئول ؟

يتعرض هذا النص المسرحي الكوميدي لنوع من الكوميديا الاجتماعية والذي تدور أحداثه في عيادة طبية نفسية، مجموعة من الضغوط و المشكلات الحياتية التي 
مجلة بحوث التربية النوعية - العدد السابع - يناير r ..r بـ

تجعل الناس في دنياهم سكارى وما هم بسكارى، نعم لم نكن أزمة شرف فحسب،

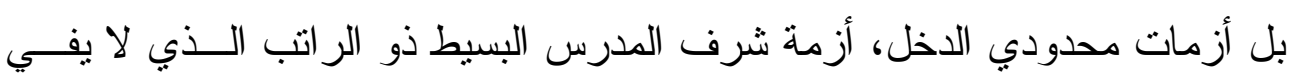

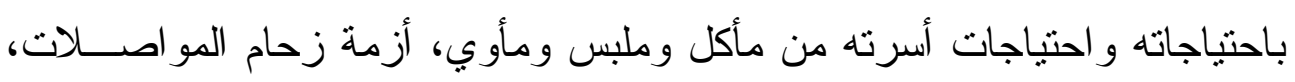

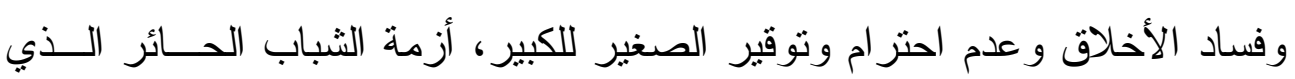
يبحث عن مكان للزو اج وما هو ببالغة، أزمة الروتين الحكومي في إنجاز مــصالح

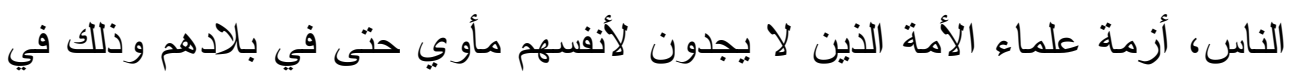

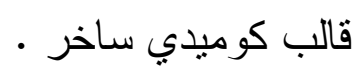

\section{مسرحية نوبة شجاعة : الفكرة الرئيسية "العلم صانع الثجاعة"}

الفقر، الجهل، المرض، منلث الموت الذي يهم بالناس في غيابـات الجـبـ

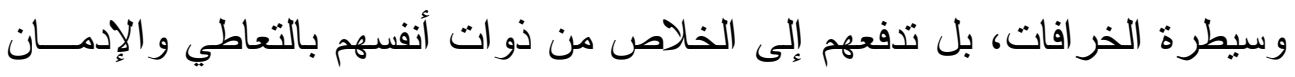

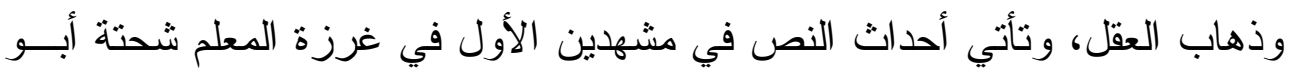

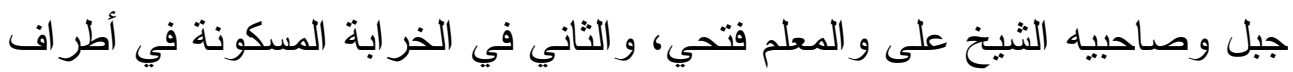

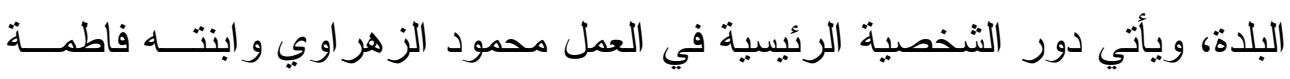

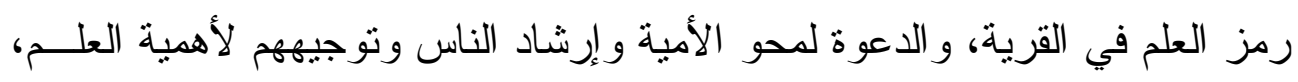

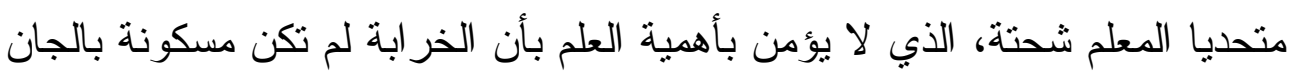

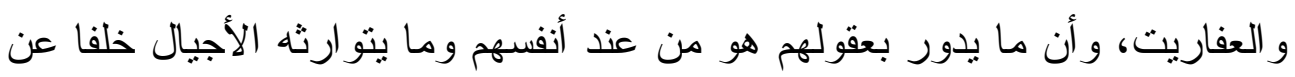
سلف مبينا أهمية العلم، فالعلم هو الذي جعل محمود الزهر اوي يؤمن بــأن الجــان مخلوقات منل البشر ولكنها، لا تسنطيع أن تؤذي أحد إلا بأذن الله، وذلك من خلايل التجربة العملية أمام أهل بلدته ـ 
فعالية التدريبات المسرحية في إكساب طلاب الإعلام التربوي مهارات العقل المسرحي ــ مسرحية صياح الديوك وموت الملوك : الفكرة الرئيسية "العدل، الأمن، السلام ليس له

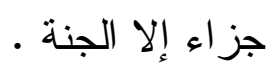

تدور أحداث النص في قصر الملك غسان حاكم ظالم يحب المال وجنس حو المال كمان، خالف عهد النبؤة ولم يحكم بين الناس بالعدل، فيلقي حتفه في منطقـــة و ادي

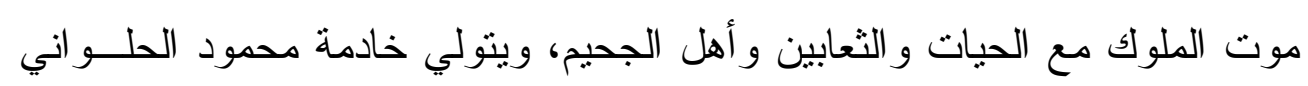

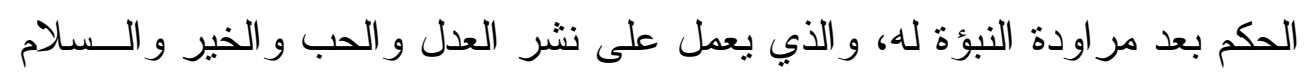

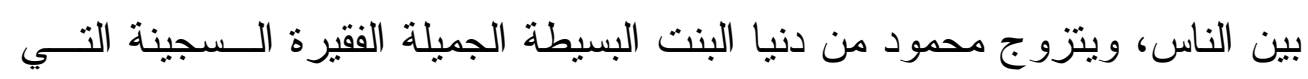
فقدت خطيبها على يد الملك غسان، وينجب منها سعيد، ويمر العام، ويسمع محمود

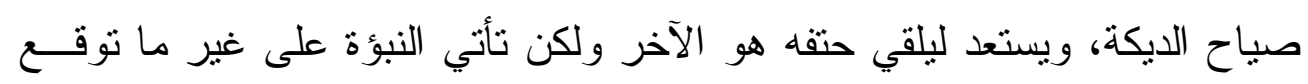

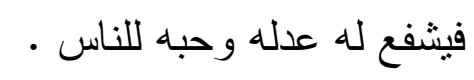

\section{خطوات تنفيذ العروض المسرحية :}

1- أختار الباحث مجموعة من النصوص المسرحية لكتاب مختلفين .

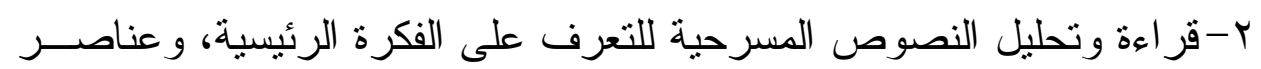

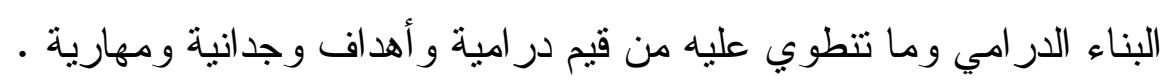

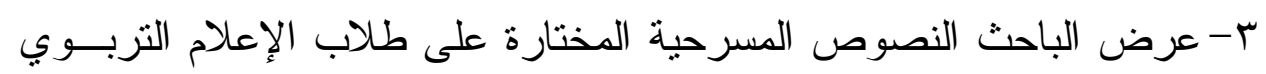

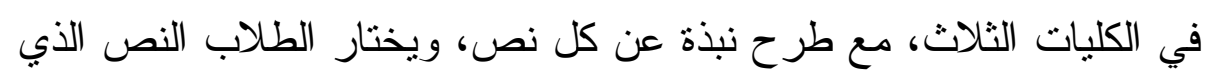

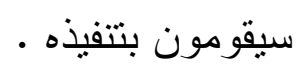

ع-تقسيم الطلاب إلى فرق عمل وكل فريق عمل مكون من سكثنين وكل فريق

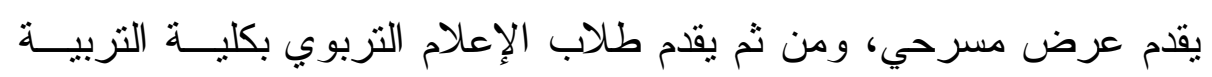

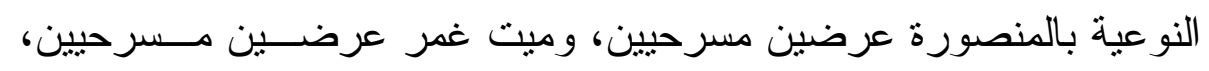

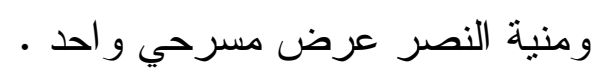
0-تقيم الطلاب داخل فريق العمل إلى مجموعات :(تمثيل، ديكور، ملابـس، ومس، 


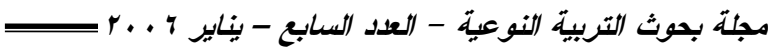

$$
\text { موسيقي، إضاءة، ماكياج و إكسسو ار ، إخر اج) • }
$$

1-توزيع النصوص المسرحية على الطلاب كل حسب فريق العمل الذي بنتمي

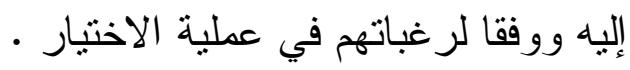

V- Vر اعة النصوص المسرحية مع الطلاب ومناقتنته فيها و الاستماع إلى آر ائهر.

1-قدم الطلاب بعض النصوص المسرحية التي من تأليفهم، ومناقثتهم فيهــا -

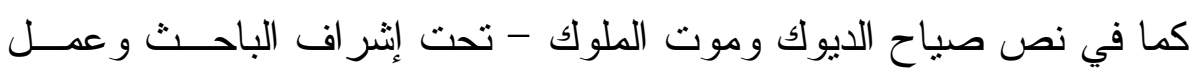

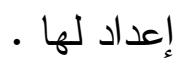

9-توزيع الأدوار على الطلاب (الممثلين) داخل كل فريق عمل .

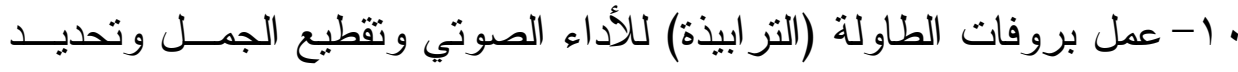

أماكن الوقفات و السكتات لمجموعات التمثيل في حضور كل فريق العمل .

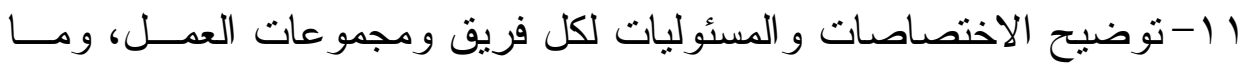
ستكون عليه خطة عمل كل فريق وكل مجموعة داخل هذا الفريـق بمعنـي

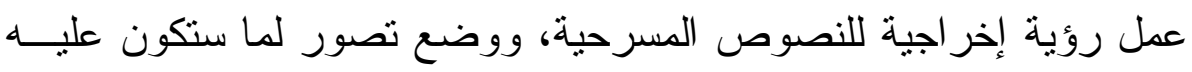

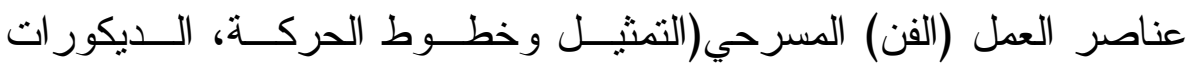
و المناظر المسرحية، الملابس، الموسيقي والمؤثز ات الــصوتية، الإضــــاءة و المؤثرات الضوئية، الماكياج و الإكسسوار ات) و إثر الك الطلاب في ذلــلك، ويمكن تتاول ذلك كما يلي :

\section{الديكورات والمناظر المسرحية :}

تتوعت المناظر و الديكور ات المسرحية ما بــين مرســوم علــى القـــاش و المصنو ع من الخشب 
فعالية التلريبات المسرحية في إكساب طلاب الإعلام التربوي مهارات الععل المسرحي ــ

\section{مسرحية مشاهدة تحت السلاح:}

\section{:قع المسرحية في مشهدين :}

المشهـ الأول : بانور اما خلفية سمر اء اللون مكتوب عليها القــس عربيــة

باللون الأحمر وكأنها تتقط دما.

و الثاني لمنزل فلسطيني بسيط تدور أحداثه في صالة المنزل ثلاث برتكابلات

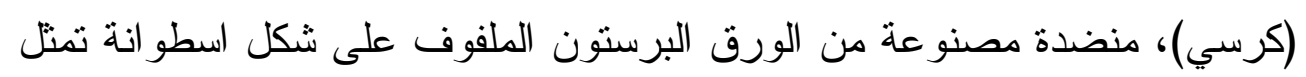

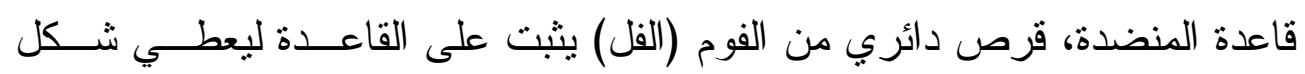
المنضدة، مفرش، شاسيه من إطار خشبي مع ورق النصبييان ليفصل بين الــصالة وحجرة داخلية، قطعة سجادة حمر اء تحت المنضدة .

\section{مسرحية أزمة شرف : م}

عيادة نفسية، مكتب، كرسي، برتكابل، سرير، شاسيه خشبي ارتفاع rم ×

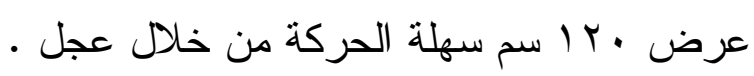

\section{مسرحية صياح الديوك وموت الملوك:}

قاعة عرش ملكية : تم تصنيعها من الخشب، برتكابل برتفــع عـن خـشبة

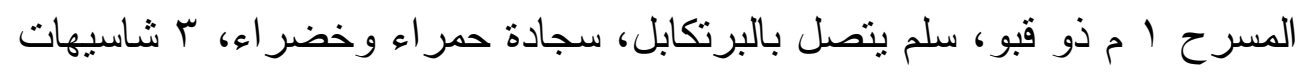
مصنوعة من الخشب الابلكاش سهلة الحركة من خلال عجل، توضع على جو انب

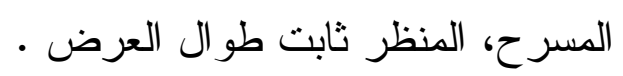

\section{مسرحية نوبة شجاعة :}

المنظر غرزة في أطر اف البلدة، تم تصنيعها من الخشب، (ع) برتكــابلات، برتكابل على شكل منضدة بسيطة، تكة (بوفيه) يوضع عليها مستلزمات الغــرزة، 


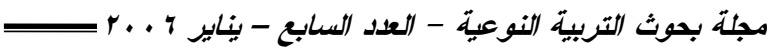

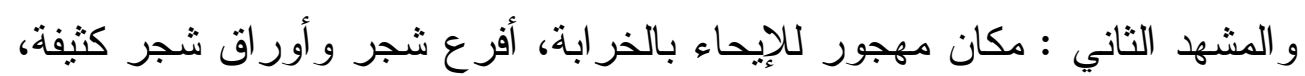
نخلة، سور مهدوم تم تتفيذه من أقفاص الجريد المغطي بالخيش الأسود . الملابس : تم الاستعانة بها من قبل الطلاب، وتم تحديد ملابس كل شخـصـية

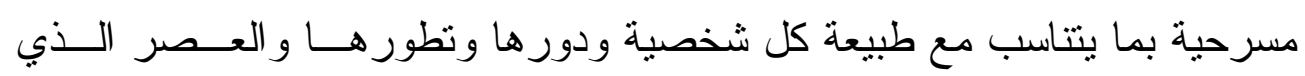

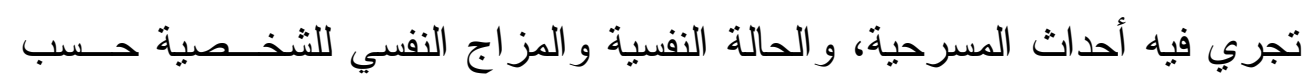
متطلبات النص و العرض المسرحي . ملهرئ

\section{الموسيقى والمؤثرات الصوتية}

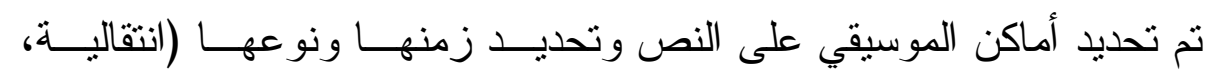

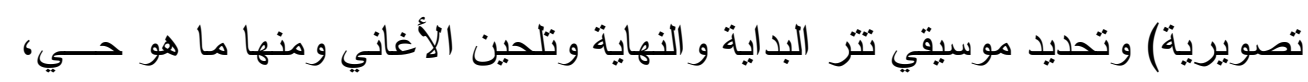

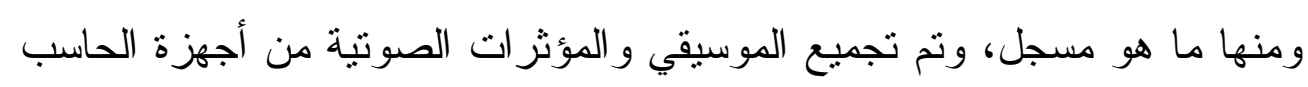

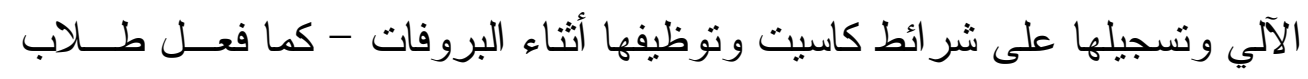

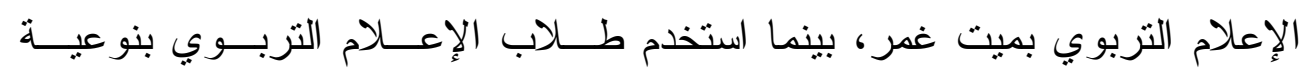
المنصورة جهاز الكمبيوتز مباترة في عمل الموسيقي، في حين أن طلاب الإعلام التزبوي بنوعية منية النصر استعانو ا بزملائهم في قسم الموسيقي في عمل الألحان

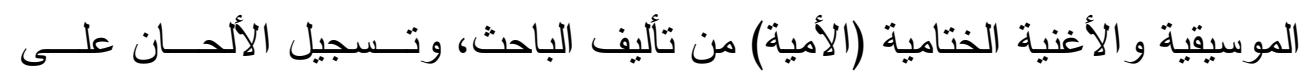

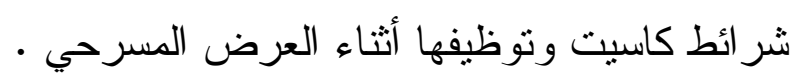

\section{الإضاءة المسرحية والمؤثرات الضوئية :}

تعاون الطلاب في الكليات الثناث كل في كليته في تجهيز مكــان العـرض

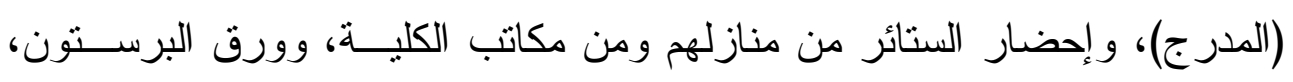

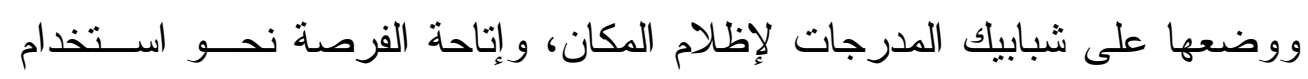

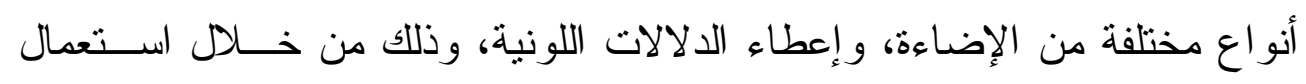

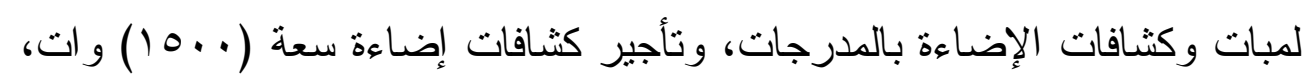


فعالية التدريبات المسرحية في إكساب طلاب الإعلام التريوي مهارات الععل المسرحي ــ

ولمبات الإضاءة ( . . . و وات، ووضعها في علب السمن الصناعي الفارغة المثقوبة من الخلف و المتصلة بسلك كهربي وفيشة ومشترك، و واســتخدم الـسلفان الأحمـر و الأزرق و الأصفر وورق الثفاف، و أكياس البلاستيك الملونة الثفافة على بعد من ومنئن اللمبات لإعطاء الدلالات اللونية والدر امية للمشاهد و إمكان تصوير العرض فيديو،

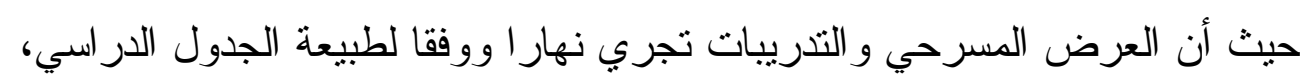
و عمل مؤثرات ضوئية من خلال إناء به نار ووضع به بخور ليعطـي الإحسـساس

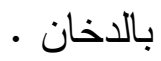

\section{الماكياج والإكسسوارات المسرحية :}

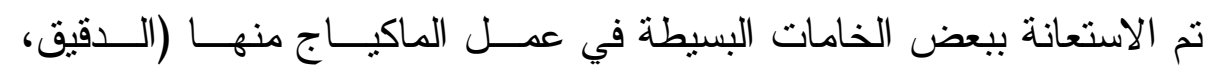

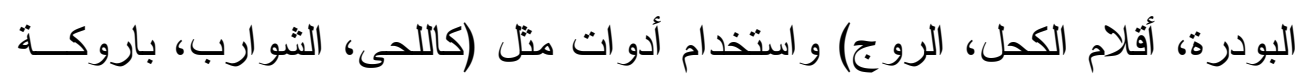

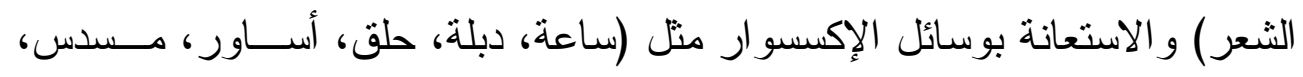
بندقية مصنوعة من الفل و الخشب، السيوف، الحراب، تليفون، جهاز ضغط، نتيجة

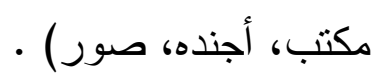

\section{تدريبات الصركة :}

تم تقسيم المسرحيات إلى مشاهد وتم تدريب الطلاب على كل مشهر على حده وبعد الانتهاء من حفظ الحوار و الحركة (لمجموعة التمنيل) في تو اجد المجموعات الأخرى، يتم الانتقال إلى المشهد الثاني حتى يتم الإنهاء منه، وقبل البدء في المشهـ

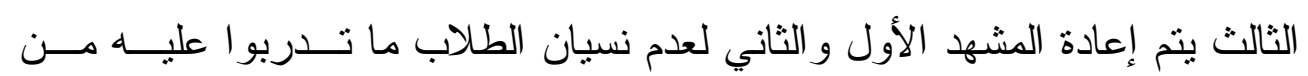

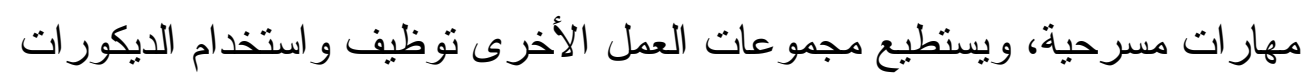

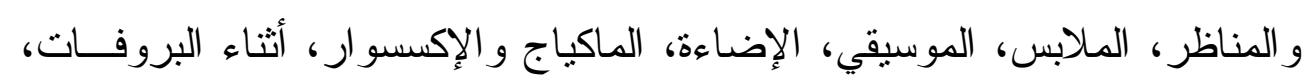

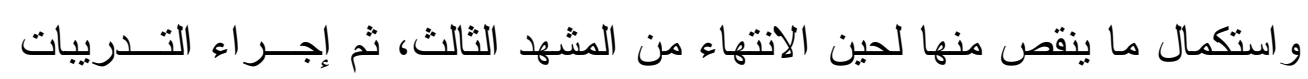

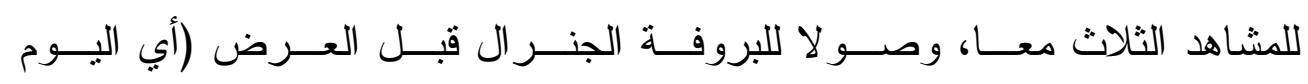


استغرقت فترة التدريبات المسرحية لفرق العمل في الكليات الــثلاث ثلاثـــة

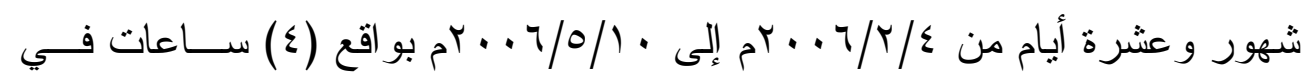

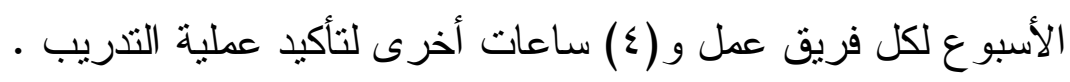

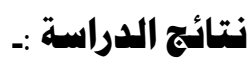

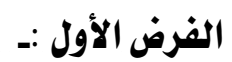

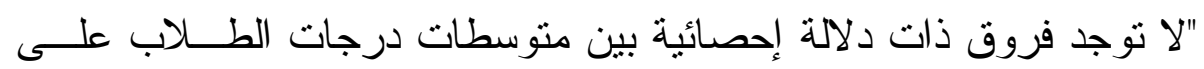

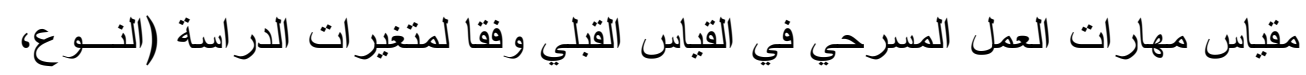
المؤهل قبل الجامعي، المجموعة التي يشارك فيها الطالب، مكان الكلية)".

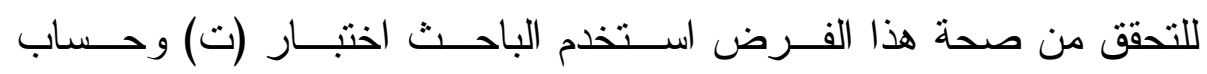
المتوسطات الحسابية و الانحر افات المعيارية ودرجة الحرية ومستويات الدلالة لكل متغير من هذه المتغير ات على النحو التالي : 1- النوع : ويمكن تتاول نتائجه في الجدول النالي : 
فعالية التلريبات المسرحية في إكساب طلاب الإعلام التربوي مهارات الععل المسرحي سل

جدول (7)

اختبار (ت) لالالة الفروق بين متوسطات درجات الطلاب وفقا لمتغير النوع في القياس القبلي

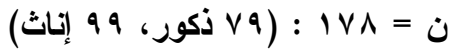

\begin{tabular}{|c|c|c|c|c|c|c|c|c|}
\hline \multirow{3}{*}{ مستوى الالالة } & \multirow{3}{*}{ |درجة الحرية } & \multirow{3}{*}{ قيمة ت } & \multicolumn{4}{|c|}{ النوع } & \multirow{3}{*}{ المهارة } & \multirow{3}{*}{ b } \\
\hline & & & \multicolumn{2}{|c|}{ إناث } & \multicolumn{2}{|c|}{ ذكور } & & \\
\hline & & & $\varepsilon$ & 5 & $\varepsilon$ & ${ }^{*}$ & & \\
\hline$\cdot, 9 \wedge \vee$ & 187 & $\cdot, \cdot I V$ & $v, 1$ & $r, r r$ & $v, 7$ & $r, r \leq$ & التمثيل & 1 \\
\hline •, rqu & 187 & $1, .07$ & $r, \tau$ & $1 \cdot, \wedge 9$ & $r, 0$ & $11, \leqslant 4$ & الديكور & r \\
\hline$\cdot$, ro. & 187 & 1,100 & $r, \wedge$ & $\wedge, \wedge \wedge$ & $r, 1$ & $q, r q$ & الملابس & $r$ \\
\hline$\cdot, r v r$ & 187 & $\cdot, \wedge 97$ & $\varepsilon, v$ & $1 \leq, \leq \leqslant$ & $\leqslant, 9$ & $10, .9$ & الموسيقى & $\varepsilon$ \\
\hline$\cdot, \cdot \vee \vee$ & $1 \leq 1$ & $1, \vee \vee$. & $r, v$ & $9, ० \mathrm{~V}$ & $r, 0$ & $1 \cdot, \leqslant r$ & الإضاءة & ० \\
\hline ه ؛ •, • دال & VYY & $r, \cdot r r-$ & $r, r$ & 7,74 & r. - & 0,99 & |الماكياج و الإكسوار| & 7 \\
\hline$\cdot, \leqslant \leqslant 9$ & 187 & $\cdot, v \circ q$ & 0,1 & rq, $1 r$ & $\checkmark, r$ & $r q, \wedge 1$ & التعاون & $v$ \\
\hline$\cdot, \leqslant \uparrow \wedge$ & 187 & $\cdot, \vee \vee Q 0$ & $r 1,1$ & $11 \cdot, \times 9$ & YY, \& & $11 r, r q$ & الإخر اج & $\wedge$ \\
\hline
\end{tabular}

من الجدول السابق يتضح عدم وجود فـروق ذات دلالـــة إحــصائية بـين متوسطات درجات الطلاب الذكور و الإناث على مقياس مهار ات العمل المـسرحي في القياس القبلي وفقا لمتغير النوع، فهي غير دالة إحصائياً ما عدا البعد الـسـادس مهارة (الماكياج و الإكسسوار) حيثث وجدت فروق دالة إحصائياً لصالح الإنـاث . حيث بلغت قيمة المتوسط الحسابي لهن (7 7, 7) مقابل منوسط حسابي، بلغت قيمته

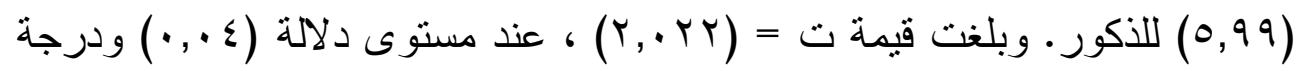
حرية (IVT) و هذا شيء طبيعي فمهارة الماكياج و الإكسسو ار مهــارة يهــتم بهــا الإناث عن الذكور، وهم أكثر معرفة وخبرة بها دون در اسة .

* الرمز (م) يلل على المتوسط الحسابي، (ع) يلل على الاحر اف المعياري . 


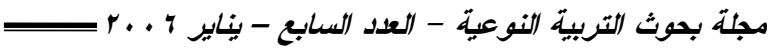

r- المؤ هل قبل الجامعي * : ويمكن نتاول نتائجه في الجدول التالي :-

(V) جدول (1)

اختبار (ت) لدلالة الفروق بين متوسطات درجات الطلاب وفقا لمتغير المؤهل قبل الجامعي

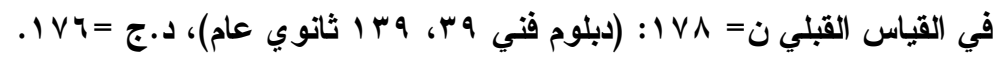

\begin{tabular}{|c|c|c|c|c|c|c|c|}
\hline \multirow{3}{*}{ |مستوى الدلاية| } & \multirow{3}{*}{ قيمة ت } & \multicolumn{4}{|c|}{ النوع } & \multirow{3}{*}{ المهارة } & \multirow{3}{*}{ b } \\
\hline & & \multicolumn{2}{|c|}{ إناث } & \multicolumn{2}{|c|}{ ذكور } & & \\
\hline & & $\varepsilon$ & م & $\varepsilon$ & * & & \\
\hline$\cdot, 9 \wedge$. & .,. ro & V.- & rI, r r & $\wedge, \varepsilon$ & rו & التمثيل & 1 \\
\hline$\cdot, v \leq 1$ & ו וr, & $r, \tau$ & $11, .9$ & $r, \varepsilon$ & $|1, r|$ & الديكور & r \\
\hline יצד, & $\cdot, 1 \leq V$ & $r, \cdot$ & $9, .9$ & $r, q$ & 9,11 & الملابس & $r$ \\
\hline., .70 & $1, \wedge \bullet 1$ & $\varepsilon, 7$ & $1 \leq, r \wedge$ & $0, r$ & $10,9 v$ & الموسيقى & $\varepsilon$ \\
\hline$\cdot, 1 \leq r$ & $1, \leqslant v 1$ & $r, \cdot$ & $9, \vee \checkmark$ & $r, \varepsilon$ & $1 ., 09$ & الإضاءة & ○ \\
\hline r & .VrA - & $r, r$ & $Y, \leqslant r$ & $r, l$ & 7,14 & الماكياج و الإكسسوار & 9 \\
\hline •, tr & $. \leq r \leq-$ & $0, \wedge$ & rq,or & $7, \varepsilon$ & $r q, \cdot \wedge$ & التعاون & v \\
\hline., 711 & $\cdot, 01$ & $r, r$ & $111,0$. & ד, & $11 r, 01$ & الإخراج & $\wedge$ \\
\hline
\end{tabular}

من الجدول السابق يتضح عدم وجود فــروق ذات دلالـــة إحــصائية بــين

متوسطات درجات الطلاب في القياس القبلي وفقا لمتغير المؤهل قبــل الجــامعي، حيث تقاربت المتوسطات الحسابية لهم، و هذا يرجع إلى أن الطلاب ســو اء كـانو ا حاصلين على دبلوم فني أو جامعة عمالبة أو معهد فني صناعي أو ثانويـــة عامـــة و التحاقهم بقسم الإعلام التربوي بكلية التربية النوعية فيما بعد ليس لله تأثنر علـى عـى مهار ات العمل المسرحي في القياس القبلي، فالطلاب نكاد تكون معلوماتهم و احــدة عن هذه المهارة و أنهم ليس لديهم سابق خبرة .

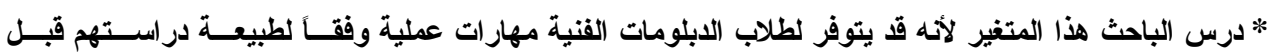

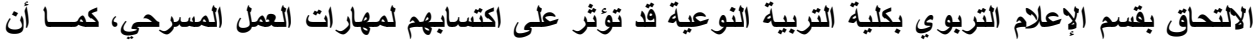

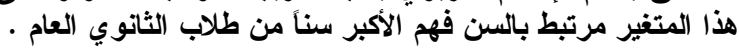

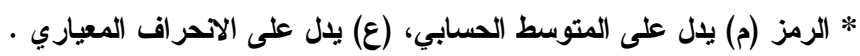


فعالية التلدريات المسرحية في إكساب طلاب الإعلام التربوي مهارات العمل المسرحي ــ

r- المجموعة التي يشارك فيه الطالب : للتحقق من عدم وجود فـروق ذات

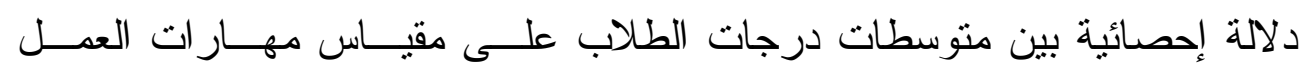

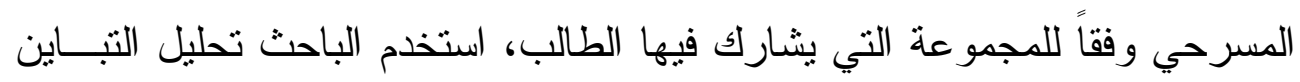

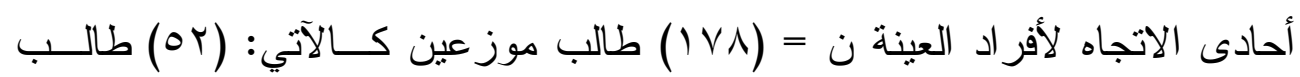

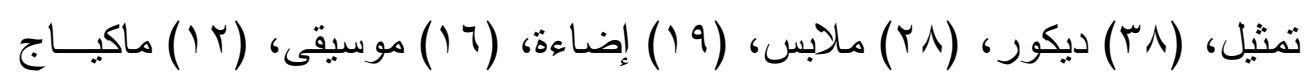

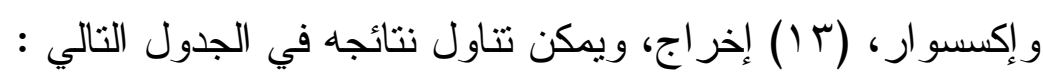


جدول (^)

تحليل التباين أحادى الاججاه لالالة الفروق في المتوسطات وفقاً للمجموعة التي يشارك فيها الطالب

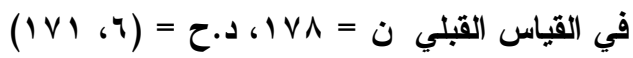

\begin{tabular}{|c|c|c|c|c|c|c|c|c|c|c|c|c|c|c|c|c|c|c|}
\hline \multirow{2}{*}{ مستوى الالالة } & \multirow[t]{2}{*}{ قيمة ف } & \multicolumn{2}{|c|}{ الارجة الكلية | } & \multicolumn{2}{|c|}{ الإخراج } & \multicolumn{2}{|c|}{ والإكسسوار } & \multicolumn{2}{|c|}{ الموسيقى } & \multicolumn{2}{|c|}{ الإضاءة } & \multicolumn{2}{|c|}{ الملابس } & \multicolumn{2}{|c|}{ الايكور } & \multicolumn{2}{|c|}{ التمثيل } & \multirow[t]{2}{*}{ المهارة } \\
\hline & & $\varepsilon$ & p & $\varepsilon$ & م & $\varepsilon$ & p & $\varepsilon$ & م & $\varepsilon$ & p & $\varepsilon$ & م & $\varepsilon$ & p & $\varepsilon$ & م & \\
\hline | . ., , .دال & $r, \cdot \Lambda_{1}$ & $v, r$ & $r, r r$ & $v, \cdot$ & גוr,r & $0, \cdot$ & $r q, Y r$ & $\wedge, q$ & $r \varepsilon,$. & $\Lambda, r$ & $r ., T r$ & $\varepsilon, 9$ & $r \cdot, r r$ & $\bullet, \wedge$ & rV,qr & $\wedge, 1$ & . & التمثيل \\
\hline$\cdot, \leqslant \uparrow \cdot$ & $1, .11$ & $r, \tau$ & $11,1 \leq$ & $r, q$ & $11, r 1$ & $r, \Lambda$ & $1 r, \cdot A$ & $\varepsilon, 0$ & Ir,O. & $r, \tau$ & 11,71 & $r, v$ & $1 \cdot, 0 \leqslant$ & $r, r$ & $11, r \leq$ & $r, r$ & $1 ., 0 r$ & الايكور \\
\hline ., & 1,001 & $r, \cdot$ & 9,11 & $r, 1$ & Q,YT & $r, r$ & $\Lambda, q Y$ & $\varepsilon$, & $1 ., 1 \pi$ & $r, r$ & $q, r v$ & $r, v$ & $9, \leqslant 4$ & $r, v$ & $V, q Y$ & $r, \cdot$ & $q, r \wedge$ & الملابس \\
\hline | & $r, . \leq 4$ & $\varepsilon, \wedge$ & $1 \leqslant, V \mu$ & $0, v$ & $10, Y \mu$ & $\varepsilon, 0$ & $1 \leqslant, 7 V$ & $v, \cdot$ & $1 \Lambda, 1 T$ & $\varepsilon, r$ & $10, \ldots$ & $r, r$ & $1 \leqslant, \mu q$ & $\varepsilon, \varepsilon$ & Ir, rr & $\varepsilon, 0$ & $1 \leqslant, V 1$ & الموسيقى \\
\hline .,०^4 & $\cdot, \vee \wedge$. & $r, 1$ & १,१ & $r, v$ & $1,0 \leq$ & $1, v$ & 9,94 & $\varepsilon, r$ & $1 \cdot, v_{0}$ & $r, \varepsilon$ & 1., & r. - & $9, \leqslant 4$ & $r, r$ & Q,rr & $r, r$ & $1 \cdot, \cdot r$ & الإضاءة \\
\hline | •. ., .دال & r, $10 r$ & $r, r$ & ४ & r. r & ४, १५ & $r, 0$ & $\vee, \wedge r$ & r. 1 & 7,15 & $r, v$ & $\checkmark, \vee 9$ & 1.1 & $\checkmark, \vee 1$ & $r, 1$ & זוז & r. 1 & 4,14 & الماكياج \\
\hline גזו, & $\cdot, \times 10$ & 0,9 & $r q, \leqslant r$ & $\checkmark, \varepsilon$ & $\curlyvee \wedge, \wedge \bullet$ & $\checkmark, \cdot$ & rq, ro & $7, \varepsilon$ & $r_{1, \mu l}$ & 7,0 & $r v, O r$ & $0, \varepsilon$ & ץ৭,४^ & $0, \varepsilon$ & $r q, \ldots$ & 7,1 & rq,qr & التعاون \\
\hline צ & 1,7. & $r u, v$ & $111,9 \leq$ & rq, & $110, \leqslant 4$ & IV, $\varepsilon$ & $\| r, \ldots$ & $r q, 0$ & IrY,q & Tr, & rז, 111 & $1 \leqslant, 9$ & $11 \cdot, 0 \leqslant$ & $i v, r$ & 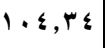 & $r r, r$ & $11 \leqslant, 1$. & الإخراج \\
\hline
\end{tabular}


فعالية التلديبات المسرحية في إكساب طلاب الإعلام التربوي مهارات العدل المسرحي

من نتائج الجدول السابق يتضح عدم وجود فروق ذات دلاله إحصائية بـين

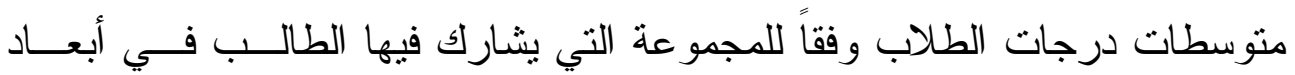

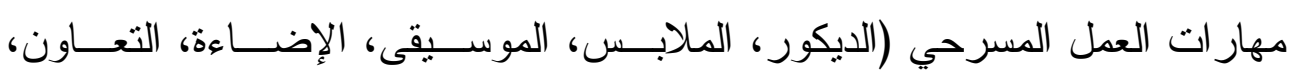

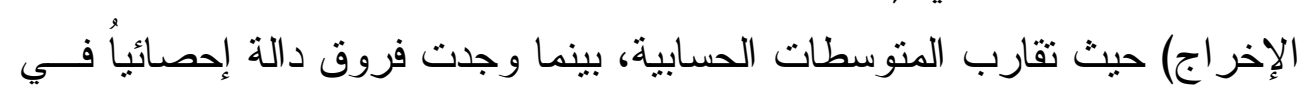

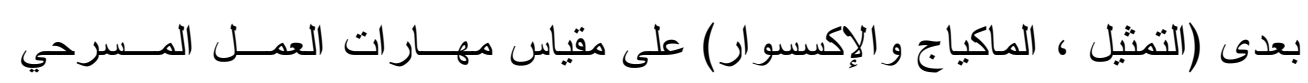

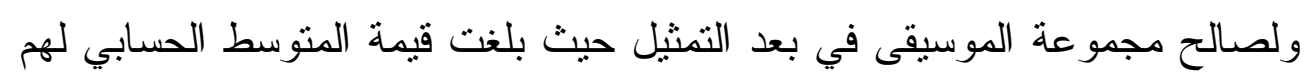

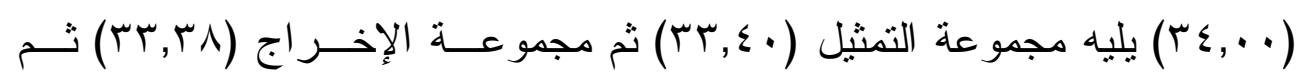

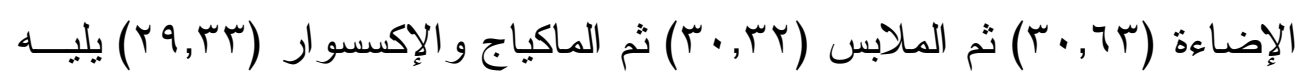

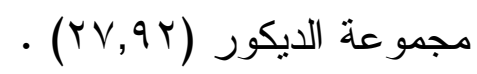
كما وجدت فروق داله إحصائياً بين مجموعات الطلاب في بعــد الماكيــاج

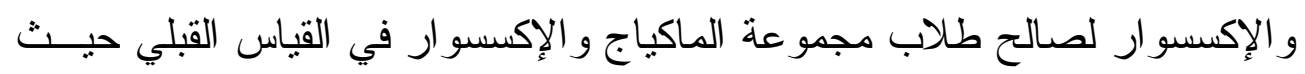

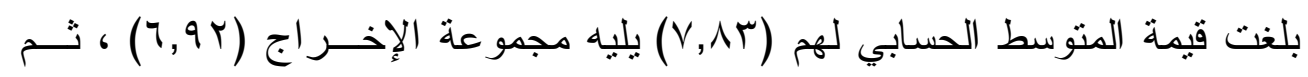

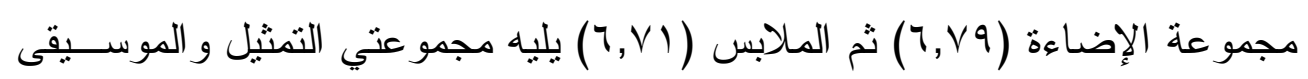

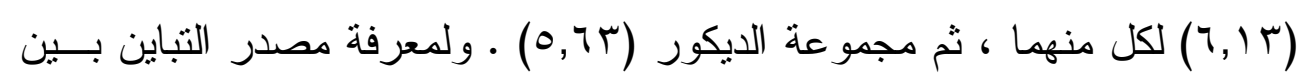

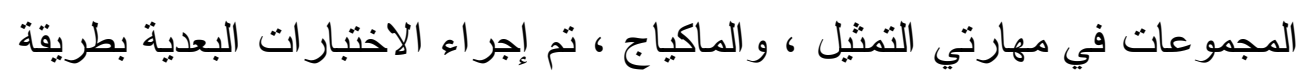
أقل فرق معنوي (LSD) وتظهر نتيجتها في الجدول التالي : 


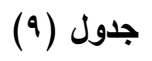

مصدر التباين بين المجموعات في مهارتي التمثيل والماكياج في القياس القبلي وفقا لمتغير المجموعة التي يشارك فيها الطالب

\begin{tabular}{|c|c|c|c|c|c|c|c|c|c|c|c|c|c|}
\hline \multicolumn{12}{|c|}{ المجموعة (ل ) } & \multirow{3}{*}{ المجموعة (1) } & \multirow{3}{*}{ المهارة } \\
\hline \multicolumn{2}{|c|}{ إخر اج } & \multicolumn{2}{|c|}{ ماكياج و إكسسوار } & \multicolumn{2}{|c|}{ موسيقى } & \multicolumn{2}{|c|}{ إضاعة } & \multicolumn{2}{|c|}{ ملابس } & \multicolumn{2}{|c|}{ ديكور } & & \\
\hline$د$ & $1-j$ & $د$ & $1-j$ & $د$ & $1-j$ & $د$ & $1-j$ & $د$ & $1-j$ & $د$ & $1-J$ & & \\
\hline •, & $\cdot, \cdot r$ & $\cdot, \cdot \vee v r$ & $\varepsilon, \cdot V$ & $\cdot, \vee \vee \curlyvee \wedge$ & $\cdot, 7 \cdot-$ & $\cdot, 1 \leq \varepsilon$ & $r, V \vee$ &., $.7 \leq$ & $r, . \Lambda$ & $\cdot, \cdots$ & $0, \leqslant \wedge$ & تمثيل & \\
\hline$\cdot, \cdot 1 \mathrm{~V}$ & $0, \leqslant 7-$ &., $0 \leq 7$ & $1, \leqslant 1-$ & $\cdot, \ldots \varepsilon$ & $7, \cdot 1-$ & $\cdot, I V r$ & Y,V I- & $\cdot, I \vee r$ & Y, \&.- & & & ديكور & \\
\hline$\cdot, 19 \mathrm{~V}$ & $r, .9-$ & $\cdot, \uparrow \wedge$ & $\cdot, 99$ &., .91 & 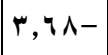 & $\cdot, \wedge \wedge \mathrm{r}$ & $\cdot, r_{1-}$ & & & & & ملابس & التمثيل \\
\hline$\cdot, r \vee q$ & $r, v ०-$ & A & $1, r$ &., 171 & $r, r v-$ & & & & & & & إضاءة & \\
\hline$\cdot, \wedge 10$ & זיד, & $\cdot, \cdot \wedge \bullet$ & $\varepsilon, T V$ & & & & & & & & & موسيقى & \\
\hline$\cdot, 10 r$ & $\leqslant, .0-$ & & & & & & & & & & & ماكياج و إكسسو ار & \\
\hline$\cdot r \leq r$ & $\cdot, \vee \vee q-$ &., .17 & $1, v \cdot-$ & $\cdot, 9 \wedge \wedge$ & $\cdot,+1$ & יזr, & $\cdot, 70-$ & $\cdot, r \circ q$ & $\cdot, \diamond \wedge-$ & $\cdot, r \vee q$ & $\cdot, 0$ & تمثيل & \\
\hline ., & $1, q_{-}$ & $\cdot, \ldots r$ & Y,Y.- & $\cdot, \leqslant \leqslant V$ & $\cdot, \leqslant 9-$ &., .09 & $1,17-$ & $\cdot,+, \leqslant V$ & $1, \cdot 1$ & & & ديكور & $-1<<4$ \\
\hline$\cdot, \vee \vee \vee$ & $\cdot, Y_{1-}$ & $\cdot, I r v$ & $1,1 Y-$ & $\cdot, r \wedge \wedge$ &., 09 & $\cdot, q \cdot v$ & $\cdot, \cdot \wedge-$ & & & & & ملابس & م \\
\hline •, А५ & $\cdot, 1 r-$ & $\cdot, 19 \leq$ & $1, \cdot \leq-$ & - & $\cdot, \leqslant 9-$ & & & & & & & إضاءة & \\
\hline צד & $\cdot, \wedge \cdot-$ & $\cdot, \cdot, \leqslant 1$ & $1, \times 1-$ & & & & & & & & & موسيقى & \\
\hline$\cdot$, Y94 &., 91 & & & & & & & & & & & ماكياج و إكسسوار & \\
\hline
\end{tabular}


فعالية التدريبات المسرحية في إكساب طلاب الإعلام التربوي مهارات العقل المسرحي ــ من الجدول السابق يتضح ما يلي : - وجدت فروق ذات دلالة إحصائية بين الطلاب مجموعة التمثيل ومجموعة

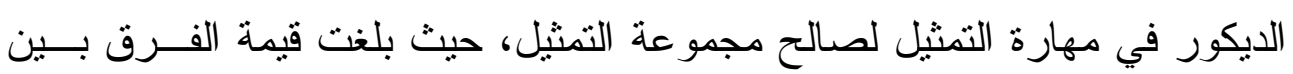

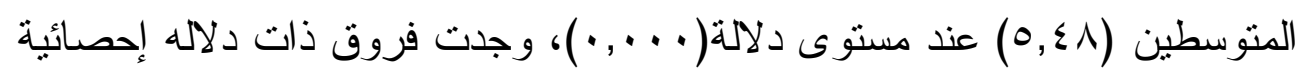

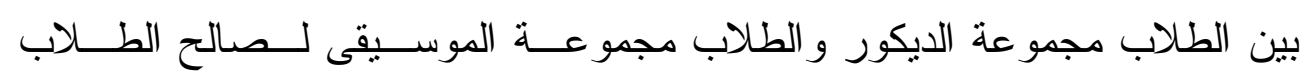

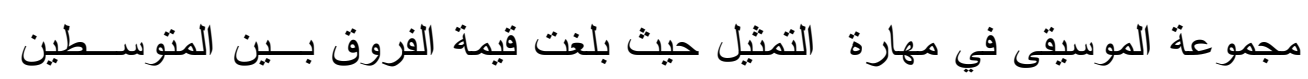

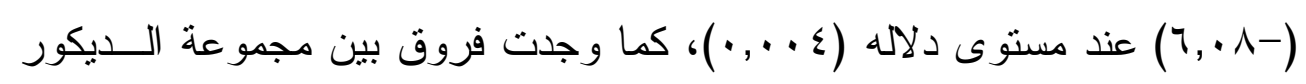

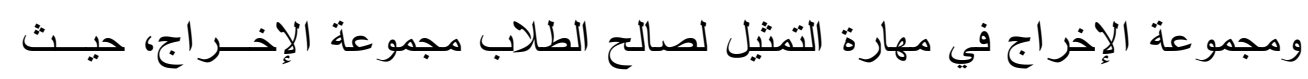
بلغت قيمة الفروق بين المتوسطين (-7 ـ,0) عند مستوى دلاله (V V ., •) . - وجدت فروق ذات دلالة إحصائية بين الطلاب مجموعة التمثيل و الطلاب

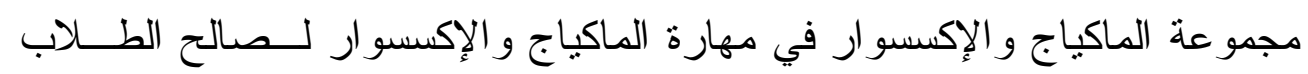

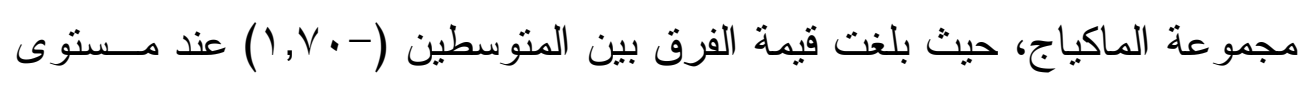

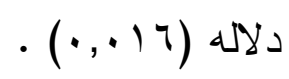

- وجدت فروق ذات دلالة إحصائية بين طلاب مجموعة الديكور وطـلاب

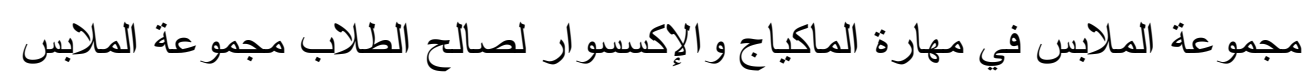

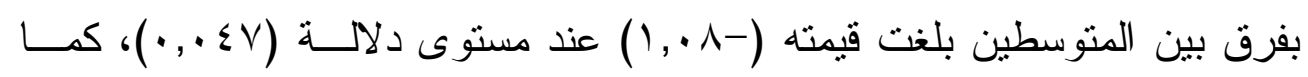

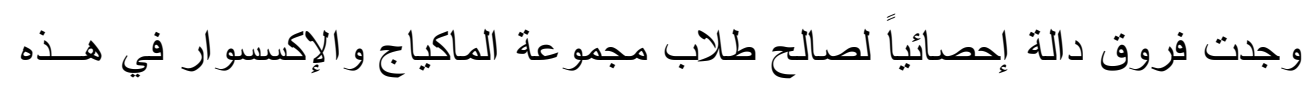

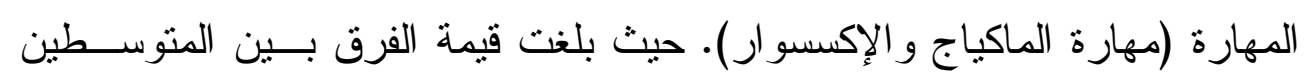

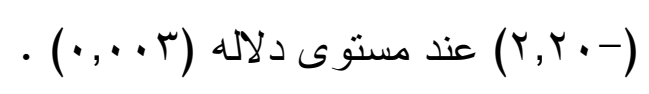

- وجدت فروق دالة إحصائياً بين الطلاب مجموعة الموســيقى و الطــلاب

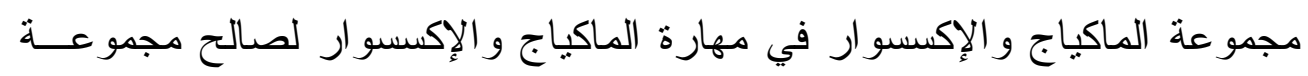

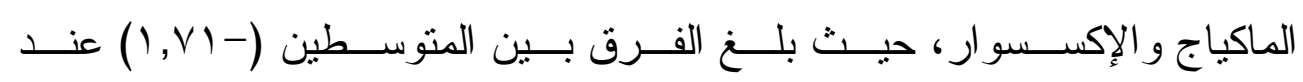




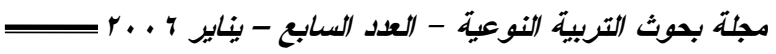

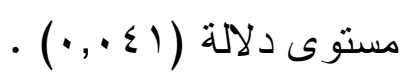

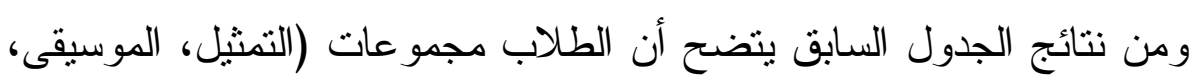

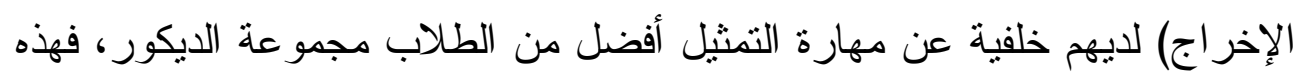

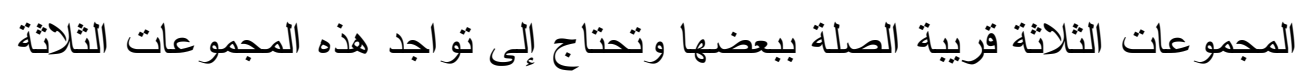

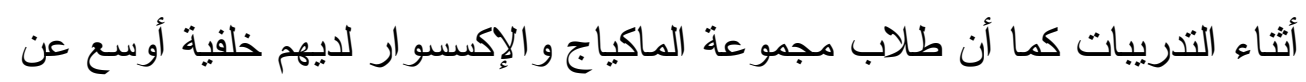

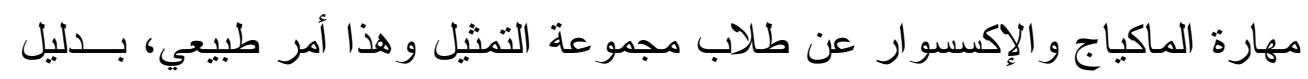

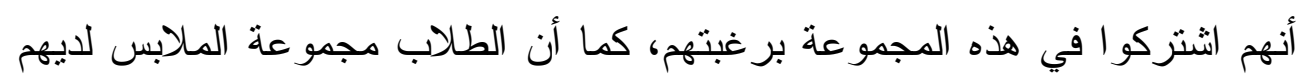

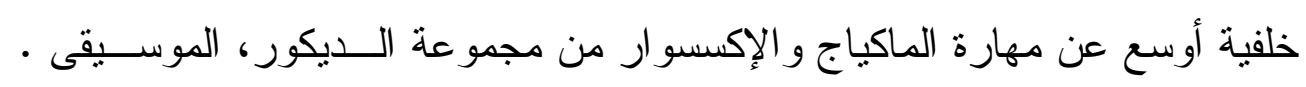

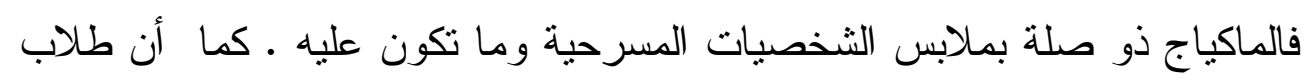

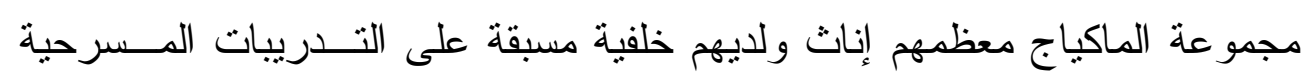
بأمور الماكياج وهذه المهارة . ماكياج

ع - الكلية : للتحقق من عدم وجود فروق دالة إحصائياً بين متوسط درجات

الطلاب على مقياس مهار ات العمل المسرحي في القياس القبلي وفقاً لمتغير الكلية :

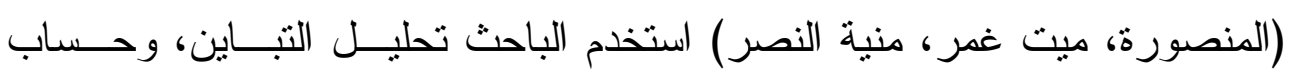

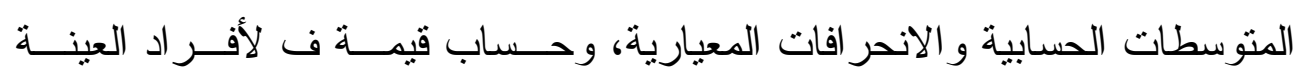

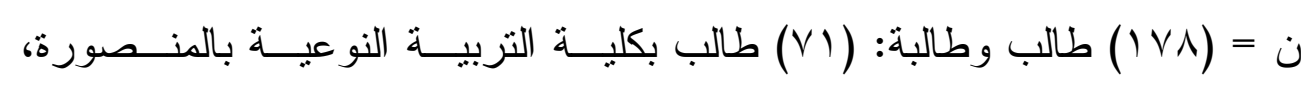

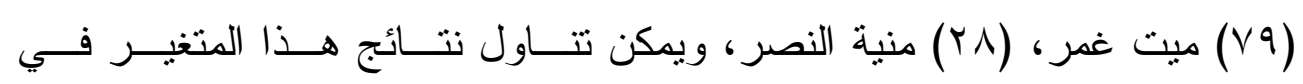

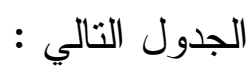


فعالية التدرييات المسرحية في إكساب طلاب الإعلام التربوي مهارات الععل المسرحي

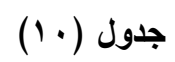

تحليل التباين أحادى الاتجاه لدلالة الفروق في متوسطات درجات الطلاب وفقا لمتغير الكلية

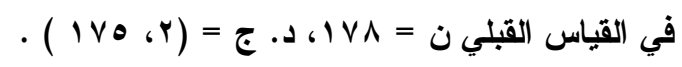

\begin{tabular}{|c|c|c|c|c|c|c|c|c|c|}
\hline \multirow{3}{*}{ الدلالة } & \multirow{3}{*}{ قيمة ف } & \multicolumn{6}{|c|}{ الكلية } & \multirow{3}{*}{ المهارة } & \multirow{3}{*}{ r } \\
\hline & & \multicolumn{2}{|c|}{ منية الصر } & \multicolumn{2}{|c|}{ ميث غمر } & \multicolumn{2}{|c|}{ المنصورة } & & \\
\hline & & $\varepsilon$ & 5 & $\varepsilon$ & 5 & $\varepsilon$ & 5 & & \\
\hline$\cdot, \ldots$ & $0,0 \leq 7$ & $V, r$ & $r \wedge, \diamond V$ & 7,7 & $r \cdot, r r$ & $v, r$ & $r r, r \wedge$ & التمثيل & 1 \\
\hline$\cdot, \ldots$ & I r,Aro & $r, \tau$ & 11,11 & $r, l$ & $৭, \wedge \leq$ & $r, 0$ & $|Y, Y|$ & الايكور & $r$ \\
\hline$\cdot, \ldots 1$ & $v, \varepsilon \cdot 1$ & $r, \varepsilon$ & $\wedge, \diamond \vee$ & $r, 0$ & $\Lambda, r q$ & $r, \cdot$ & $1 \cdot, 11$ & |لملابس | الملاب & $r$ \\
\hline$\cdot, \cdots$ & 11,079 & $r, 0$ & $1 r, 0$. & $\varepsilon, r$ & $1 \%, \Lambda$. & 0,1 & 17,70 & |الموسيقى | & $\varepsilon$ \\
\hline$\cdot$, & $q, \vee \backslash 1$ & $r, \Lambda$ & $q, r q$ & $r, 0$ & $9, \cdot 9$ & $r, 0$ & $11,1 \leq$ & | الإضاءة & 0 \\
\hline$\cdot, \cdots q$ & $\varepsilon, \wedge 1$. & $r, v$ & 7,11 & 1,9 & 0,9 . & $r, r$ & $7,9 \mathrm{~V}$ & | الماكياج | & 7 \\
\hline$\cdot, \cdots r$ & $7,7) Y$ & $\bullet, \cdot$ & $r \cdot, r \varepsilon$ & $0, r$ & YV, \A & 7,0 & $r \cdot, q$. & التعاون & v \\
\hline$\cdot, \ldots$ & $\mid \pi, \pi$ & 19,1 & $1 \cdot 7, \wedge 9$ & 18,7 & $1,0, \ldots$ & $r r, 1$ & |Y & |الإخراج & $\wedge$ \\
\hline
\end{tabular}

من نتائج الجدول السابق يتضح وجود فــروق ذات دلالـــة إحــصائية بــين متوسطات درجات الطلاب على مقياس مهار ات العمل المسرحي في القياس القبلي وفقاً لمتغير الكلية لصالح طلاب الإعلام التربوي بكلية التربية النوعية بالمنصورة

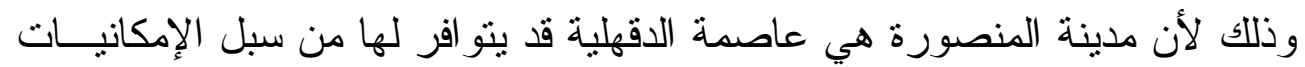

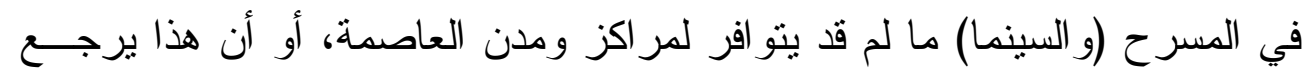
إلى وجود جو انب متعلقة بجو انب التدريس النظرية و التطبيقيــة بالكليــة النوعيــة بالمنصورة عن نوعية ميت غمر ومنية النصر • - ولمعرفة مصدر التباين استخدم الباحث الاختبار ات البعدية بطريقة (LSD) (طريقة أقل فرق معنوي) و الذي يمكن تناول نتائجه في الجدول التالي : 


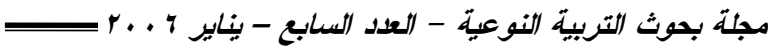

جدول (11)

مصدر التباين لالالة الفروق بين المتوسطات في القياس القبلي وفقاً لمتغير مكان الكلية .

\begin{tabular}{|c|c|c|c|c|c|c|}
\hline \multicolumn{4}{|c|}{ الكلية (ل) } & \multirow{3}{*}{ الكلية( ) } & \multirow{3}{*}{ المهارة } & \multirow{3}{*}{ p } \\
\hline \multicolumn{2}{|c|}{ منية النصر } & \multicolumn{2}{|c|}{ ميت غمر } & & & \\
\hline$د$ & $1-J$ & د & $* 1-J$ & & & \\
\hline$\cdot, \cdots r$ & $\varepsilon, V_{1}$ &.,$\cdot 1 r$ & $r, 90$ & المنصورة & (4) & 1 \\
\hline מצות • & $1, \times 4$ & - & - & ميت غمر & & \\
\hline$\cdot, \cdot \leq 4$ & 1,0 & $\cdot, \cdots$ & $r, V \vee$ & المنصورة & & \\
\hline$\cdot, \wedge 4$ & $1, r v-$ & - & - & ميت غمر & آتيولر & $r$ \\
\hline., .17 & $1,0 \leq$ &,$\ldots$ & $1, V Y$ & المنصورة & 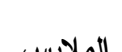 & $\mu$ \\
\hline$\cdot, \vee \vee \diamond$ & $\cdot, 1 \wedge-$ & - & - & ميت غمر & ? & \\
\hline$\cdot, \cdots$ & $\{, 10$ &,$\ldots$ & $r, \wedge 0$ & المنصورة & ت & 6 \\
\hline$\cdot, 194$ & $1, r$. & - & - & ميت غمر & & \\
\hline$\cdot, \cdots q$ & $1, \times 0$ &,$\ldots$ & $r, \cdot \Lambda$ & المنصورة & 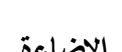 & 0 \\
\hline •, & • & - & - & ميت غمر & & \\
\hline$\cdot, \cdot \vee 0$ & $\cdot, \wedge 4$ & $\cdot, \cdot r$ & $1, \cdot v$ & المنصورة & & \\
\hline צדים & $\cdot, Y_{1-}$ & - & - & ميت غمر & 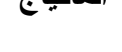 & 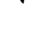 \\
\hline$\cdot, \wedge \leq$. & $\cdot, Y q$ &,$\ldots 1$ & $r, r r$ & المنصورة & |ill & $y$ \\
\hline$\cdot, \cdot r \cdot$ & r, ११- & - & - & ميت غمر & ? & \\
\hline$\cdot, \cdots 1$ & $1 \leqslant, V V$ &,$\ldots$ & 17,74 & المنصورة & & $\Lambda$ \\
\hline$\cdot, T V Y$ & $1, \wedge 9-$ & - & - & ميت غمر & & \\
\hline
\end{tabular}

من نتائج الجدول السابق يتضح وجود فروق ذات دلالة إحصائية على مقياس مهار ات العمل المسرحي في القياس القبلي ترجع لمتغير مكان الكلية (المنــصورة، ميت غمر ، منية النصر ) لصالح طلاب الإعلام التربوي بكليــة التربيـــة النوعيــة بالمنصورة وذلك في مهار ات (التمثيل، الديكور، الملابس، الموســـقي، الإضــــاءة، الماكياج، التعاون، الإخر اج) حيث أنها داله إحصائية كما هو مبين بالجدول، بينمـــا * الرمز (ل-1) يدل على الفرق بين المتوسطين، (د) مستوى الدلالة . 
فعالية التلايبات المسرحية في إكساب طلاب الإعلام التربوي مهارات الععل المسرحي ــ

لا توجد فروق داله إحصائيا بين كلية التربية النوعية بميت غمر ومنية النصر في جميع المهار ات السابقة ما عدا مهارة التعاون فكانت داله إحصائيا لــصالح كليــة التربية النوعية بمنية النصر وهذا برجع إلى أن عدد طلاب الفرقة الر ابعة بمنيــة النصر قليل (q ط طالب وطالبة) بما بسمح لهم بزيادة التفاعل و التعاون فيما بينهما . ومما سبق يتضح أن هذا الفرض تحقق جزئياً على النحو التالي:

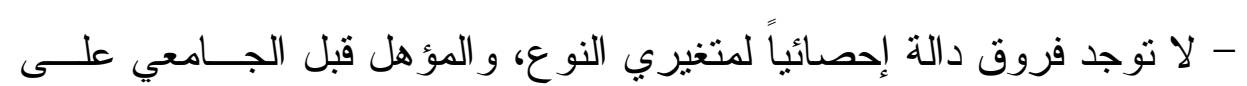
مقياس مهار ات العمل المسرحي في القياس القبلي • - وجدت فروق دالة إحصائياً في مهارتي (التمثيل، الماكيــاج و الإكسـسو ار) لصالح طلاب مجمو عات (التمثيل، الموسيقى، الإخر اج) في مهارة التمثيل . - كما وجدت فروق داله إحــصائياً لـصـالح الطــلاب مجموعــة الماكيــاج و الإكسسوار، وطلاب مجموعة المالبس في مهارة الماكيــاج و الإكسـسوار

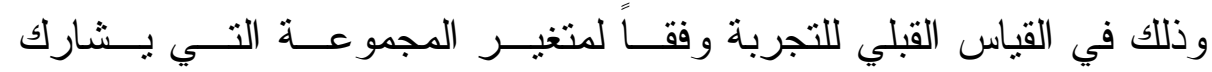
فيها الطالب آن

- وجدت فروق دالة إحصائياً على مقياس مهار ات العمل المسرحي وفقاً لمتغير

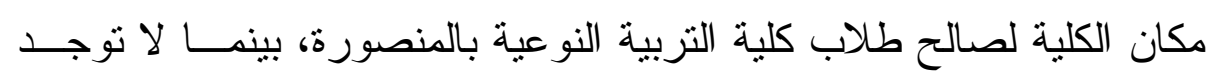
فروق دالة إحصائياً بين كلية التربية النوعية بميت غمر ومنية النصر علـى مله مقياس مهار ات العمل المسرحي في القياس القبلي ما عدا مهــارة التعــاون لصالح كلية التربية النوعية بمنية النصر ـئرية 


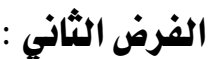

"توجد فروق ذات دلالة إحصائية بين متوسطات درجــات الطــلاب فــي مهار ات العمل المسرحي في القياس القبلي و البعدي على مقياس مهـــار ات العـــلـ المسرحي لصالح القياس البعدي" .

للتحقق من صحة هذا الفرض، الذي يبحث في معرفة دلالة الفـروق بــين متوسطات درجات الطلاب في القياس القبلي قبل إجراء التــدريبات المـسرحية القياس البعدي - بعد إجر اء التذريبات المسرحية - استخدم الباحـــ اختبــار (ت) T-Test لحساب دلالة الفروق ، وحسـساب المنوســـات الحـسـابية والانحر افــات المعيارية ويمكن تتاول النتائج في الجدول التالي :

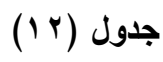

دلالة الفروق بين متوسطات درجات الطلاب في القياس القبلي والبعدي

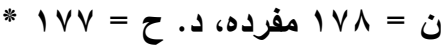

\begin{tabular}{|c|c|c|c|c|c|c|c|}
\hline \multirow{3}{*}{ الالالة } & \multirow{3}{*}{ قيمة ت } & \multicolumn{4}{|c|}{ القياس } & \multirow{3}{*}{ المهارة } & \multirow{3}{*}{ b } \\
\hline & & \multicolumn{2}{|c|}{ البعدي } & \multicolumn{2}{|c|}{ القبلي } & & \\
\hline & & $\varepsilon$ & 5 & $\varepsilon$ & 5 & & \\
\hline$\cdot, \ldots$ & $r Y, \Lambda \cdot q-$ & $\Lambda, r$ & $\varepsilon \wedge, .9$ & $v, r$ & $r, r r$ & التمثيل & 1 \\
\hline$\cdot, \ldots$ & ץ.,171- & $r, r$ & $r \cdot, \cdot r$ & $r, 7$ & $11,1 \leq$ & الايكور & r \\
\hline$\cdot, \ldots$ & IA,TVY- & $r, 1$ & $14,9$. & $r,$. & 9,11 & الملابس & $r$ \\
\hline$\cdot, \ldots$ & $r r, \leqslant 1 .-$ & $\varepsilon, 9$ & $r O, Y r$ & $\varepsilon, \wedge$ & $1 \leq, V r$ & الموسيقى & $\varepsilon$ \\
\hline$\cdot, \ldots$ & YY, MTO- & $\varepsilon, r$ & $1 \Lambda, Y^{\prime}$ & $r, 1$ & $9,9 \varepsilon$ & الإضاعة & 0 \\
\hline$\cdot, \ldots$ & $r \cdot, q \cdot \Lambda-$ & $r, \cdot$ & $1 \cdot, r r$ & r. r & $7, r 4$ & الماكياج & 7 \\
\hline$\cdot, \ldots$ & $17, r r \varepsilon-$ & $r, r$ & rq,A & 0,9 & $r q, \leqslant r$ & التعاون & v \\
\hline$\cdot, \cdots$ & $Y \wedge, 1 \Varangle V-$ & rr,. & IVY,V. & $r u, v$ & $111,9 \leq$ & الإخراج & $\wedge$ \\
\hline
\end{tabular}

من نتائج الجدول السابق يتضح وجود فروق ذات دلالة إحــصائية لــصالح

* * الرمز د. ح يعنى درجة الحرية، (د) مستوى الدلالة . 
فعالية التلدريات المسرحية في إكساب طلاب الإعلام التربوي مهارات العقل المسرحي ــ

القياس البعدي في مهار ات العمل المسرحي الثمانية، حيث ارتفعــت المتوســـات

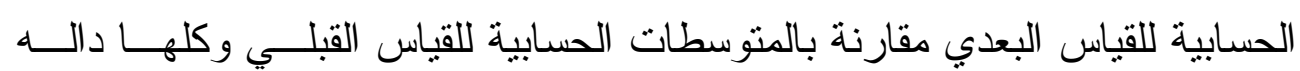

$$
\text { إحصائية عند مستوى دلالة ( . . . •) . }
$$

ووفقاً لقيمة (ت) نجد أن مهارة الإخر اج جاءت في الترتيب الأول ثم الديكور

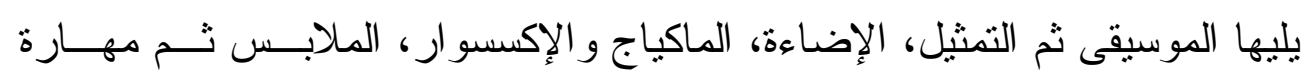

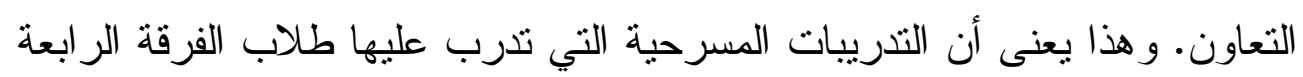
إعلام تربوي خلال در استهم لمقرر مادة ورشة الإنتاج المسرحي أكسبتهم مهار ات بلته

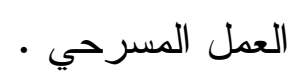
ووفقاً لما سبق يتضح تحقق الفرض الثاني كلياً .

\section{الفرض الثالث : - الث}

"توجد فروق ذات دلالة إحصائية بين متوسطات درجات الطلاب في مهار ات

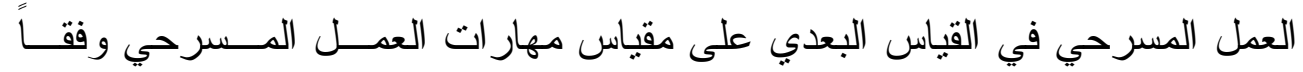

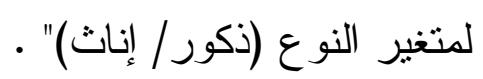

للتحقق من صحة هذا الفـرض اســتخدم الباحــث اختبــار (ت) وحسـاب

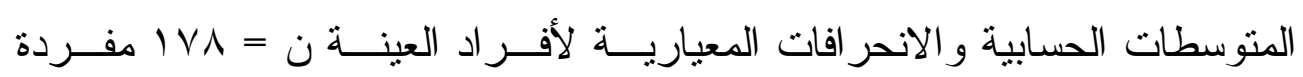

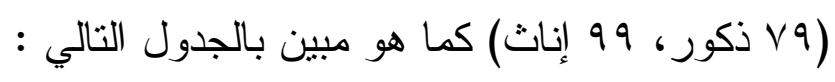




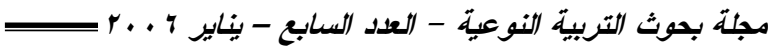

$$
\text { جدول (r) }
$$

دلالة الفروق بين متوسطات درجات الطلاب في القياس البعدي وفقاً لمتغير النوع

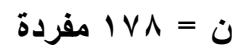

\begin{tabular}{|c|c|c|c|c|c|c|c|c|}
\hline \multirow{3}{*}{ مستوى الدلالة } & \multirow{3}{*}{ قيمة ت } & \multirow{3}{*}{ درجة الحرية } & \multicolumn{4}{|c|}{ النوع } & \multirow{3}{*}{ المهارة } & \multirow{3}{*}{ P } \\
\hline & & & \multicolumn{2}{|c|}{ إناث } & \multicolumn{2}{|c|}{ ذكور } & & \\
\hline & & & $\varepsilon$ & م & $\varepsilon$ & م & & \\
\hline$\cdot, \varepsilon r r$ & $\cdot, \wedge \cdot \leq-$ & 184 & $\Lambda, r$ & $\leqslant \Lambda, 0 \leqslant$ & $\Lambda, r$ & $\varepsilon V, \Delta r$ & التمثيل & 1 \\
\hline • . , • د دال & $\Gamma, \wedge \vee \wedge-$ & 187 & $r, q$ & $r \cdot, \wedge v$ & $r, 0$ & 11,99 & الديكور & r \\
\hline., 1.7 & 1, 1, 1, & 187 & 1,9 & $1 \leq, 1 r$ & $r, r$ & אי, & الملابس & $r$ \\
\hline$\cdot, 1 \leq V$ & $1, \varepsilon \otimes \wedge-$ & 189 & $\varepsilon, 0$ & $r 0, v i$ & $\bullet, r$ & $r \leqslant, 7 r$ & الموسيقى & $\varepsilon$ \\
\hline שד., & $1, \wedge \vee 1-$ & 187 & $\leq, 1$ & $\| \wedge, \vee \wedge$ & $\varepsilon, r$ & $|v, r|$ & الإضاءة & 。 \\
\hline . . ., • دال & $r, \Upsilon \circ 0-$ & $1 \leqslant v, \leqslant \leqslant q$ & $1, v$ & $1 \cdot, \Lambda$ & r. 1 & $q, \vee r$ & الماكياج & 9 \\
\hline$\cdot, 17 \leqslant$ & $1, \varepsilon \cdot 1-$ & $1.9, \vee \vee \wedge$ & $r, r$ & $r v, 19$ & $\varepsilon, r$ & $r 4, \leqslant \leq$ & التعاون & v \\
\hline צ ז , •• دال & $|r, r v|$ & 189 & $19, v$ & $1 v_{4}, \ldots$ & $r \leqslant,$. & 171,04 & الإخراج & $\wedge$ \\
\hline
\end{tabular}

من نتائج الجدول السابق يتضـح وجود فــروق ذات دلالـــة إحــصائية بـين متوسطات درجات الطلاب في القياس البعدي وفقاً لمتغير النوع (ذكور / إناث) في داني ثلاثة مهار ات هي (الديكور، الماكياج و الإكسسوار، الإخر اج ) لصالح الإناث، حيث

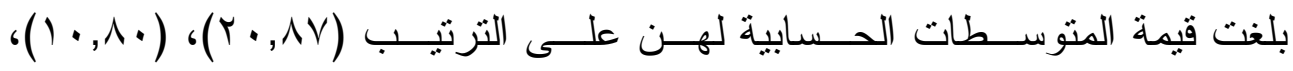

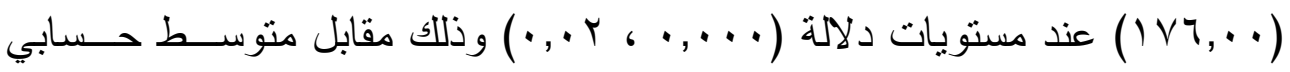

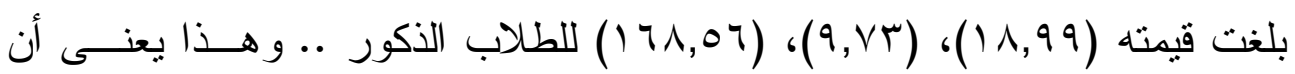
الطالبات أكثر خبرة ومعرفة بهذه المهار ات الثلاثة من الطلاب الذكور وهذا يرجع إلى طبيعة الإناث و اهتماماتهن وميولهن بالنسبة للديكور فيما يتعلق بعملية الترتيب و التزيين، و التنظيم، و التتسيق المنزلي، فهذه المهارة قد تتعلمها الإناث مــن خــلال المنزل فهي الأقرب إلى طبيعتهن بالإضافة إلى مهارة الماكياج و الإكسسوار التـي 
فعالية التلريبات المسرحية في إكساب طلاب الإعلام التربوي مهارات العدل المسرحي ــ

هي في الغالب مهارة أنثوية، فضلاً عن أن الطالبات لديها خبرة ومعرفة بها سابقة على التدريبات المسرحية وذلك كما أظهرته نتيجة القياس القبلــي • أمـــا بالنــسبة لمهارة الإخر اج المسرحي وهى المهارة التي تحتاج إلى الصبر و المثابرة وتحمـلـ تبعات العمل المسرحي ومشقاته وقيادة فريق العمل جعل الإناث أكثر اكتسابا لهــا من الطلاب الذكور الثـيء الغير مناح للطالبات الإناث قبل ذللك، ومع تـــوفر ذلــك جعل الإناتث أكثز اكتسابا لها من الذكور وهذا ما لاحظـــه الباحــث أثتـــاء فتــرة

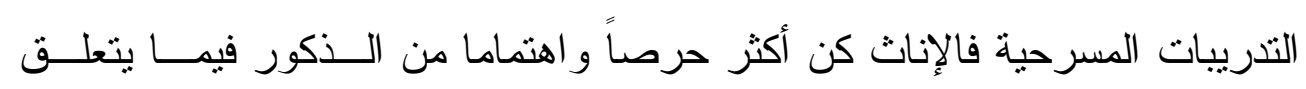
بمباشرة تصنيع الديكور ودهانه وتوزيعه على خثبة المسرح أثناء عمل البروفـات المسرحية و التو اجد المستمر مع فريق التمثيل و الإخر اج •

ومما سبق يتضتح تحقق الفرض الثاني جزئياً حيــث وجــدت فـروق بــين

متوسطات درجات الطلاب في القياس البعدي ترجع لمتغير النوع ولصالح الإنــاث في مهار ات (الديكور، و الماكياج و الإخر اج) بينما لا توجد فروق بينهما في أبعـاد مهار ات (التمثيل، المابس، الموسيقى، الإضاءة، التعاون) حيث تقاربت المتوسطات الحسابية لهم في هذه المهار ات .

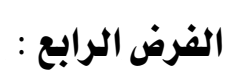

"ثوجد فروق ذات دلالة إحصائية بين متوسطات درجات الطلاب في مهار ات

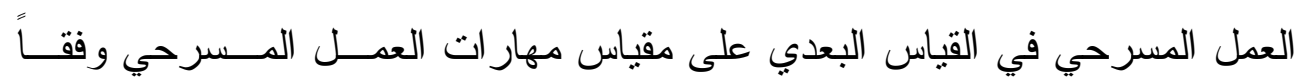
لمتغير المؤهل قبل الجامعي (تعليم فني - تعليم ثانوي عام).

للتحقق من صحة هذا الفــرض اســتخدم الباحــث اختبــار (ت) وحـسـاب

المتوسطات الحسابية و الانحر افات المعيارية كما هو مبين بالجدول التالي : 


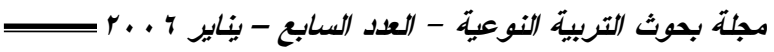

$$
\text { جدول (؟) }
$$

دلالة الفروق بين متوسطات درجات الطلاب في القياس البعدي وفقاً لمتغير المؤهل قبل الجامعي

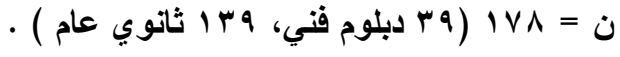

\begin{tabular}{|c|c|c|c|c|c|c|c|c|}
\hline \multirow{3}{*}{ مستوى الدلالة } & \multirow{3}{*}{ قيمة ت } & \multirow{3}{*}{ درجة الحرية } & \multicolumn{4}{|c|}{ المؤهل قبل الجامعي } & \multirow{3}{*}{ المهارة } & \multirow{3}{*}{ P } \\
\hline & & & \multicolumn{2}{|c|}{ ثانوي عام } & \multicolumn{2}{|c|}{ دبلوم فني } & & \\
\hline & & & $\varepsilon$ & 5 & $\varepsilon$ & م & & \\
\hline . & $\cdot, \varepsilon \mid V$ & VV,Trr & $\wedge, \vee$ & $\leq V, q V$ & $\mathrm{Y}, \mathrm{V}$ & $\{\wedge, 01$ & التمثيل & 1 \\
\hline · $\{\leqslant q$ & $\cdot, \vee \vee \vee ०-$ & 187 & $r, \varepsilon$ & $r \cdot, l \leq$ & $r, 1$ & $19,9 \vee$ & الايكور & r \\
\hline וזr, & ., $9 \vee \leq-$ & 187 & $r, l$ & $\mid r, q 1$ & $1, \wedge$ & rז, & الملابس & $r$ \\
\hline •,rrv & $1,1 \wedge 7$ & 187 & $\varepsilon, 9$ & $r_{0, \ldots}$ & $\varepsilon, V$ & $r q, .0$ & |الموسيقى & $\varepsilon$ \\
\hline., $01 \leqslant$ &., $70 \leq-$ & 184 & $\varepsilon, 1$ & $i \wedge, r v$ & $\varepsilon, \varepsilon$ & $i v, \wedge v$ & الإضاءة & 0 \\
\hline$\cdot, \cdot \wedge r$ & $1, v \leq \wedge-$ & 187 & 1,9 & $1 \cdot, \leqslant 4$ & r. 1 & $9, \wedge 0$ & الماكياج & 7 \\
\hline$\cdot, r \cdot l$ & $1, r \wedge \leq-$ & 187 & $r, 1$ & $r v, \cdot r$ & $\varepsilon, 1$ & Tq, & التعاون & $v$ \\
\hline$\cdot, \vee \vee q$ & $\cdot, r \wedge 1-$ & 187 & rr,. & IVr, q & $r r, r$ & IVI,Ar & الإخراج & $\wedge$ \\
\hline
\end{tabular}

من الجدول السابق يتضح عدم وجود فروق دالة إحصائية بـين متوســطات

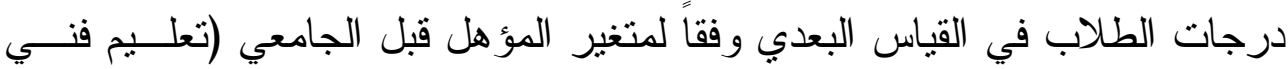
صناعي + جامعة عمالية أو تعليم فني صناعي نظام الخمس سنوات، أو معهد فني صناعي، و التعليم الثانوي العام) حيث تقاربت المتوسطات الحسابية لهـــ، فطبيحسـة التثريبات المسرحية التي تلقاها الطلاب بصرف النظر عن مؤهلهم قبل الجــامعي

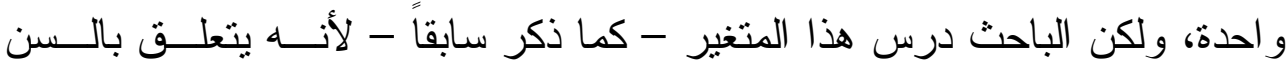

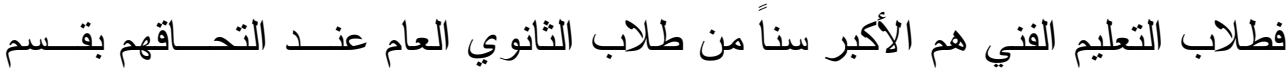

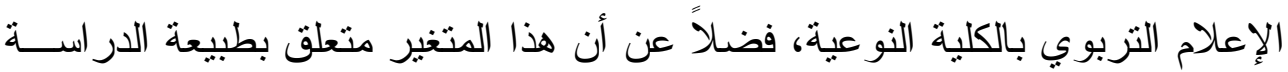
قبل الالتحاق بالكلية فدر اسة طلاب التعليم الفني متعلقة بالمهار ات و التخصــصـات العملية (ميكانيكا - سيار ات - تبريد وتكييف) أما در اسة طلاب الثانوي العام فهي 
در اسة نظرية .

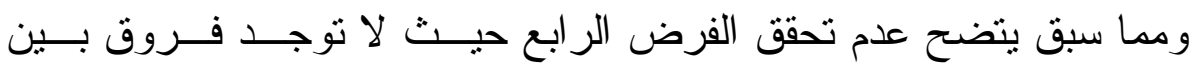

متوسطات درجات الطلاب في القياس البعدي ترجع لمتغير المؤهل قبل الجامعي .

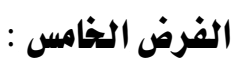

توجد فروق ذات دلالة إحصائية بين متوسطات درجات الطلاب في مهار ات

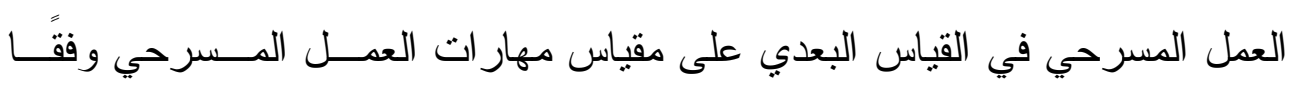
لمتغير المجمو عة التي بشارك فيها الطالب .

للتحقق من صحة هذا الفرض استخدم الباحث تحليل التباين آحادي الاتجــاه، وتم حساب قيمة (ت) وحساب المتوسطات الحسابية و الانحر افات المعيارية لأفــر اد لدائ

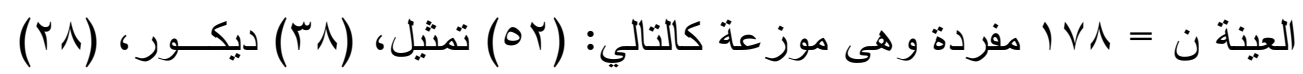

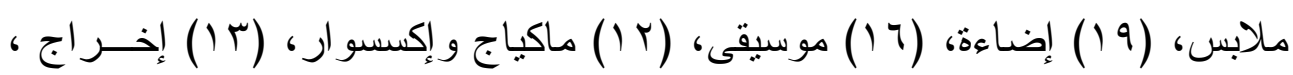
ويمكن تتاول نتائجه في الجدول التالي • 
جلول (10)

تحليل التباين أحادى الاتجاه لدلالة الفروق في المتوسطات وفقاً لمتغير المجموعة التي يشارك فيها الطالب في القياس البعدي

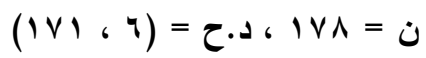

\begin{tabular}{|c|c|c|c|c|c|c|c|c|c|c|c|c|c|c|c|c|c|}
\hline \multirow[t]{2}{*}{ مستوى الالالة } & \multirow[t]{2}{*}{ ف } & \multicolumn{2}{|c|}{ الإخراج } & \multicolumn{2}{|c|}{ و الإكسسوارياج } & \multicolumn{2}{|c|}{ الموسيقى } & \multicolumn{2}{|c|}{ الإضاءة } & \multicolumn{2}{|c|}{ الملابس } & \multicolumn{2}{|c|}{ الايكور } & \multicolumn{2}{|c|}{ التمثيل } & \multirow[t]{2}{*}{ المهارة } & \multirow[t]{2}{*}{ م } \\
\hline & & $\varepsilon$ & 5 & $\varepsilon$ & 5 & $\varepsilon$ & 5 & $\varepsilon$ & 5 & $\varepsilon$ & 5 & $\varepsilon$ & 5 & $\varepsilon$ & 5 & & \\
\hline סץ •, •.دال & $r, \leqslant \vee V$ & $v, \varepsilon$ & $0 ., 95$ & $v, v$ & $\varepsilon v, I V$ & $\varepsilon, 0$ & 01,41 & 9,7 & $\varepsilon \wedge, \diamond \wedge$ & 7,7 & 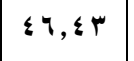 & 9,9 & צ & $v, v$ & $\leqslant ৭, \wedge r$ & التمثيل & 1 \\
\hline . . ., •دال & T,YYA & $r, \Lambda$ & $r \cdot, r \mid$ & $r, 0$ & $r, i v$ & $r, 1$ & $r_{\cdot}, \leq \leqslant$ & 1,0 & r T,Or & $r, \wedge$ & 19,94 & r, & r $1,0$. & $r, \Lambda$ & $1 \Lambda, \cdot r$ & الديكور & $r$ \\
\hline זץ •, •.دال & $r, 0 \leqslant r$ & $r, r$ & Ir,qr & 1,1 & $1 \leqslant, 01$ & 1,0 & $1 \leqslant, 0$. & 1,1 & $I \leqslant, r V$ & 1,9 & $1 \leqslant, 0$. & r, \{ & $1 \%, 90$ & $r, \cdot$ & ir,vo & الملابس & $r$ \\
\hline . . , . •دال & V,OTr & $\varepsilon, r$ & $r v, . \wedge$ & $\{, 0$ & ro,qr & $\cdot, 9$ & r.,0. & 0,0 & $r \otimes, r v$ & $r, \Lambda$ & $r \leq, 0$. & ؛ & $r r, 11$ & $\leq, 9$ & $r \leqslant, 0 \wedge$ & الموسيقى & $\varepsilon$ \\
\hline ז +., , •دال & $r, v \cdot r$ & $\varepsilon, 1$ & 19, & $\varepsilon, r$ & $\wedge \wedge, \wedge r$ & $r, r$ & 11, & $\{, 1$ & $r i, \vee q$ & צ & IV,Ar & $r, r$ & 18,17 & $\varepsilon, r$ & $I V, \leqslant r$ & الإضاءة & 0 \\
\hline ^ • ., . •دال & r,q৭r & 1,1 & $1 \cdot, 9 r$ & $\cdot, \cdot$ & ir, & 1.9 & $9, \wedge \wedge$ & $1, v$ & 9,01 & $1 . \varepsilon$ & $1 \cdot, \times 9$ & 1,9 & 9,90 & $r . r$ & $1 \cdot, r r$ & الماكياج & 7 \\
\hline . ,q4q & ., Yq & r, & $r v, 10$ & $r, \uparrow$ & $r v, \Delta \wedge$ & $r, \tau$ & $r v, r i$ & r, & $m q, v \leq$ & $r,$. & rq,rr & $r$ & r4,90 & $\varepsilon, r$ & r r,vo & التعاون & $\mathrm{V}$ \\
\hline -, & $1, \wedge \wedge \wedge$ & $r_{1}, q$ & IVq,q & IV, $\varepsilon$ & IVV,YO & $i r, v$ & $1 A r, 04$ & $r, v$ & $1 V V, 90$ & $1 \wedge, \varepsilon$ & $I V \cdot, r q$ & rr, & 174,47 & $r_{0, r}$ & $\mid v \cdot, \Delta \wedge$ & الإخراج & $\wedge$ \\
\hline
\end{tabular}


فعالية التلدرييات المسرحية في إكساب طلاب الإعلام التربوي مهارات العمل المسرحي ــ من نتائج الجدول السابق يتضـح وجود فــروق ذات دلالـــة إحــصائية بــين متوسطات درجات الطلاب في القياس البعدي وفقاً لمتغير المجموعة التي يـشارك فيها الطالب في (T) مهار ات هي (التمثيل، الديكور، الملابس، الموسيقى، الإضـاءة، الماكياج) ويمكن توضيح ذلك كما يلي :

- بمقارنة المتوسطات الحسابية فنجد أن الطلاب مجموعة الموسيقى اكتسبوا مهارة التمثيل يليه الطلاب مجموعة الإخر اج المسرحي ثم التمثيل، الإضاءة، الماكياج و الإكسسوار، الديكور وذلك عند مستوى دلآله (0 • , •) . - اكتسب طلاب مجمو عة الإضـاءة مهارة الديكور يليــهـ الطــلاب مجموعـــة

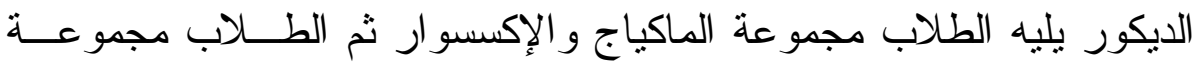
الموسيقى ثم الطلاب مجموعة الإخر اج المسرحي ثـــم الطــلاب مجموعـــة الملابس ثم الطلاب مجموعة التمنيل عند مستوى دلالة ( . ., •) . - بينما جاء ترتيب اكتشاب مهارة الملابس وفقاً للمجموعــة المـشـارك فيهــا الطالب كالتالي : مجموعــة طــلاب (الماكيــاج و الإكسـسـوار ، الملابـس

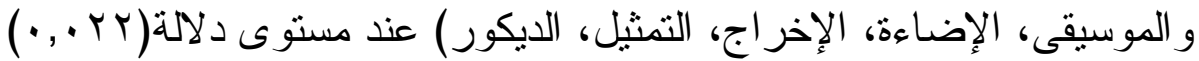
- كما أكتسب الطلاب مجموعة الموسيقى مهارة الموسيقى يليه طلاب مجموعة

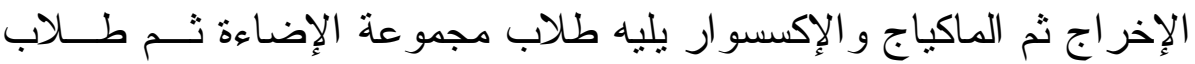
مجمو عة التمثيل يليه الطلاب مجموعة الملابس عند مستوى دلالة ( . . . ). - اكتسب الطلاب مهارة الإضاءة المسرحية ولصالح الطلاب مجموعة الإضاءة يليه طلاب مجموعة الإخر اج، ثم الماكياج و الإكسسوار، ثم الموســـقـى ثـــ الطلاب مجموعة الملابس، ثم مجموعة التمثيل ثم الطلاب مجموعة الديكور عند مستوى دلالة (r (., ••) . 


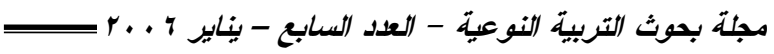

- اكتسب الطلاب مهارة الماكياج و الإكسوار وكانت لصالح طلاب مجموعة الماكياج و الإكسسو ار يليه الطلاب مجموعة الإخر اج المسرحي ثم الطــلاب مجموعة الملابس، التمثيل، الديكور ، الموسيقى عند مستوى دلاله (1 . , • ) . - بينما لا توجد فروق دالة إحصائية بين متوسطات درجات الطلاب - فــي القياس البعدي - على مقياس مهار ات العمل المسرحي في مهارتي التعاون، الإخر اج المسرحي حيث تقاربت المتوسطات الحسابية لهم.

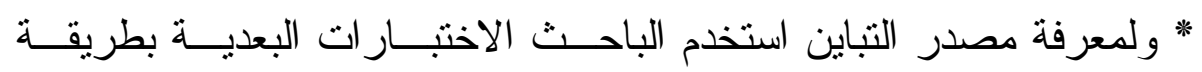
(طريقة أقل فرق معنوي)، و الذي يمكن تتاول نتائجه في الجدول التالي (LSD) 
جدول (17) مصدر التباين بين المجموعات وفقا لمتغير المجموعة التي يشارك فيها الطالب .

\begin{tabular}{|c|c|c|c|c|c|c|c|c|c|c|c|c|c|}
\hline \multicolumn{12}{|c|}{ المجموعة (ل ) } & \multirow{3}{*}{ |المجموعة (1) } & \multirow{3}{*}{ المهارة } \\
\hline \multicolumn{2}{|c|}{ إخراج } & \multicolumn{2}{|c|}{ ماكياج و إكسسو ار } & \multicolumn{2}{|c|}{ موسيقي } & \multicolumn{2}{|c|}{ إضاعة } & \multicolumn{2}{|c|}{ ملابس } & \multicolumn{2}{|c|}{ ديكور } & & \\
\hline$د$ & $1-5$ & $د$ & $1-J$ & $د$ & $1-J$ & $د$ & $1-J$ & $د$ & $1-J$ & $د$ & $1-J$ & & \\
\hline צוצד & $1,1 .-$ & $\cdot, r \cdot \theta$ & צו & .,Or. & $1, \leqslant 9-$ &., 070 & $1, r_{0}$ &.,$\cdot v \leq$ & $r, \varepsilon$. & $\cdot, \ldots r$ & $0,1 \mathrm{~V}$ & تمثيل & \multirow{6}{*}{ | } \\
\hline., $.1 \mathrm{~V}$ & $8, Y V-$ &.,$r \leqslant q$ & $r, 01-$ &.,$\ldots 7$ & $7,70-$ &., .10 & $r, q r-$ & .,rvq & $1, v v-$ & - & - & ديكور & \\
\hline., .99 & $\leq, \leq 9-$ & $\cdot, \vee_{91}$ & $\cdot, \mathrm{V} \leq-$ &., .00 & $£, \wedge \wedge-$ & $\cdot, r v i$ & Y,10- & - & - & - & - & ملابس & \\
\hline$\cdot,\{Y 1$ & $r, r \leq-$ & צדו & $1, \leqslant 1$ & $\cdot, r 19$ & $r, v r_{-}$ & - & - & - & - & - & - & إضاءة & \\
\hline$\cdot, r \leq Y$ & $\cdot, r q$ & $\cdot, 1 \wedge$ & $\varepsilon, 10$ & - & - & - & - & - & - & - & - & موسيقى & \\
\hline$\cdot, r \leq Y$ & $r, v \tau_{-}$ & - & - & - & - & - & - & - & - & - & - & ماكياج و إكسسو ار & \\
\hline., .11 & r,rq- & .,.,r & $r, 10-$ & .,...v & $r, \varepsilon r-$ &.,$\ldots$ & $r, 01-$ &.,$\ldots 9$ & $1,91-$ &.,$\ldots$ & $r, \varepsilon \wedge-$ & تمثيل & \multirow{6}{*}{ r - الايكور - } \\
\hline . & 1,19 & $\cdot, \mathrm{V} \leq \varepsilon$ & 更, & $\cdot, r \leqslant q$ & $1, .7$ & $\cdot, 9 \vee 7$ & $\cdot, \cdot r_{-}$ & $\cdot, \cdot \leqslant Y$ & $1,0 \mathrm{~V}$ & - & - & ديكور & \\
\hline$\cdot, V) \leq$ &., $\mathrm{r} \wedge-$ &.,$r \leqslant 7$ & $1, r \leqslant-$ &., 099 &., $01-$ &.,.$\wedge r$ & $1,7 .-$ & - & - & - & - & ملابس & \\
\hline$\cdot, r V r$ & $1, r Y$ & .,vor & צ &.,$Y 9 q$ & $1, .9$ & - & - & - & - & - & - & إضاءة & \\
\hline., 91. &., 14 & ., Ory &., $\mathrm{Vr}-$ & - & - & - & - & - & - & - & - & موسيقي & \\
\hline$\cdot, \leqslant \wedge \vee$ &., 14 & - & - & - & - & - & - & - & - & - & - & ماكياج و إكسسوار & \\
\hline$\cdot, \vee \vee \wedge 1$ &., $1 V-$ &., 199 & $\cdot, \wedge r-$ &., $19 r$ & $\cdot, \mathrm{v} \bullet-$ & $\cdot, Y 01$ & - &., $11 \mathrm{r}$ & $\cdot, \mathrm{v} \bullet-$ &., .74 & $\cdot, \wedge$. & تمثيل & \multirow{6}{*}{ | - الملابس| } \\
\hline . Irr &., $91-$ &., .10 & $1,7 \leq-$ &., .1 . & $1,00-$ &., .14 & $1, \leqslant Y-$ & $\cdot, \ldots r$ & $1,00-$ & - & - & ديكور & \\
\hline - rar & $\cdot, 0 \wedge$ & $\cdot, 9 \cdot \leq$ & $\cdot, \cdot \wedge-$ & $1, \ldots$ & $\cdot, \ldots$ & $\cdot, \wedge$ ^० & $\cdot, 1 T$ & - & - & - & - & ملابس & \\
\hline . , or & ., $\leqslant 0$ & $\cdot, \vee \vee \vee r$ & $\cdot, r)-$ & $\cdot, \wedge \leq \vee$ &., $1 \mathrm{r}_{-}$ & - & - & - & - & - & - & إضاءة & \\
\hline$\cdot, \leqslant \leqslant r$ & $\cdot, 0 \wedge$ & $\cdot, 914$ & $\cdot, \cdot \wedge-$ & - & - & - & - & - & - & - & - & موسيقى & \\
\hline$\cdot, \leqslant 1 Y$ & .,74 & - & - & - & - & - & - & - & - & - & - & ماكياج و إكسسو ار & \\
\hline
\end{tabular}


تابع جدول (1 1 ) مصدر التباين بين المجموعات وفقا لمتغير المجموعة التي يشارك فيها الطالب .

\begin{tabular}{|c|c|c|c|c|c|c|c|c|c|c|c|c|c|}
\hline \multicolumn{12}{|c|}{ المجموعة (ل ) } & \multirow{3}{*}{ المجموعة (1) } & \multirow{3}{*}{ المهارة } \\
\hline \multicolumn{2}{|c|}{ إخراج } & \multicolumn{2}{|c|}{ ماكياج و إكسسوار } & \multicolumn{2}{|c|}{ موسيقي } & \multicolumn{2}{|c|}{ إضاعة } & \multicolumn{2}{|c|}{ ملابس } & \multicolumn{2}{|c|}{ ديكور } & & \\
\hline$د$ & $1-J$ & $د$ & $1-J$ & $د$ & $1-j$ & $د$ & $1-J$ & $د$ & $1-j$ & $د$ & $1-3$ & & \\
\hline$\cdot, \cdot v_{1}$ & $r, 0 .-$ & $\cdot, r \leqslant v$ & $1, r \leq-$ & $\cdot, \ldots$ & $7 \cdot, 9 r-$ &., 0.7 &.,$\vee \vee 9-$ &., $9 \leq 1$ & $\cdot, \cdot \wedge$ & $\cdot, I r r$ & $1, \leqslant v$ & تمثيل & \multirow{6}{*}{ ع - الموسيقى } \\
\hline.,$\ldots 7$ & $r, q v-$ &., $.0 \mathrm{~V}$ & $r, \wedge,-$ &,$\ldots$ & $\Lambda, r q-$ &.,.$\times 1$ & Y,YY- & $\cdot, r \cdot \Lambda$ &.,$r q-$ & - & - & ديكور & \\
\hline$\cdot, \cdot \wedge 0$ & $r, \diamond \wedge-$ & • & $1, \leqslant r-$ & $\cdot, \cdots$ & $v, \ldots-$ &., 011 & $\cdot, \wedge \vee-$ & - & - & - & - & ملابس & \\
\hline$\cdot$, Y^४ & $1, \times 1-$ & $\cdot, \vee \vee \mu$ & $\cdot, \infty \Delta-$ & $\cdot, \cdots$ & $7,11-$ & - & - & - & - & - & - & إضاءة & \\
\hline$\cdot, \cdots \wedge$ & $\leq, \leq r$ & $\cdot, \ldots 1$ & $0,0 \wedge-$ & - & - & - & - & - & - & - & - & موسيقى & \\
\hline., $01 \leq$ & $1,19-$ & - & - & - & - & - & - & - & - & - & - & ماكياج و إكسسوار & \\
\hline$\cdot, \cdot \vee 9$ & $r, 19-$ & $\cdot, r V r$ & $1, \leqslant 1-$ & $\cdot, r q \leq$ & $1, r \cdot-$ & $\cdot, \ldots$ & $\varepsilon, r v-$ &., $7 \vee 1$ & ., ६.- & $\cdot, \vee \vee \neg$ & $\cdot, r V$ & تمثيل & \multirow{6}{*}{ ه- الإضاءة } \\
\hline., $.0 \mathrm{~V}$ & $r, \leq ૫_{-}$ & $\cdot, r \cdot v$ & $1,7 \wedge-$ & $\cdot, r r$. & $1, \leqslant \vee-$ & $\cdot, \ldots$ & 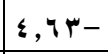 &., 0.7 &., $74-$ & - & - & ديكور & \\
\hline$\cdot, \mid \wedge r$ & $1, \vee \vee 9-$ & $\cdot, \leqslant 7 \leqslant$ & $1, .1-$ & .,OYr & $\cdot, \wedge \cdot-$ & $\cdot, \ldots 1$ & $r, q \vee-$ & - & - & - & - & ملابس & \\
\hline ., Irr & $r, I v-$ & $\cdot, \cdot \leq 4$ & $r, 97$ & $\cdot, \cdot r_{1}$ & $r, 17$ & - & - & - & - & - & - & إضاعة & \\
\hline$\cdot, 0.1$ &., $99-$ & $\cdot, \wedge 94$ & $\cdot, r_{1-}$ & - & - & - & - & - & - & - & - & موسيقى & \\
\hline ס ק ז, & $\cdot, \vee \wedge \wedge-$ & - & - & - & - & - & - & - & - & - & - & ماكياج و إكسسوار & \\
\hline •, rrA &., $79-$ & $\cdot, \ldots \varepsilon$ & $1, \vee \vee-$ &., 011 & צ & $\cdot, 199$ & $\cdot, 10$ &.,$Y M$ &., $00-$ & $\cdot, \leqslant \wedge r$ & $\cdot, r \wedge$ & تمثيل & \multirow{6}{*}{ و الإكسسوار - الماكياج } \\
\hline., 1.9 & $\cdot, 9 \wedge-$ & $\cdot, \ldots 1$ & $r, . .-$ & $\cdot, \wedge 9 \wedge$ & $\cdot, \cdot v$ & $\cdot,\{\wedge \wedge$ & $\cdot, r v$ &.,.,${ }^{\prime}$ & $\cdot, \wedge \leq-$ & - & - & ديكور & \\
\hline$\cdot, \wedge$ ४ & $\cdot, 1 \leq-$ & $\cdot, \cdot 7 \leq$ & $1, Y_{1}-$ & • & $\cdot, 91$ & $\cdot, \cdot r r$ & $1, r_{1}$ & - & - & - & - & ملابس & \\
\hline$\cdot, \cdot \leq 9$ & $1, r \leq-$ & $\cdot, \ldots 1$ & $r, \varepsilon r-$ & $\cdot, 7 \leq \leqslant$ & $\cdot, r \cdot-$ & - & - & - & - & - & - & إضاعة & \\
\hline$\cdot, 149$ & $1, .0-$ & $\cdot, \ldots \leq$ & $r, 1 r-$ & - & - & - & - & - & - & - & - & موسيقي & \\
\hline., 107 & $1, \cdot 1$ & - & - & - & - & - & - & - & - & - & - & ماكياج و إكسسوار & \\
\hline
\end{tabular}


فعالية التلـريبات المسرحية في إكساب طلاب الإعلام التربوي مهارات العمل المسرحي

من الجدول السابق يتضح وجود فروق ذات دلالة إحصائية فــي مهــار ات العمل المسرحي يمكن توضيحها كالآتي :

ا- مهارة التمثيل :وجود فروق دالة إحصائياً في مهارة التمثيل لصالح طلاب مجموعات ( التمثيل ، الموسيقى ، الإخــراج )عــن الطــلاب مجموعــة

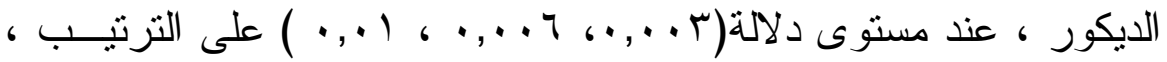
كما وجدت فروق في هذه المهارة لصالح طلاب الموسيقى عـن طـلاب الملابس عند مستوى دلالة (00. . •) .

r- مهارة الديكور : وجود فروق ذات دلالة إحصائية بين الطلاب مجموعــة التمثيل وطلاب مجموعات (الديكور ، الملابس ، الإضـاءة ، الموســيقى ، و الماكياج و الإكسسو ار، الإخر اج) في مهــارة الــديكور لـصـالح طـلاب مجموعات (الديكور ، المالابـس ، الإضـــاءة ، الموســيقى ، الماكيــاج ،

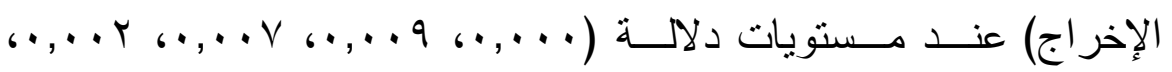
( , • ) على الترتيب . وجدت فروق دالة إحصائياً بين طــلاب مجموعــة الديكور وطلاب مجموعة المابس لصالح الطلاب مجموعة الديكور عنــد

$$
\text { مستوى دلالة (ع •, (•) }
$$

ب- مهارة الملابس : وجدت فروق ذات دلالة إحصائية بين الطلاب مجموعــة الديكور و الطلاب مجموعات (الملابس ، الإضناءة ، الموسيقى ، الماكيــاج و الإكسسو ار ) في مهارة الملابس لصالح الأخيرة عنــــ مسستويات دلالـــة

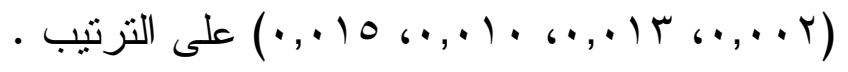
ع- مهارة الموسيقي : وجدت فروق دالة إحصائياً في مهارة الموســيقى بـين الطلاب مجمو عة الموسيقى وطلاب مجمو عات (التمثيل، الديكور، الملابس، 
مجلة بحوث التربية النوعية - العدد السابع - يناير r ..r بـ

الإضـاءة، الماكياج و الإكسسوار، الإخر اج المـسرحي) لــــالح الطــلاب

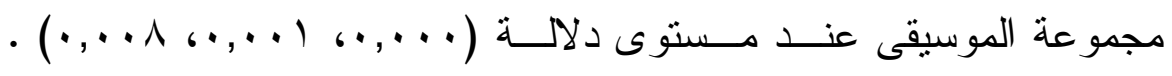

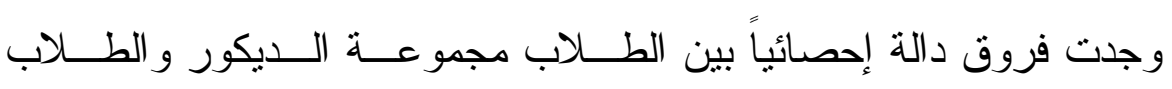

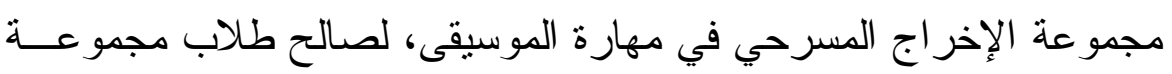

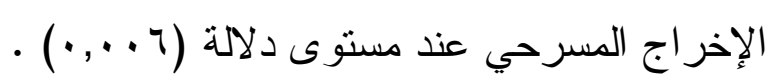

ه- مهارة الإضاءة المسرحية : وجدت فروق دالة إحصائياً في مهارة الإضاءة

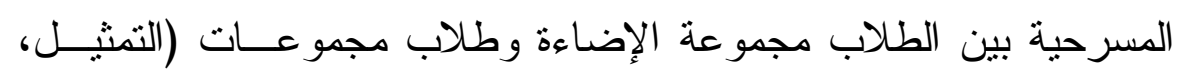

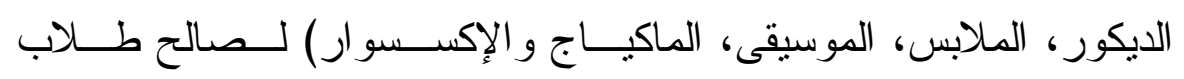

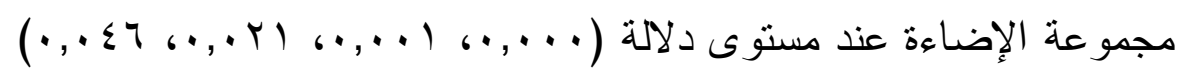
على التزتيب اعلى الإن

؟- مهارة الماكياج و الإكسسوار : وجدت فروق دالة إحــصائياً فــي مهـارة

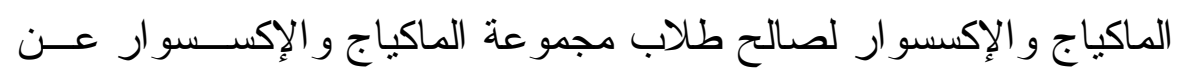

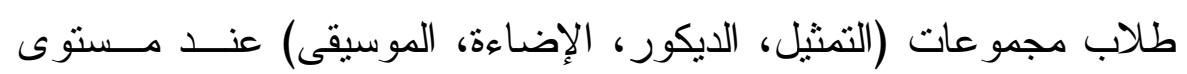

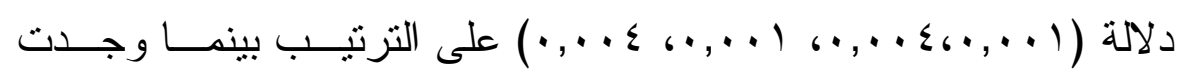
فروق دالة إحصائياً في هذه المهارة لصالح الطلاب مجموعة الملابس عن

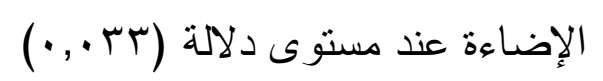

ومما سبق ووفقاً لهذا الفرض فقد وجدت فروق دالة إحصائياً بين منوسطات

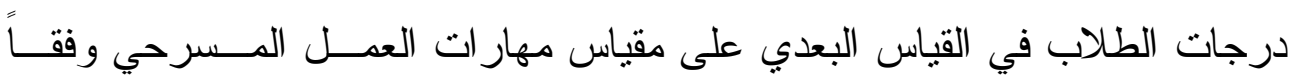

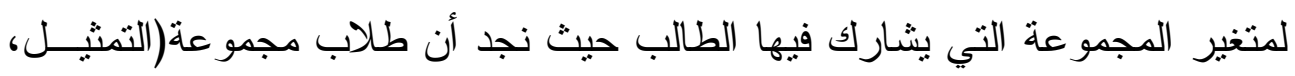

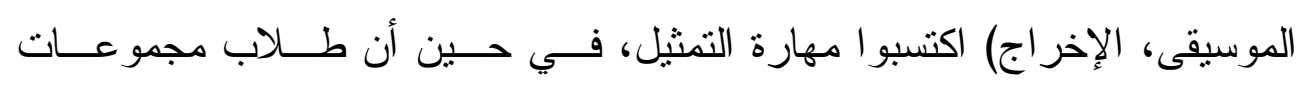

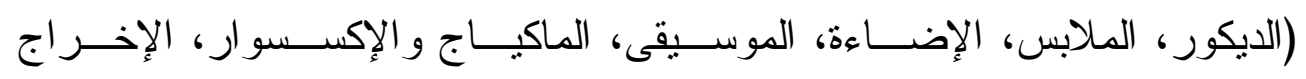

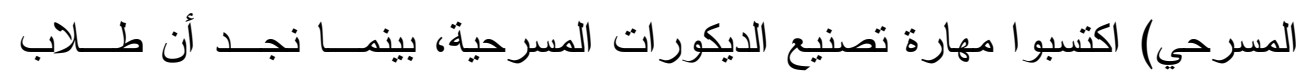


فعالية التلريبات المسرحية في إكساب طلاب الإعلام التربوي مهارات العدل المسرحي

مجموعات (الملابس، الإضناءة، الموسيقى، الماكياج و الإكسسوار) اكتسبو ا مهــارة تحضير الملابس المسرحية، أما طلاب (الموسيقى، الإخراج) فقد اكتـسبو ا مهــارة الموسيقى، في حين اكتسب طلاب مجمو عة الإضـاءة مهارة الإضــاءة المـسرحية، و اكتسب طلاب مجمو عة الماكياج و الملابس مهارة الماكياج و الملابس .

\section{الثرض السادس :}

"توجد فروق ذات دلالة إحصائية بين متوسطات درجات الطلاب في مهار ات

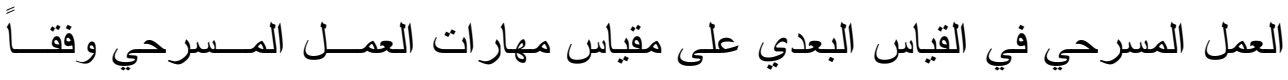
لمتغير مكان الكلية" .

للتحقق من صحة هذا الفرض استخدم الباحث اختبار تحليل التباين أحــادى الاتجاه، وحساب المتوسطات الحسابية و الانحر افات المعيارية، وقيمة ف، ودرجات الحرية ومستويات الدلالة لأفر اد العينة ن = (IVA) مفردة موزعــة علـى ثـلاث كليات (كلية التربية النوعية بالمنصورة (VI) مفردة، (V9) مفردة ميــت غمــر، (Y^) مفردة منية النصر )، ويمكن تتاول نتائجه في الجدول التالي ل 


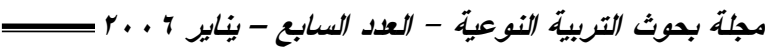

$$
\text { جدول (iv) }
$$

تحليل التباين آحادي الاتجاه لالاله الفروق بين متوسطات درجات الطلاب في القياس البعدي

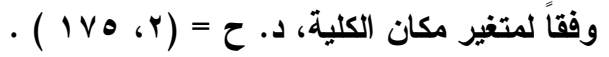

\begin{tabular}{|c|c|c|c|c|c|c|c|c|c|}
\hline \multirow{3}{*}{ مستوى الالاحة } & \multirow{3}{*}{ قيمة ف } & \multicolumn{6}{|c|}{ الكلية } & \multirow{3}{*}{ المهارة } & \multirow{3}{*}{ p } \\
\hline & & \multicolumn{2}{|c|}{ منية النصر } & \multicolumn{2}{|c|}{ ميث غمر } & \multicolumn{2}{|c|}{ المنصورة } & & \\
\hline & & $\varepsilon$ & p & $\varepsilon$ & s & $\varepsilon$ & s & & \\
\hline., .91 & $r, r \circ q$ & $9, \wedge$ & $\leqslant 0, Y_{0}$ & $\Lambda, r$ & $\leqslant 9,17$ & $v, 0$ & $\varepsilon \wedge,+1$ & التمثيل & 1 \\
\hline., 901 &., .01 & $r, q$ & $19, \wedge 9$ & $r, v$ & $r \cdot, 11$ & $r, \Lambda$ & $r \cdot, \ldots$ & الاديكور & $r$ \\
\hline$\cdot, \wedge \varepsilon$. &., $1 \vee 0$ & $r, 1$ & $1 r, v q$ & $r, \cdot$ & $1 \varepsilon, \ldots$ & $r, 1$ & $M r, \wedge r$ & | الملابس & $r$ \\
\hline מr & $r, 11 \wedge$ & $\theta, r$ & rr,人т & $\varepsilon, \wedge$ & Y०,१ & $\varepsilon, \wedge$ & $r \leqslant, 97$ & الموسبقى & $\varepsilon$ \\
\hline ץ ؛ . , . داله & $r, Y r$. & $\varepsilon, r$ & 17,81 & $\varepsilon, r$ & $1 \wedge, 9 \vee$ & $r, q$ & $1 \wedge, \cdot v$ & |الإضاءة & - \\
\hline$\cdot, v \leq r$ & $\cdot, r q q$ & $r, \cdot$ & $1 \cdot, r_{1}$ & $r, l$ & $1 \cdot, r \leq$ & 1,1 & $1 \cdot, \leq 4$ & الماكياج & 7 \\
\hline זד, • & $\cdot, r \vee I$ & $r, q$ & $r v, 11$ & $\varepsilon$, & צ & $r, T$ & $r q, 99$ & التعاون & $v$ \\
\hline$\cdot, Y r V$ & $1, \varepsilon 9 V$ & Y I, & $177, \wedge \mathrm{r}$ & $r \leqslant, 0$ & $1 \vee 0,11$ & 11,9 & IVr,rr & الإخر اج & $\Lambda$ \\
\hline
\end{tabular}

من نتائج الجدول السابق يتبين عدم وجود فروق ذات دلالة إحــصائية بـين متوسطات درجات الطلاب في القياس البعدي بعد إجراء التدريبات المسرحية ترجع لمتغير مكان الكلية النوعية سواء كانت بالمنصورة أو ميت غمر أو منية النـصر حيث ثقاربت المتوسطات الحسابية، وذلك ما عدا مهارة الإضاءة المسرحية فهـي

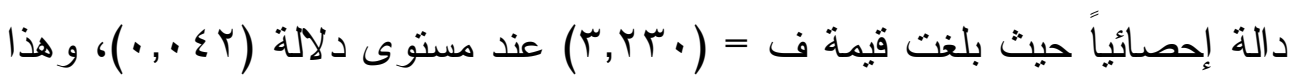
يدل على أن التدريبات المسرحية ساعدت الطلاب على اكتساب مهــار ات العمـلـل

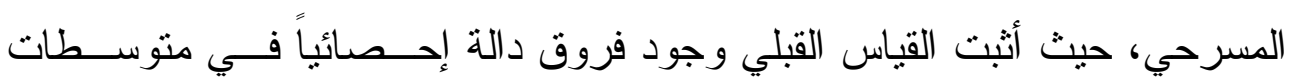
درجات الطلاب نرجع لمتغير مكان الكية النوعية ولصالح طلاب الإعلام التربوي بالمنصورة - في الثمانية مهار ات - دون طلاب الإعلام التربوي بميت غمر ومنية النصر ، وبعد التجربة المسرحية وتدريب الطلاب على مهار ات (التمثيل، الديكور، المهلابس، الموسيقى، الإضـاءة، الماكياج، التعاون، الإخراج ) ثقاربت المتوســطات الحسابية للطلاب ككل مما يدل على فعالية التذريبات المسرحية * ولمعرفة مصدر 
فعالية التلدييات المسرحية في إكساب طلاب الإعلام التربوي مهارات الععل المسرحي ــ التباين استخدم الباحث الاختبار ات البعدية بطريقة (LSD) طريقة أقل فرق معنوي و الذي يمكن تتاول نتائجه في الجدول التالي : جدول (11)

مصدر التباين لالالة الفروق بين المتوسطات فى القياس البعدى وفقاً لمتغير مكان الكلية .

\begin{tabular}{|c|c|c|c|c|c|}
\hline \multicolumn{4}{|c|}{ الكلية (ل) } & \multirow{3}{*}{ الكلية (1) } & \multirow{3}{*}{ المهارة } \\
\hline \multicolumn{2}{|c|}{ منية النصر } & \multicolumn{2}{|c|}{ ميت غمر } & & \\
\hline د & $1-J$ & د & $1-J$ & & \\
\hline 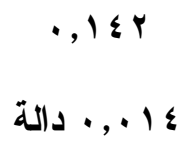 & $\begin{array}{l}1, r q \\
\text { T,Y }\end{array}$ & $\begin{array}{c}\cdot, \operatorname{Ar} \\
-\end{array}$ & $\begin{array}{c}\cdot, 9 \cdot- \\
-\end{array}$ & ميث غمر المنصورة & الإضاءة \\
\hline
\end{tabular}

من نتائج الجدول السابق يتضح وجود فروق دالة إحــصائياً علـــى مقيــاس

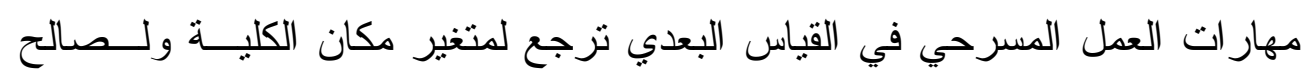

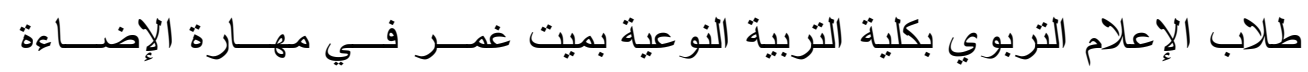

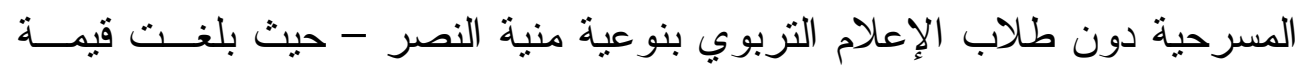

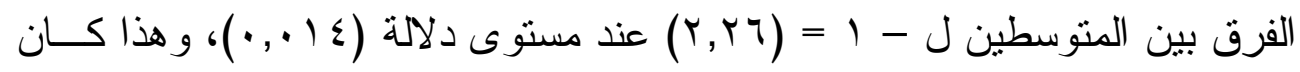

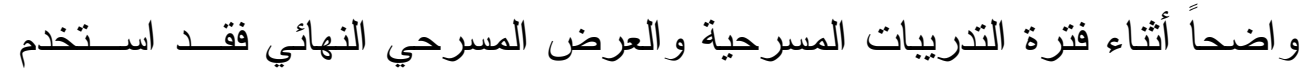

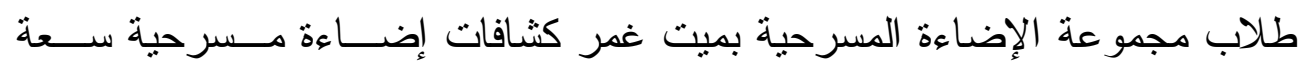

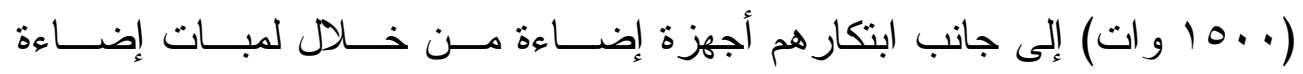
( . . . و وات) ووضعها في علب السمن الفارغة المثقوبة من الخلف و المتصلة بفيشه

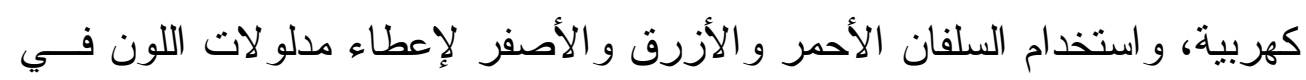
الإضاءة، حسب الاحتياجات الدر امية للمشاهد المسرحية، بعكس طلاب منية النصر الذين استخدمو المبات الإضـاءة العادية وكثافات الإضـــاءة الموجــودة بالمــدرج 


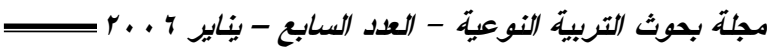

ووضع عليها السلفان الأحمر و الأزرق بما يخدم متطلبات المشاهد الدر اميــة فــي العرض المسرحي المقدم (نوبة شجاعة) .

\section{الفرض السابع : - (ابع}

"توجد فروق ذات دلالة إحصائية بين متوسطات درجات الطلاب في القياس

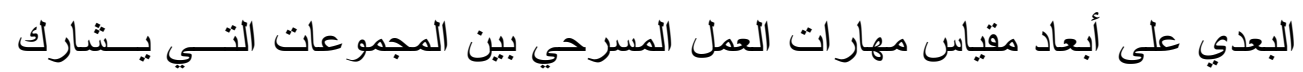

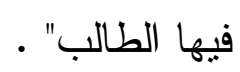

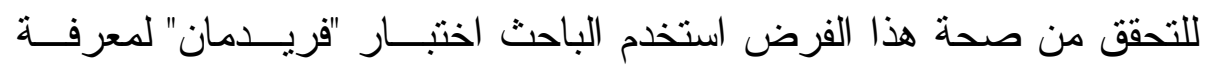
الفروق بين المنوسطات الحسابية للطلاب في مهار ات العمل المسرحي للعينة ككل

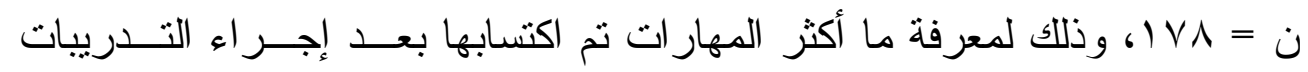
المسرحية، ويمكن تتاول نتائجه في الجدول التالي :

جدول (19)

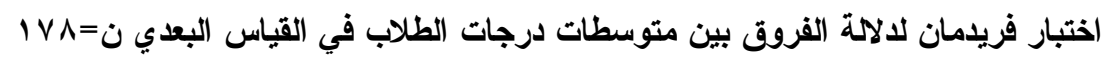

\begin{tabular}{|c|c|c|c|c|}
\hline \multirow{2}{*}{ متوسط الترتيبات } & الاحمر اف المعياري & المتوسط & \multirow{2}{*}{ المهارة } & \multirow{2}{*}{ م } \\
\hline & $\varepsilon$ & r & & \\
\hline r &., 00 & $r, r_{1}$ & التمثيل & 1 \\
\hline$\varepsilon, \varepsilon$ &., 04 & & الديكور & r \\
\hline $0, \leq \leqslant$ &., 01 & $r, \leqslant V$ & الملابس & $r$ \\
\hline$r, r v$ & $\cdot, 71$ & $r, 10$ & الموسيقى & $\varepsilon$ \\
\hline$r, 9 \wedge$ & $\cdot, v$. & $r, . \varepsilon$ & الإضاءة & 0 \\
\hline $0, \leqslant r$ & סד, • & $r, \leqslant \varepsilon$ & الماكياج & 9 \\
\hline ס ק & r & $r, 7 q$ & التعاون & $v$ \\
\hline$\varepsilon, r q$ & .,$\leqslant$ & r,rr & الإخراج & $\wedge$ \\
\hline
\end{tabular}


فعالية التلديبات المسرحية في إكساب طلاب الإعلام التربوي مهارات العدل المسرحي

من نتائج الجدول السابق يتضح وجود فــروق ذات دلالـــة إحــصائية بــين

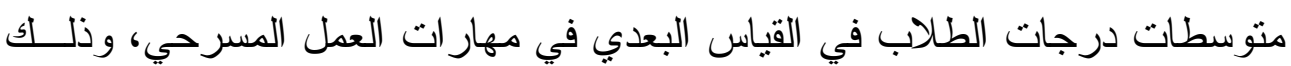

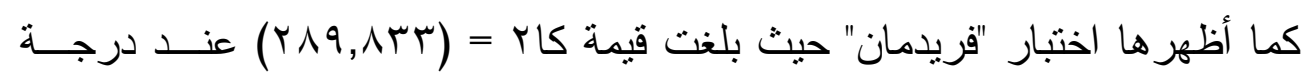

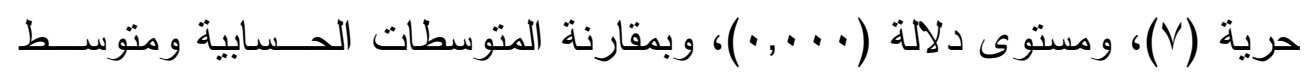

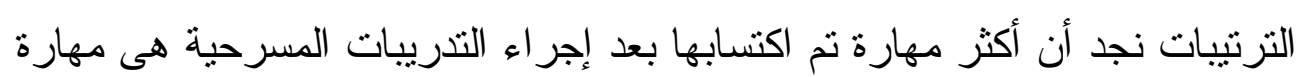

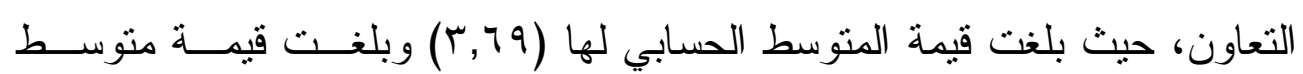

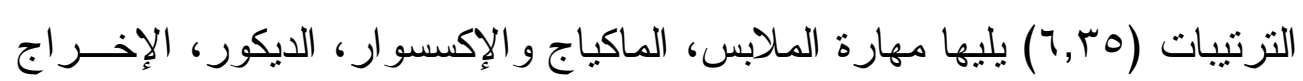

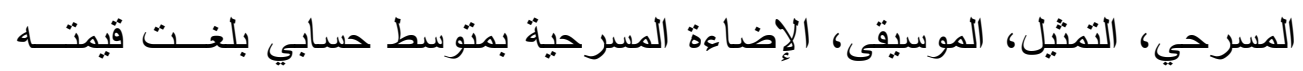

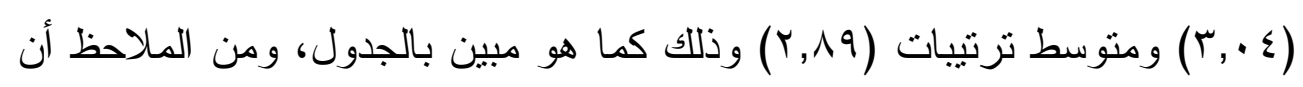

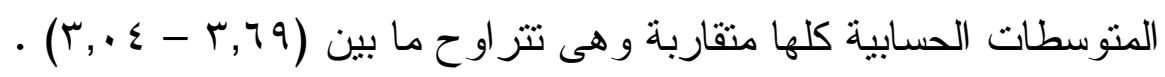
ولمعرفة دلالة الفروق بين منوسطات درجات الطلاب نم إجر اء اختبار (ت)

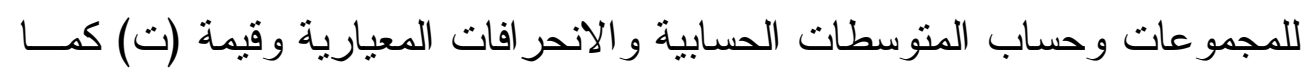
هو مبين بالجدول التالي : 


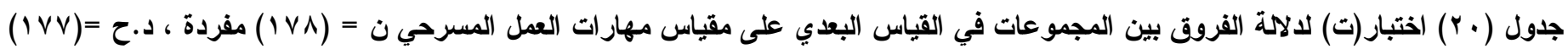

\begin{tabular}{|c|c|c|c|c|c|c|c|c|c|c|c|c|c|c|c|}
\hline \multicolumn{2}{|c|}{ الإخراج } & \multicolumn{2}{|c|}{ التعاون } & \multicolumn{2}{|c|}{ الماكياج } & \multicolumn{2}{|c|}{ الإضاءة } & \multicolumn{2}{|c|}{ الموسيقى } & \multicolumn{2}{|c|}{ الملابس } & \multicolumn{2}{|c|}{ الايكور } & \multirow{2}{*}{ قيمة ت ت المهارة } & \multirow{2}{*}{$p$} \\
\hline$\varepsilon$ & م & $\varepsilon$ & م & $\varepsilon$ & م & $\varepsilon$ & م & $\varepsilon$ & م & $\varepsilon$ & م & $\varepsilon$ & م & & \\
\hline $\begin{array}{l}., 00 \\
\leqslant r \\
., \ldots\end{array}$ & $\begin{array}{c}r, r_{1} \\
r, r r \\
0, V Y,-\end{array}$ & $\begin{array}{l}\cdot, 00 \\
\cdot, r, \\
\cdot, \ldots\end{array}$ & $\begin{array}{c}r, r 1 \\
r, r q \\
\mid r, .0 r-\end{array}$ & $\begin{array}{c}\cdot, 00 \\
\cdot, 70 \\
\cdot, \cdots\end{array}$ & $\begin{array}{l}r, r_{1} \\
r, \varepsilon \leq \\
0, r_{.}-\end{array}$ & $\begin{array}{l}\cdot, \infty \\
\cdot, v \cdot \\
\cdot, \ldots\end{array}$ & $\begin{array}{l}r, r) \\
r, \cdot \varepsilon \\
r, \Lambda \cdot r\end{array}$ & $\begin{array}{l}\cdot, 00 \\
\cdot, 71 \\
1+9\end{array}$ & $\begin{array}{l}r, Y 1 \\
r, 10 \\
1,\{\wedge 0\end{array}$ & $\begin{array}{l}., 00 \\
\cdot, 01 \\
., \ldots\end{array}$ & $\begin{array}{c}r, r) \\
r, \leqslant v \\
\Lambda, r r q-\end{array}$ & $\begin{array}{l}., 00 \\
., 04 \\
\cdot, \ldots \varepsilon\end{array}$ & $\begin{array}{l}r, r) \\
r, r \leq \\
r, q r .-\end{array}$ & التمثيل & 1 \\
\hline $\begin{array}{l}., 04 \\
., 8 Y \\
., 0 \vee \wedge\end{array}$ & $\begin{array}{l}r, r \varepsilon \\
r, r r \\
., 00 \wedge\end{array}$ & $\begin{array}{l}\cdot, 04 \\
\cdot, r, \\
\cdot, \ldots\end{array}$ & $\begin{array}{c}r, r \leq \\
r, r q \\
q, r \leq 0-\end{array}$ & $\begin{array}{l}., 07 \\
., 70 \\
., 0 \leq .\end{array}$ & $\begin{array}{l}r, r \leq \\
r, \varepsilon \leq \\
r, . r q-\end{array}$ & $\begin{array}{l}\cdot, 07 \\
\cdot, \vee \\
\cdot, \cdots\end{array}$ & $\begin{array}{l}r, r \leq \\
r, . \leq \\
Y, Y 19\end{array}$ & $\begin{array}{l}\cdot, 07 \\
\cdot, 71 \\
\cdot, \ldots\end{array}$ & $\begin{array}{l}r, r \leq \\
r, 10 \\
\varepsilon, 11 \leq\end{array}$ & $\begin{array}{l}\cdot, 04 \\
., 01 \\
., \ldots r\end{array}$ & $\begin{array}{r}r, r \varepsilon \\
r, \varepsilon \leqslant \\
r, 1 r q-\end{array}$ & & & الديكور & r \\
\hline $\begin{array}{l}., 01 \\
., \leqslant 4 \\
., \ldots\end{array}$ & $\begin{array}{l}r, \leqslant V \\
r, r r \\
Y, \cdot r \wedge\end{array}$ & $\begin{array}{l}., 01 \\
\cdot, r \\
\cdot, \ldots\end{array}$ & $\begin{array}{c}r, \leqslant v \\
r, 79 \\
7, .11-\end{array}$ & $\begin{array}{l}\cdot, 01 \\
., 70 \\
\cdot, \leqslant 14\end{array}$ & $\begin{array}{l}r, \leqslant v \\
r, \leqslant \leqslant \\
\cdot, \wedge r r\end{array}$ & $\begin{array}{l}., 01 \\
., v \cdot \\
\cdot, \ldots\end{array}$ & $\begin{array}{l}r, \varepsilon v \\
r, \cdot \varepsilon \\
q, r v \theta\end{array}$ & $\begin{array}{l}., 01 \\
\cdot, 71 \\
\cdot, \ldots\end{array}$ & $\begin{array}{l}r, \leq v \\
r, 10 \\
v, q \leq r\end{array}$ & & & & & الملابس & $r$ \\
\hline $\begin{array}{l}\cdot, \pi \\
\cdot, \leqslant r \\
., \ldots\end{array}$ & $\begin{array}{c}r, 10 \\
r, r r \\
r, \varepsilon .1-\end{array}$ & $\begin{array}{l}\cdot, \boldsymbol{T} \\
\cdot, \mu \\
\cdot, \ldots\end{array}$ & $\begin{array}{c}r, 10 \\
r, 7 q \\
1 r, .7 r-\end{array}$ & $\begin{array}{c}\cdot, 71 \\
\cdot, 70 \\
\cdot, \cdots\end{array}$ & $\begin{array}{c}r, 10 \\
r, \varepsilon \leq \\
0,9.1-\end{array}$ & $\begin{array}{l}\cdot, 71 \\
\cdot, v \cdot \\
\cdot,+1\end{array}$ & $\begin{array}{l}r, 10 \\
r, \cdot \varepsilon \\
r, r \cdot r\end{array}$ & & & & & & & الموسيقى & $\varepsilon$ \\
\hline $\begin{array}{l}\cdot, v . \\
\cdot, \varepsilon r \\
., \ldots\end{array}$ & $\begin{array}{c}r, \cdot \leq \\
r, r r \\
\wedge, \leq \leq q-\end{array}$ & $\begin{array}{l}\cdot, v \cdot \\
\cdot, r \\
\cdot, \cdots\end{array}$ & $\begin{array}{c}r, . \varepsilon \\
r, 79 \\
1 \leq, .49-\end{array}$ & $\begin{array}{l}\cdot, v \cdot \\
\cdot,{ }_{0} \\
\cdot, \cdots\end{array}$ & $\begin{array}{r}r, \cdot \leq \\
r, \leq \leq \\
v, q \leq \wedge-\end{array}$ & & & & & & & & & الإضاعة & 0 \\
\hline $\begin{array}{l}., 40 \\
., \leqslant 4 \\
., \ldots 1\end{array}$ & $\begin{array}{l}r, \varepsilon \varepsilon \\
r, r r \\
r, r, \Sigma\end{array}$ & 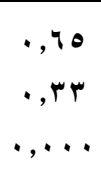 & $\begin{array}{c}r, \varepsilon \leqslant \\
r, 7 q \\
\text { o, } \leqslant \vee .-\end{array}$ & & & & & & & & & & & الماكياج & 7 \\
\hline $\begin{array}{l}\cdot, r r \\
., \leqslant r \\
., \ldots\end{array}$ & $\begin{array}{c}r, 7 q \\
r, \varepsilon r \\
10, \varepsilon \cdot 1\end{array}$ & & & & & & & & & & & & & الماكياج & $v$ \\
\hline
\end{tabular}

* الرمز (ت) يدل قيمة ت لالالة الفروق للمجموعات المرتبطة ، (د) مستوى الدلاةة. 
من نتائج الجدول السابق يتضح وجود فروق ذات دلالة إحــصائية بمقارنـــة منوسطات كل زوج من المهار ات المرتبطة كما كثف عنها اختبار (ت) للمجموعات

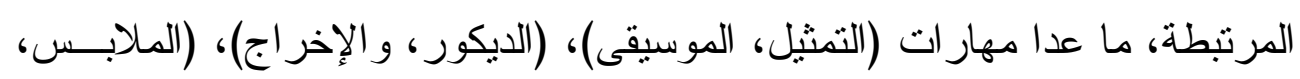

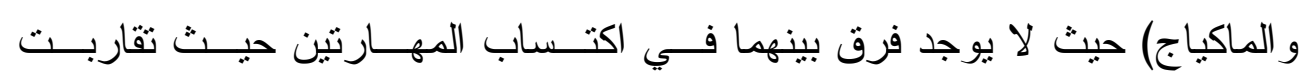
المنوسطات الحسابية لهم ، بينما وجدت فروق دالة إحصائياً بين المهار ات الأخرى فئرئ

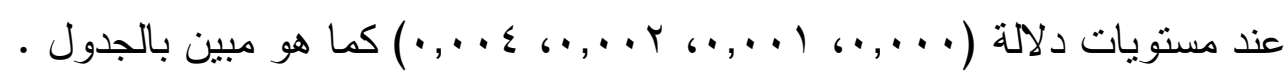

\section{الفرض الثامز :}

"توجد فروق ذات دلالة إحصائية بين متوسطات درجات الطلاب في القياس

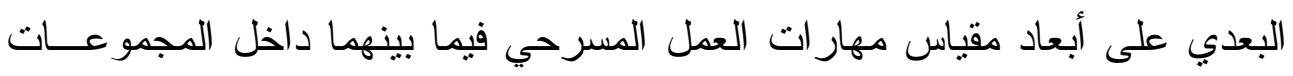
التي يشارك فيها الطالب كل على حده" .

للتحقق من صحة هذا الفرض ولمعرفة مدى اكتساب المهار ات بين الطــلاب

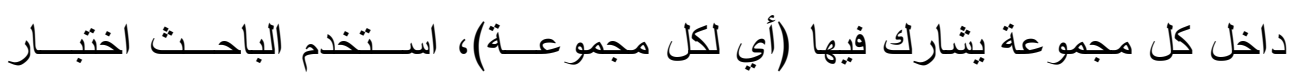

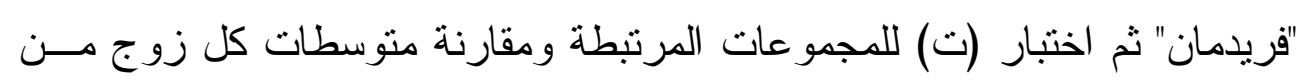
المهار ات وحساب قيمة (ت) ويمكن تتاول ذلك كما يلي: ا- مجموعة التمثيل : ويمكن تتاول نتائجه في الجدول التالي : 
مجلة بحوث التربية النوعية - العدد السابع - بيناير 7 . . مبل

جدول (r) (r)

اختبار "فريدمان" لدلاية الفروق بين متوسطات درجات طلاب مجموعة التمثيل في القياس البعدي على مقياس مهارات العمل المسرحي · مبرد

\begin{tabular}{|c|c|c|c|c|}
\hline متوسط الترتيبات & الانحر اف المعياري & المتوسط & المهارة & b \\
\hline r צ, צ &., 01 & $r, r r$ & التمثيل & 1 \\
\hline$r, q 1$ & •, & $r, \ldots$ & الايكور & $r$ \\
\hline 0,07 & $\cdot, 0$. & $r, \varepsilon \varepsilon$ & الملابس & $r$ \\
\hline$r, r$. & י & $r, \cdot v$ & الموسيقى & $\varepsilon$ \\
\hline$r, 01$ & $\cdot, v$. & $r, q$. & الإضاءة & 0 \\
\hline$\bullet, V \mu$ & $\cdot, \mathrm{VV}$ & $r,\{1$ & الماكياج & 7 \\
\hline$\neg, \wedge r$ & $\cdot, \varepsilon r$ & r, & التعاون & v \\
\hline$\varepsilon, O r$ & $\cdot, \leqslant q$ & $r, Y \wedge$ & الإخر اج & $\wedge$ \\
\hline
\end{tabular}

من نتائج الجدول السابق يتضح وجود فـروق ذات دلالـــة إحــصائية بـين متوسطات درجات طلاب مجموعة التمثيل في القياس البعدي على أبعــاد مقيــاس مهار ات العمل المسرحي، وذلك كما أظهر ها اختبار "فريدمان" حيث بلغـــت قيمــة

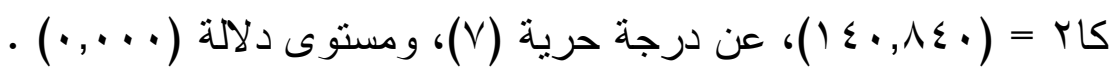

وبمقارنة المتوسطات الحسابية ومتوسط الترتيبات نجد أن أكثر مهــارة تـــ

اكتسابها لدى طلاب مجمو عة التمثيل على الترتيب هي مهارة (التعاون، الملابــس، الماكياج، التمثيل، الإخر اج المسرحي، الموسيقى، الديكور، و الإضـاءة المـسرحية)، أي أن أعلى مهارة ثم اكتسابها لدى مجموعة التمثيل هي مهارة التعاون بمتوســـ حسابي بلغت قيمته (1), ب) و أقل مهارة هي الإضاءة المسرحية بمتوسط حـسابي بلغت قيمته ( • (Y, )، فالتعاون مهارة مهمة لدى فريق التمثيل، وفرق العمل، فـلا 
فعالية التلديبات المسرحية في إكساب طلاب الإعلام التربوي مهارات العدل المسرحي

يمكن تصور وجود أداء تمثيلي دون الحاجة لتكامل هذه المهار ات، أي أن مجهــود الممثل مجهود جماعي أكثر منه مجهوداً فردياً، فالممنل لا بعمل بــدون مـسـاعدة خارجية، مسرحية جيدة التأليف، تضم أثخاصاً صورو ا بعناية يشتركو ا في عمـلـ قوى الحافز، ويحظى بمعاونة منظر جيد التصميم، حسن الإضـاءة بـساعد علـى الإيحاء بالحالة و إظهار روح المسرحية، ومخر ج زكى يفهم المسرحية و الأشخاص، ولديه إمكانيات كافية ليترجم فهمه إلى إخر اج شامل(كارل النزويرث، .91 (: rr). ولمعرفة دلالة الفروق بين متوسط درجات طلاب مجموعــة التمثيــل فــي

اكتساب مهارة التمثيل ومهار ات العمل المسرحي الأخرى، تم إجراء اختبــار (ت)

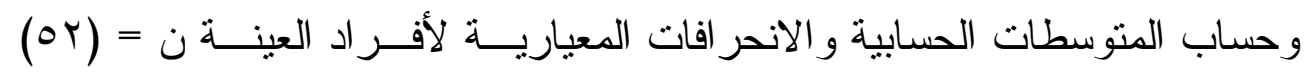
مفردة ويمكن تتاول نتائجه في الجدول التالي : 
جلول (Yr)

اختبار(ت) لدلالة الفروق بين متوسطات درجات الطلاب في القياس البعدي على أبعاد مقياس مهار ات العمل المسرحي

داخل المجموعة التي يشارك فيها الطالب دئ

\begin{tabular}{|c|c|c|c|c|c|c|c|c|c|c|c|c|c|c|c|c|c|c|c|}
\hline \multirow[t]{2}{*}{ د. } & \multirow[t]{2}{*}{$\dot{ن}$} & \multicolumn{2}{|c|}{ الإخراج } & \multicolumn{2}{|c|}{ التعاون } & \multicolumn{2}{|c|}{ الماكياج } & \multicolumn{2}{|c|}{ الإضاءة } & \multicolumn{2}{|c|}{ الموسيقى } & \multicolumn{2}{|c|}{ الملابس } & \multicolumn{2}{|c|}{ الايكور } & \multicolumn{2}{|c|}{ التمثيل } & \multirow{2}{*}{ المهارة } & \multirow[t]{2}{*}{ p } \\
\hline & & $\varepsilon$ & م & $\varepsilon$ & م & $\varepsilon$ & 5 & $\varepsilon$ & 5 & $\varepsilon$ & 5 & $\varepsilon$ & م & $\varepsilon$ & 5 & $\varepsilon$ & 5 & & \\
\hline \multirow[t]{3}{*}{01} & $\Delta r$ &., 01 & $r, r r$ &., 01 & $r, r r$ &., 01 & $r, r r$ &., 01 & $r, r r$ &., 01 & $r, r r$ &., 01 & $r, r r$ &., 01 & $r, r r$ & - & - & التمثيل & 1 \\
\hline & & $\cdot, \leqslant 9$ & $r, Y \wedge$ & .,$\leqslant$ & $r, \uparrow \wedge$ & $\cdot, \mathrm{vV}$ & $r, \varepsilon 1$ & $\cdot, \mathrm{v}$. & r,q. & זr, & $r, \cdot v$ &., 0. & r, \{ & צ & $r, \ldots$ & - & - & & \\
\hline & & 104 & $1,\left\{\begin{array}{lll}0 & 0\end{array}\right.$ & $\cdot, \ldots$ & $V, \Lambda \cdot r-$ & - ,rva & $1, .97-$ & $\cdot, \cdots$ & $0,0 \vee 9$ &,$\ldots$ & $r, \wedge \bullet q$ &.,.,$r$ & $r, Y, r-$ & $\cdot, \cdots$ & 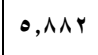 & - & - & ت / د & \\
\hline \multirow[t]{3}{*}{$r v$} & $r \wedge$ & $\cdot, \leqslant T$ & $r, 0 \Lambda$ & . & $r, 01$ & $\cdot, \varepsilon r$ & $r, 0 \Lambda$ & $\cdot, \leqslant \Gamma$ & $r, 0 \Lambda$ & $\cdot, \leqslant \Gamma$ & $\Gamma, 0 \wedge$ & . & $r, 01$ & - & - & $\cdot, \leqslant \Gamma$ & $r, \otimes \Lambda$ & الايكور & $r$ \\
\hline & & . & $r, r$. & ץr, & $r, 79$ &., 70 & r,rr &., 04 & $r, \wedge T$ & $\cdot, \infty 0$ & $r, \wedge q$ &., 7 & $r, Y \leqslant$ & - & - &., 74 & r,१^ & & \\
\hline & & $\cdot, \ldots$ & $0, . \leqslant 9$ & $\cdot, \cdot \wedge v$ & $1, v \circ v-$ & •,,$r \leq$ & ץ & $\cdot, \ldots$ & $9,99$. & $\cdot, \ldots$ & ४,q, & $\cdot, \ldots r$ & $r, \varepsilon+1$ & - & - & $\cdot, \cdots$ & $0,1 \operatorname{li}_{-}$ & ت / د & \\
\hline \multirow[t]{3}{*}{$r V$} & $r \wedge$ & $\cdot, £ \mathrm{~V}$ & rז, & $\cdot, \leqslant \mathrm{V}$ & זע," & $\cdot, \leqslant V$ & זיות & $\cdot, \leqslant \mathrm{V}$ & זד,ץ & $\cdot, \leqslant \vee$ & rיותי & - & - & $\cdot, \varepsilon V$ & rיז,r & $\cdot, \leqslant \vee$ & זיז,ץ & الملابس & $r$ \\
\hline & & ס ט, • & $r, r v$ & $\cdot, r \cdot$ & rז, & $\cdot, \leqslant \wedge$ & r, ז. & $\cdot, \vee_{4}$ & r,qV & $\cdot, \leqslant \wedge$ & $r, . \tau$ & - & - & . & r,rr & •, § & $r, 1$. & & \\
\hline & & $\cdot, \ldots$ & $\varepsilon, ৭ \wedge \wedge$ & $\cdot, 9 \leq$. & $\cdot, \cdot \vee^{\prime}-$ & $\cdot, \mathrm{v} \bullet \wedge$ & $\cdot, \mu l l$. & $\cdot, \ldots$ & ו וO, & $\cdot, \ldots$ & $7, \cdot V \leq$ & - & - & $\cdot, \cdot r$ & - & $\cdot, \ldots$ & $7,90 \leqslant-$ & ت / د & \\
\hline \multirow[t]{3}{*}{11} & 19 & $\cdot, 71$ & rיד, & גו & rז, & $\cdot, \uparrow \wedge$ & זיז,r & - & - & $\cdot, \uparrow \wedge$ & זיד,ץ & 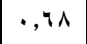 & זיד, & $\cdot, \uparrow \wedge$ & rז, & $\cdot, \uparrow \wedge$ & זיד, & الإضاءة & $\varepsilon$ \\
\hline & & $\cdot, \leqslant r$ & $r, \varepsilon r$ & $\cdot, Y^{\prime}$ & r,TV &., 04 & $r, 19$ & - & - & $\cdot, 79$ & r,IV & . & $r, 09$ & דצץ, & $r, \Delta q$ & • & r, & & \\
\hline & & צ & $1,9 \vee r$ & $\cdot, \mathrm{V} 0$. & - &.,$+1 \leqslant$ & $r, v_{1}$. & - & - &.,$\ldots 7$ & $r,|r|-$ & -, $\vee$ १ & - & $\cdot, \vee \vee \vee 0$ & $\cdot, r q \cdot-$ & $\cdots, \ldots q$ & r,q.7- & ت د د & \\
\hline \multirow[t]{3}{*}{10} & 17 & $\cdot, 11$ & $r, q \leq$ & $\cdot, 11$ & $r, q \leq$ & $\cdot, 11$ & T,q & $\cdot, 11$ & $r, q \leq$ & - & - & $\cdot, 11$ & r,q & $\cdot, 11$ & $r, q \varepsilon$ & $\cdot, 11$ & r, १ะ & الموسيقى & 0 \\
\hline & & דצ & r,or & ד & $r, v r$ & זיום & $r, r q$ & .,Or & $r, 1$. & - & - & • & זיז,r & , Or & $r,\{1$ & $\cdot, r$. & $r, \leqslant r$ & & \\
\hline & & $\cdot, \ldots$ & $Y, \cdot Y 1$ & $\cdot, \ldots$ & $r, r, \tau$ &,$\ldots 1$ & $r, 990$ & $\cdot, \ldots$ & $\checkmark, I \vee r$ & - & - & $\cdot, \cdots v$ & $r, 1,1-$ & $\cdot, \ldots 1$ & $\varepsilon, .90-$ & $\cdot, \ldots$ & Y,OYN- & ت د & \\
\hline \multirow[t]{3}{*}{11} & ir & $\cdot, \cdots$ & $\varepsilon, \cdots$ & . & $\varepsilon, \ldots$ & - & - & $\cdot$ & $\varepsilon, \ldots$ & $\cdot$ & $\varepsilon, \ldots$ & $\cdot, \cdots$ & $\varepsilon, \cdots$ & $\cdot, \cdots$ & $\varepsilon, \cdots$ & $\cdot, \cdots$ & $\varepsilon, \ldots$ & الماكياج & 7 \\
\hline & & זr, & $r,\{1$ & צ & $r, v ч$ & - & - &., 79 & $r, 1 \varepsilon$ & $\cdot, \Delta \mathrm{V}$ & r, & $\cdot, r V$ & ס ז, & $\cdot, \Delta \wedge$ & $r, o r$ & .,Or & $r, 1 \leq$ & & \\
\hline & & $\cdot, \ldots$ & 7,111 & $\cdot, \ldots q$ & $r, 147$ & - & - & $\cdot, \ldots 1$ & \&, I. - &,$\ldots 1$ & $\leqslant, 7 \leqslant,-$ & $\cdot, \ldots 1$ & \&, ०५ q- & $\cdot,+1 \mathrm{~V}$ & Y,A1Y- & $\cdot, \ldots$ & $0, v \leq q-$ & ت / د & \\
\hline \multirow[t]{3}{*}{ ir } & ir & - & - & $\cdot,\{r$ & $r, \leqslant \uparrow$ & $\cdot, \varepsilon r$ & $r, \leqslant 4$ & $\cdot, \varepsilon \uparrow$ & $\Gamma, \varepsilon \uparrow$ & $\cdot, \varepsilon r$ & 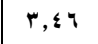 & $\cdot, \leqslant Y$ & $r, \leqslant 4$ & $\cdot, \leqslant Y$ & $r, \leqslant \uparrow$ & $\cdot, \leqslant r$ & $r, \leqslant \uparrow$ & الإخراج & v \\
\hline & & - & - & . & $r, v r$ & r זד, & צ &., 79 & $r, r v$ & .,Or & $r, r \wedge$ &., 04 & $r, £ \wedge$ & $\cdot, \varepsilon V$ & $r, r \wedge$ & $\cdot, 0$ & r,rq & & \\
\hline & & - & - &.,., 11 & $r, q \wedge \vee$ & $\cdot, 1 \cdot 1$ & $1, V r \leq$ &., $.0 r$ & r.171- & ., Y१० & $1, .9 \leq-$ & $\cdot, \vee \vee \vee ५$ & $\cdot, Y q 1$ & - & - & - rro & $1, Y \wedge \cdot-$ & ت / د & \\
\hline
\end{tabular}


فعالية التلريبات المسرحية في إكساب طلاب الإعلام التربوي مهارات العدل المسرحي

من نتائج الجدول السابق بتضح وجود فـروق ذات دلالـــة إحــصائية بــين متوسطات درجات الطلاب مجموعة التمثيل في القياس البعدي على أبعاد مقيــاس مهار ات العمل المسرحي، وذلك كما أوضحه اختبار (ت) في اكتساب مهارة التمثيل ومهار ات العمل المسرحي الأخرى، حيث اكتسب الطلاب مجموعة التمثيل مهــارة التمثيل بالإضافة إلى مهار ات (الديكور، المالابس، الموسيقى، الإضـاءة، التعــاون)،

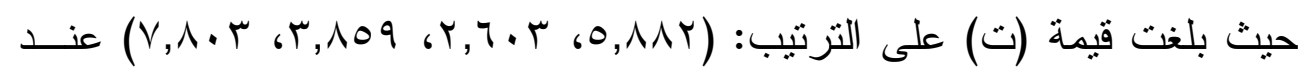

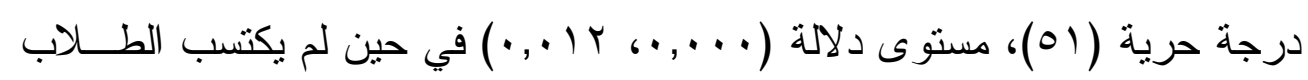
مجموعة التمثيل مهارني (الماكياج و الإكسسوار ، الإخر اج المسرحي)، حيث تقاربت المتوسطات الحسابية للطلاب في هاتين المهارثين • r- مجموعة الديكور : ويمكن تتاول النتائج في الجدول التالي : جدول (rr)

اختبار "فريدمان" لدلالة الفروق بين متوسطات درجات طلاب مجموعة الديكور

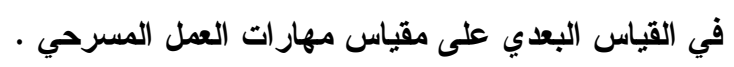

\begin{tabular}{|c|c|c|c|c|}
\hline متوسط الترتيبات & الآحر اف المعياري & المتوسط & المهارة & r \\
\hline צr, & . & $r, q \wedge$ & التمثيل & 1 \\
\hline 7,99 & •, & $\mu, \diamond \wedge$ & الايكور & $r$ \\
\hline$\varepsilon, \wedge r$ & $\cdot, 7$ & $r, Y \leq$ & الملابس & $\mu$ \\
\hline$r, v$. & $\cdot, \infty$ & $r, \wedge q$ & الموسيقى & $\varepsilon$ \\
\hline$r, r v$ &., 07 & $r, \wedge Y$ & الإضاءة & 0 \\
\hline 0,11 & $\cdot, 70$ & r r r & الماكياج & 9 \\
\hline 7,97 & س & $r, 79$ & التعاون & v \\
\hline$\varepsilon, \Delta r$ & $\varepsilon r$ & $r, r$. & الإخر اج & $\wedge$ \\
\hline
\end{tabular}




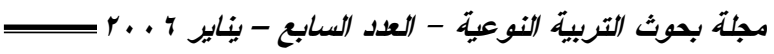

من نتائج الجدول السابق بتضتح وجود فــروق ذات دلالـــة إحــــائية بــين متوسطات درجات الطلاب مجموعة الديكور في القياس البعدي على أبعاد مقيــاس مهار ات العمل المسرحي وذلك كما أظهر ها اختبار فريدمان حيث بلغت قيمة كــاب

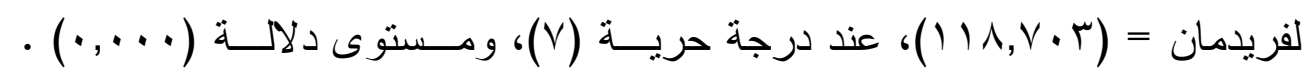
وبمقارنة المتوسطات الحسابية نجد أن أكثر مهارة تــم اكتـسابها لــدى الطــلاب مجموعة الديكور على الترنيب هي مهارة (التعاون، الديكور، الماكياج، المالابـس، الإخر اج المسرحي، التمثيل، الموسيقى، الإضـــاءة المـسرحية) . ووفقـــا لقيمــة المتوسطات الحسابية نجد أن أكثر مهارة تم اكتسابها هي مهارة التعاون بمتوســط حساب بلغت قيمته (9 7, (r)، و أقل مهارة هي مهارة الإضاءة بمتوسط حسابي بلغت • قيمته (r,人

ولمعرفة دلالة الفروق بين منوسط درجات طلاب مجمو عــة الـديكور فــي

اكتساب مهارة الديكور، ومهار ات العمل المسرحي الأخرى تم إجر اء اختبار (ت)، وحساب المتوسطات الحسابية و الانحر افات المعياريــة لأفــر اد العينــة ن = (rی) مفردة كما هو مبين بالجدول (Yr) .

ومن نتائج هذا الجدول يتضح وجود فـروق ذات دلالكـة إحــصائية بـين متوسطات درجات الطلاب مجموعة الديكور، في اكتساب مهارة الديكور ومهار ات العمل المسرحي الأخر ولصالح طلاب مجموعة الديكور في مهــار ات (التمثيـلـ، الديكور، الملابس، الموسيقى، الإضناءة، الماكياج، الإخراج المسرحي)، حيث بلغت

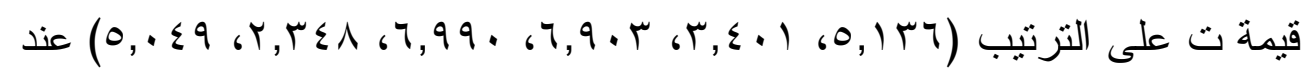

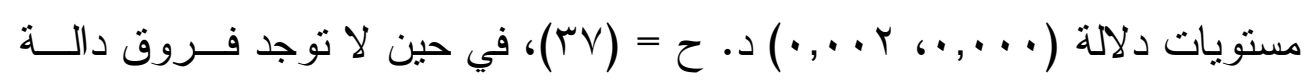
إحصائية بين الطلاب مجموعة الديكور في اكتساب مهارة التعاون، حيث تقاربـــ المتوسطات الحسابية لهم في هذه المهارة، ورذا يعنى أن الطلاب مجموعة الديكور 
فعالية التلريبات المسرحية في إكساب طلاب الإعلام التربوي مهارات الععل المسرحي سل

اكتسبو ا مهار ات التمثيل و الديكور، المـلابـس، الموســيقى، الإضــــاءة، الماكيـــاج، الإخر اج المسرحي، بينما لم يكتسبو ا مهارة التعاون .

ب - مجموعة الملابس : ويمكن تتاول النتائج في الجدول التالي :

جدول (Y)

اختبار "فريدمان" لالالة الفروق بين متوسطات درجات طلاب

مجموعة الملابس في القياس البعدي على مقياس مهارات العمل المسرحي .

\begin{tabular}{|c|c|c|c|c|}
\hline متوسط الترتيبات & الانحر اف المعياري & المتوسط & المهارة & 5 \\
\hline$r, Y)$ & $\cdot, \leqslant \varepsilon$ & $r, 1$. & التمثيل & 1 \\
\hline$\varepsilon, 90$ & צ & $r, r r$ & الديكور & $r$ \\
\hline Y, & $\cdot, \varepsilon V$ & r & الملابس & $r$ \\
\hline$r, 71$ & $\cdot, \leqslant \wedge$ & $r, \cdot r$ & الموسيقى & $\varepsilon$ \\
\hline r, & $\cdot, \vee \vee$ & $r, q V$ & الإضاءة & 0 \\
\hline $7, O r$ & $\cdot, \leqslant \wedge$ & $r, 7$. & 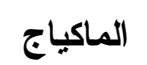 & 7 \\
\hline$\bullet, V$. & $\cdot, \mu$ & r r r r & التعاون & v \\
\hline$\varepsilon, r \bullet$ & • , & $r, r v$ & الإخر اج & $\wedge$ \\
\hline
\end{tabular}

من نتائج الجدول السابق يتضح وجود فـروق ذات دلالـــة إحــصائية بـين متوسطات درجات الطلاب مجموعة المابلس في القياس البعدي على أبعاد مقيــاس مهار ات العمل المسرحي، وذلك كما كثف عنه اختبار "فريدمان"، حيث بلغت قيمة

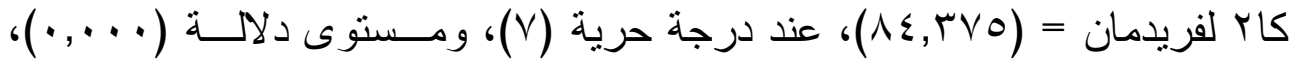
وبمقارنة المتوسطات الحسابية نجد أن أكثر مهارة تم اكتسابها لدى طلاب مجموعة المهلابس على الترنتب هي مهارتي المـلابس و التعاون حيث جاءت فــي الترتيــب الأول يليها مهار ات (الماكياج والإكسسوار، الديكور، الإخراج المسرحي، التمثيل، 


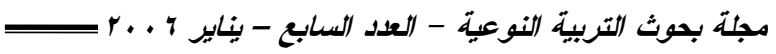

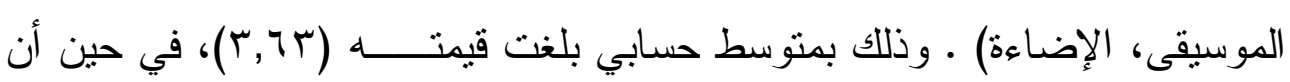

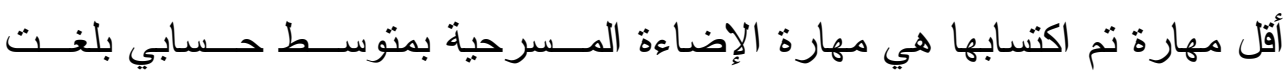
ق قيمته (r,qV)

ولمعرفة دلالة الفروق بين متوسط درجات طلاب مجموعة الملابـس فـي

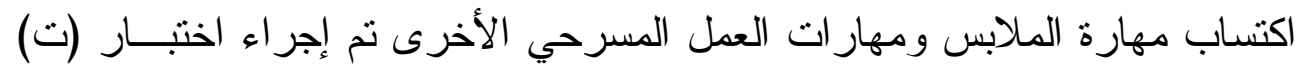

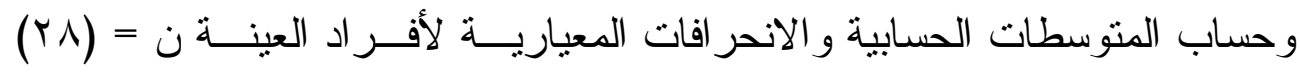

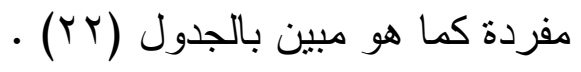

وون نتائج هذا الجدول يتضح وجود فــروق ذات دلالــة إحــصائية بــين

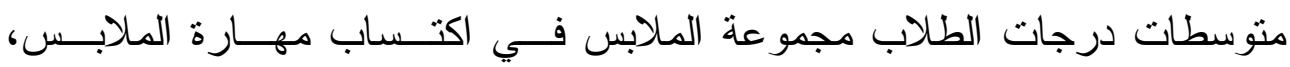
ومهار ات العمل المسرحي الأخرى ولصالح الطلاب مجموعة الملابس في مهار ات

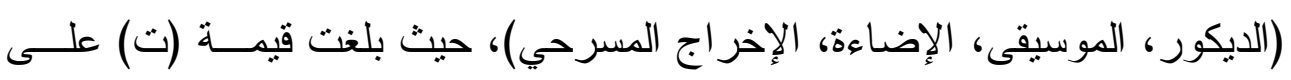

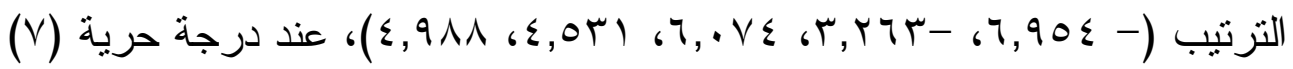

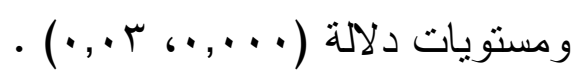

وهذا يعنى أن الطلاب مجموعة الملابس اكتسبو ا مهارة الملابس بالإضــافة

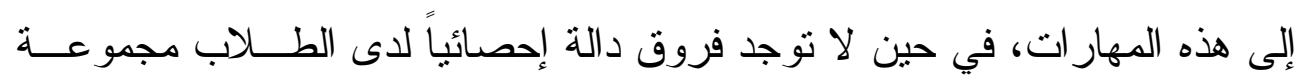
الملابس في اكتساب مهارتي (الماكياج، التعاون) حيث تقاربت المتوسطات الحسابية للطلاب في هاتين المهارتين • ع - مجموعة الإضاءة : ويمكن تتاول النتائج في الجدول التالي : 
فعالية التلريبات المسرحية في إكساب طلاب الإعلام التربوي مهارات العمل المسرحي لـ

$$
\text { جدول (ro) }
$$

اختبار "فريدمان" لالالة الفروق بين متوسطات درجات لطلاب مجموعة الإضاءة

في القياس البعدي على مقياس مهارات العمل المسرحي •

\begin{tabular}{|c|c|c|c|c|}
\hline متوسط الترتيبات & الاتحر اف المعياري & المتوسط & 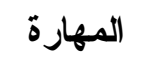 & r \\
\hline$r, \varepsilon 0$ & צ & $r, r \leq$ & التمثيل & 1 \\
\hline $0, r$ T & דצ, & $r, 0 q$ & الايكور & $r$ \\
\hline $0,0 \wedge$ & $\cdot, \leqslant 0$ & $r, 09$ & الملابس & $r$ \\
\hline$r, \wedge r$ &., 79 & $r, i v$ & الموسبقى & $\varepsilon$ \\
\hline 7,17 & $\cdot, 7 \wedge$ & r, & الإضاءة & 0 \\
\hline r, $9 \vee$ & $\cdot, 07$ & $r, 19$ & 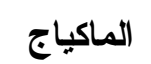 & 9 \\
\hline ט, 0, & דצ & $r, 7 V$ & التعاون & v \\
\hline$\varepsilon, 17$ & $\cdot, \varepsilon r$ & $r, \varepsilon r$ & الإخراج & $\Lambda$ \\
\hline \multicolumn{5}{|c|}{ 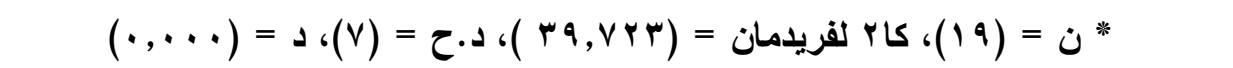 } \\
\hline
\end{tabular}

من نتائج الجدول السابق يتضـح وجود فــروق ذات دلالـــة إحــصائية بــين منوسطات درجات الطلاب مجموعة الإضاءة في القياس البعدي على أبعاد مقياس

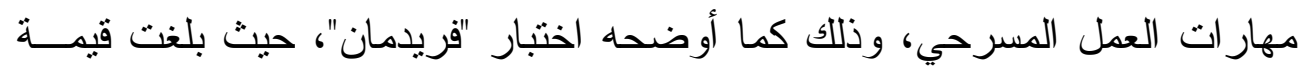

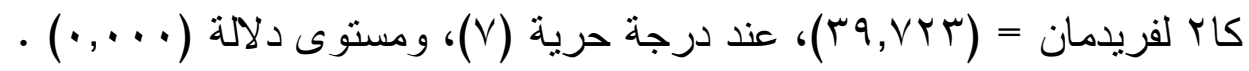
وبمقارنة المتوسطات الحسابية لأفر اد العينة ن = (Y^) مفردة نجد أن أكثــر

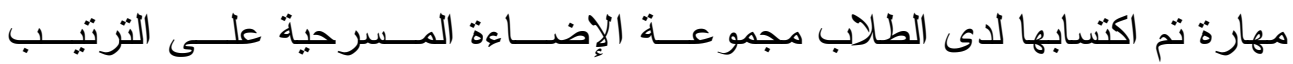

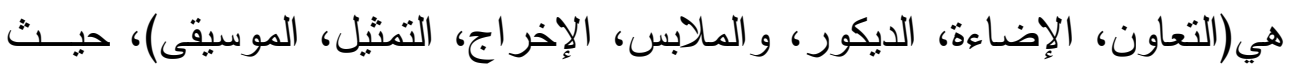

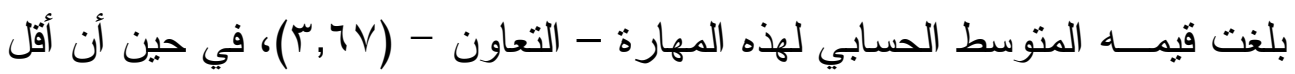
مهارة تم اكتسابها لاى طلاب هذه المجموعة هي مهارة الموسيقى بمتوسط حسابي

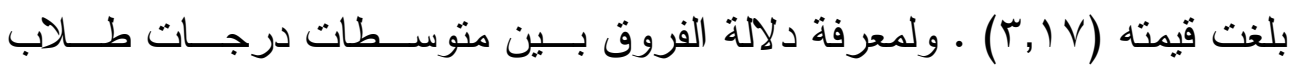


مجلة بحوث التربية النوعية - العدد السابع - يناير r ..r بـ

مجموعة الإضاءة في اكتساب مهارة الإضاءة ومهار ات العمل المسرحي الأخرى،

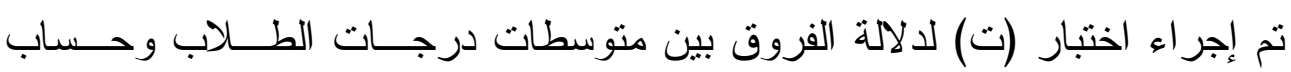

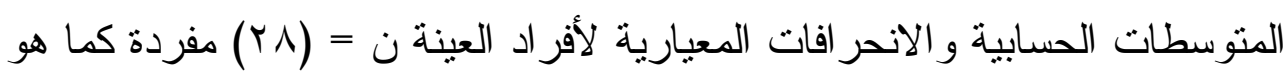

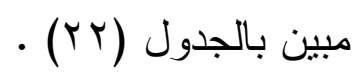

من نتائج هذا الجدول يتضح وجود فروق ذات دلالة إحصائية بين متوسطات

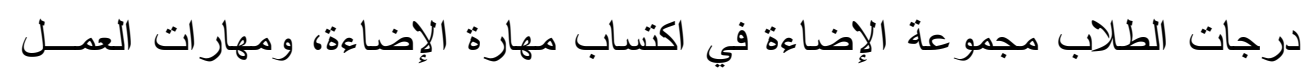

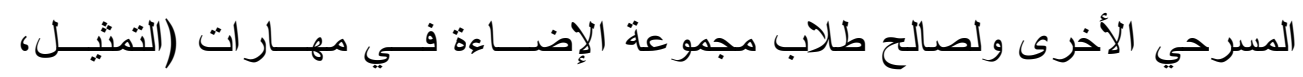

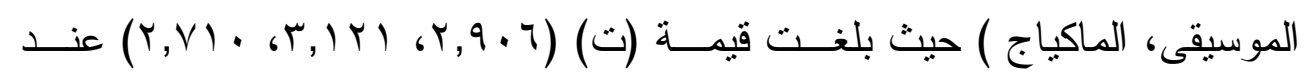

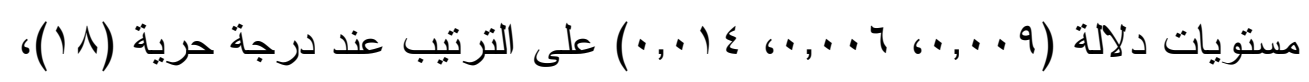

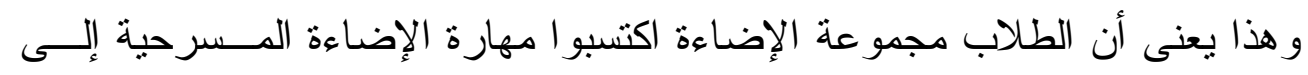

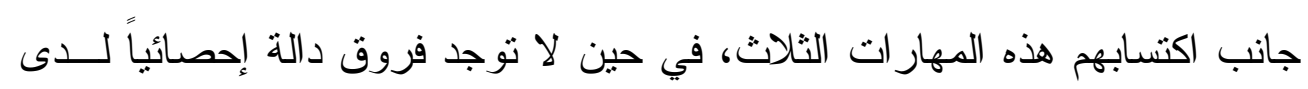

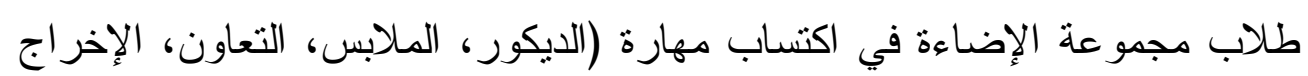

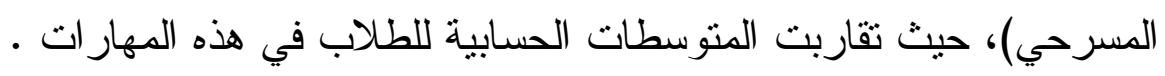
0 - مجمو عة الموسيقى: ويمكن تتاول النتائج في الجدول التالي : 
فعالية التلدريبات المسرحية في إكساب طلاب الإعلام التربوي مهارات العمل المسرحي

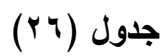

اختبار "فريدمان" لالاةة الفروق بين متوسطات درجات الطلاب مجموعة الموسيقى

في القياس البعدي على مقياس مهارات العمل المسرحي .

\begin{tabular}{|c|c|c|c|c|}
\hline متوسط الترتيبات & الانحراف المعياري & المتوسط & المهارة & م \\
\hline r,o. & • & $r, \varepsilon r$ & التمثيل & 1 \\
\hline$\mu, \wedge \wedge$ & $\cdot, 0 r$ & $r, \varepsilon 1$ & الايكور & $r$ \\
\hline 0,79 & •, & r ז'r & الملابس & $r$ \\
\hline$v, \cdot 9$ & $\cdot, 11$ & $r, q \varepsilon$ & الموسيقى & $\varepsilon$ \\
\hline $1, \vee \wedge$ & •, & $r, 1$. & الإضاءة & 0 \\
\hline$r, q 1$ & • & $r, r q$ & الماكياج & 9 \\
\hline$\bullet, \vee \wedge$ & • & $r, v r$ & التعاون & V \\
\hline \&, & • , & r,or & الإخراج & $\wedge$ \\
\hline \multicolumn{5}{|c|}{ 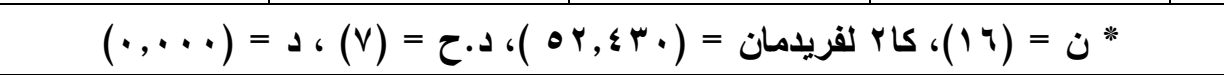 } \\
\hline
\end{tabular}

من نتائج الجدول السابق يتضح وجود فــروق ذات دلالـــة إحــصائية بــين متوسطات درجات الطلاب مجموعة الموسيقى في القياس البعدي على أبعاد مقياس

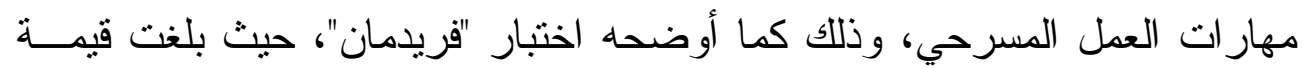

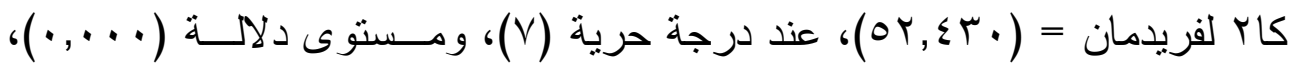

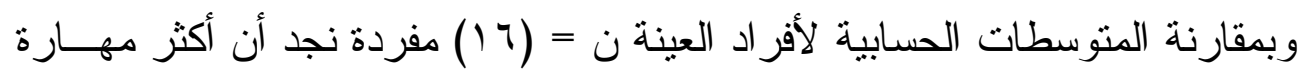
تم اكتسابها لدى الطلاب مجموعة الموسيقى على الترتيب هي (الموسيقى، التعاون، الملابس، الإخر اج، التمثيل، الديكور ، الماكياج، الإضاءة المسرحية ) ، حيث بلغت

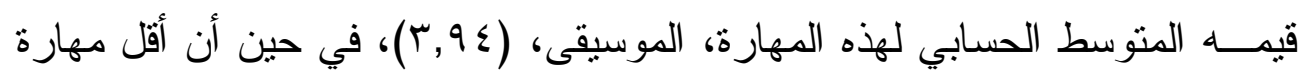
تم اكتسابها لدى طلاب هذه المجموعة هي مهارة الإضـاءة بمتوسط حسابي بلغــــ قيمته ( • (r, ) . ولمعرفة دلالة الفروق بين متوسطات درجات طــلاب مجموعـــة الموسيقى في اكتساب مهارة الموسيقى ومهار ات العمل المسرحي الأخــرى، ثـــ 


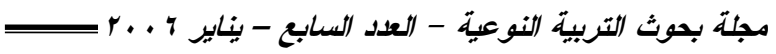

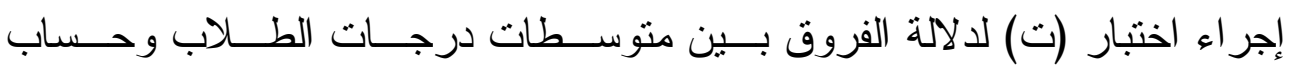

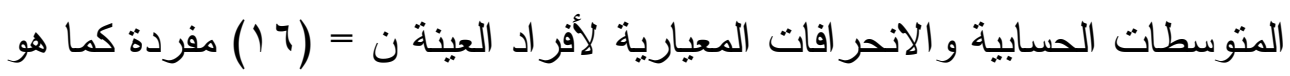

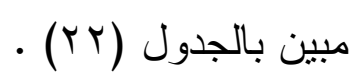

من نتائج هذا الجدول يتضح وجود فروق ذات دلالة إحصائية بين متوسطات

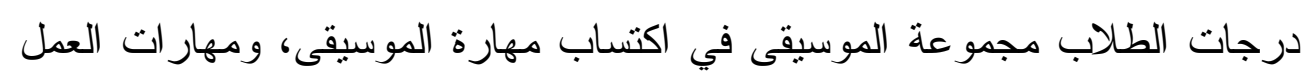

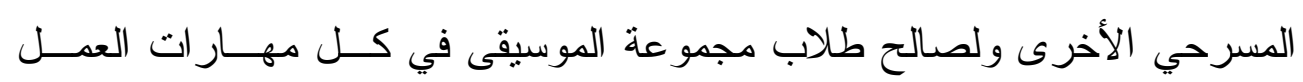

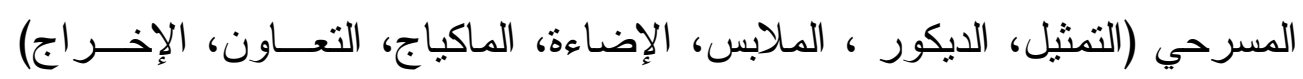

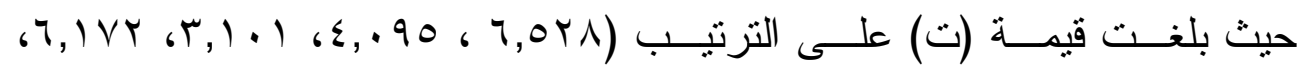

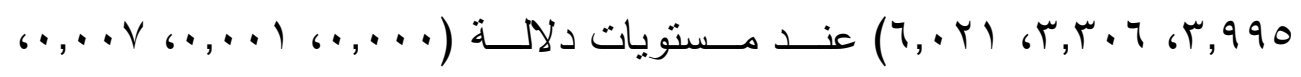

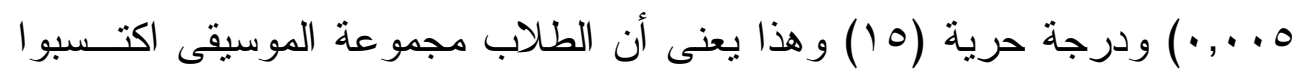

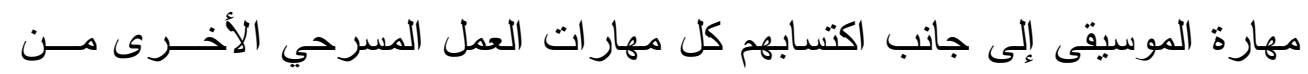

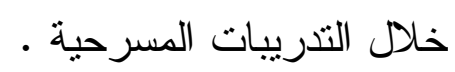
1 - مجموعة الماكياج : ويمكن تتاول النتائج في الجدول النالي : 
فعالية التلريبات المسرحية في إكساب طلاب الإعلام التربوي مهارات العمل المسرحي لـ

جدول (rv)

اختبار "فريدمان" لالالة الفروق بين متوسطات درجات الطلاب مجموعة الماكياج

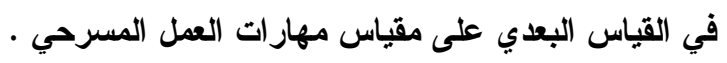

\begin{tabular}{|c|c|c|c|c|}
\hline متوسط الترتيبات & الاححر اف المعياري & المتوسط & المهارة & r n \\
\hline$r, \otimes \leq$ &.,$O r$ & $r, 1 \leq$ & الت التمثيل & 1 \\
\hline$\varepsilon, \vee \bullet$ & $\cdot, \diamond \wedge$ & r,or & الايكور & $r$ \\
\hline$\bullet, \ldots$ & $\cdot, r v$ & r, & الملابس & $r$ \\
\hline$r, \ldots$ & $\cdot, \circ V$ & $r, r \varepsilon$ & الموسيقى & $\varepsilon$ \\
\hline$r, \wedge \wedge$ &., 79 & $r, 1 \leq$ & الإضاءة & ○ \\
\hline V r &,,$\ldots$ & $\varepsilon, \ldots$ & الماكياج & 9 \\
\hline$q, 1 \%$ & • & $r, v q$ & التعاون & $v$ \\
\hline$\varepsilon, \wedge$ & 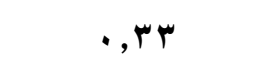 & $r,\{1$ & الإخراج & $\wedge$ \\
\hline \multicolumn{5}{|c|}{ 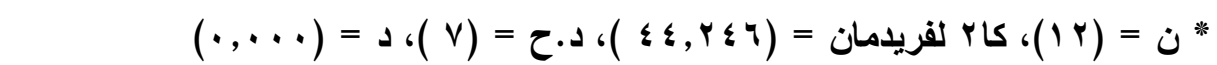 } \\
\hline
\end{tabular}

من نتائج الجدول السابق يتضح وجود فــروق ذات دلالـــة إحــصائية بــين منوسطات درجات طلاب مجموعة الماكياج في القياس البعدي على أبعاد مقيــاس مهار ات العمل المسرحي، وذللك كما أوضحه اختبار "فريدمان"، حيث بلغت قيمــة فئة

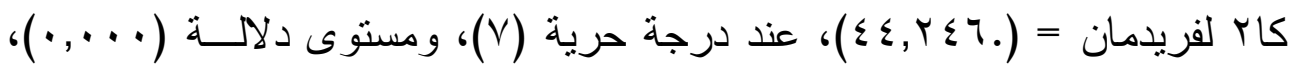
وبمقارنة المتوسطات الحسابية لأفر اد العينة ن = r ا مفردة نجد أن أكثر مهارة تم اكتسابها لدى الطلاب مجموعة الماكياج على الترتيب هي (الماكيــاج، التعـاون،

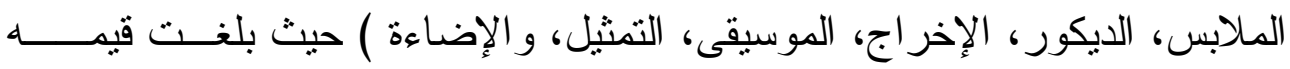

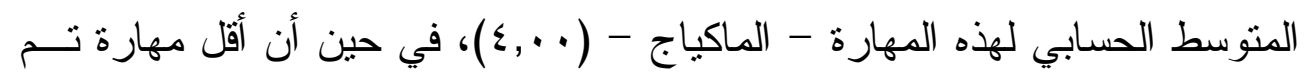
اكتسابها لدى طلاب هذه المجموعة هي مهارة التمثيل و الإضاءة بمتوسط حسـابي

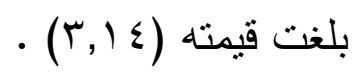


مجلة بحوث التربية النوعية - العدد السابع - بياير 7 . . - مبح

ولمعرفة دلالة الفروق بين متوسطات درجات طلاب مجمو عة الماكياج فـي

اكتساب مهارة الماكياج ومهار ات العمل المسرحي الأخرى، تم إجر اء اختبار (ت) لدلالة الفروق بين متوسطات درجات الطــاتب وحــساب المتوســـات الحــسابية و الانحر افات المعيارية لأفر اد العينة ن = (Y I (Y) مفردة كما هو مبين بالجدول (Y)

من نتائج هذا الجدول يتضح وجود فروق ذات دلالة إحصائية بين متوسطات درجات طلاب مجمو عة الماكياج و الإكسـسو ار فــي اكتـساب مهـــارة المـاكيــاج و الإكسسوار، ومهار ات العمل المسرحي الأخرى حيث اكتسب طــلاب مجموعـــة الماكياج مهارة الماكياج بالإضـافة إلى كل مهار ات العدـلـ المـسرحي الأخــرى (التمثيل، الديكور، المالبس، الإضـاءة، التعاون، الإخر اج) و بلغت قيمة (ت) علـىى

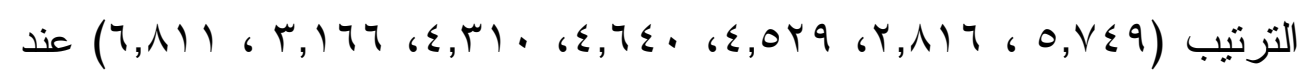

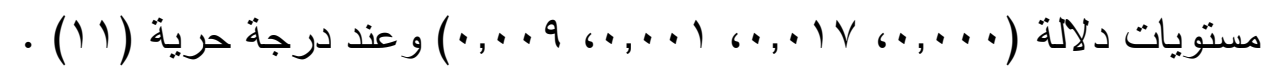
- مجمو عة الإخر اج : ويمكن تتاول النتائج في الجدول التالي :

جدول (Y^)

اختبار "فريدمان" لالالة الفروق بين متوسطات درجات طلاب مجموعة الإخراج

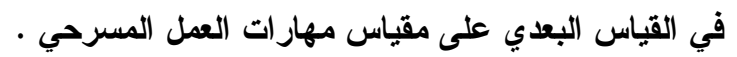

\begin{tabular}{|c|c|c|c|c|}
\hline متوسط الترتيبات & الآحر اف المعياري & المتوسط & المهارة & م \\
\hline r,97 & $\bullet, \infty$ & $r, r q$ & التمثيل & 1 \\
\hline$\Gamma, \diamond \wedge$ & $\cdot, \leqslant V$ & r,r & الديكور & r \\
\hline $0, \ldots$ &., 07 & $\Gamma, \varepsilon \wedge$ & الملابس & $r$ \\
\hline r, ^o & $\cdot, \Delta r$ & r & الموسيقى & $\varepsilon$ \\
\hline$r, r v$ & $\cdot, 79$ & $r, r V$ & الإضاءة & 0 \\
\hline $0,9 r$ & • , & & الماكياج & 9 \\
\hline $7, \cdot \varepsilon$ & $\cdot, r \leq$ & $r, V r$ & التعاون & $v$ \\
\hline$\varepsilon, \mu \wedge$ & $\cdot, \leqslant Y$ & $r, \leqslant 7$ & الإخراج & $\Lambda$ \\
\hline
\end{tabular}


فعالية التلدريبات المسرحية في إكساب طلاب الإعلام التربوي مهارات العمل المسرحي

من نتائج الجدول السابق يتضـح وجود فــروق ذات دلالـــة إحــصائية بــين متوسطات درجات طلاب مجموعة الإخر اج في القياس البعدي على أبعاد مقيــاس

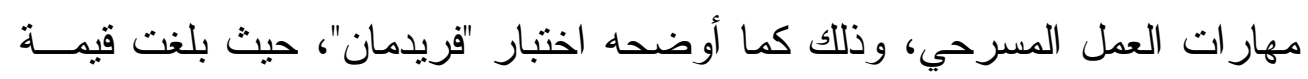

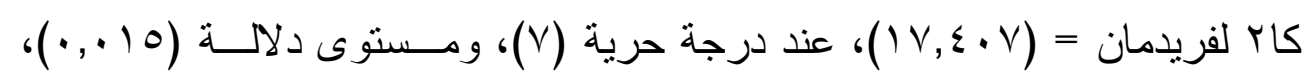

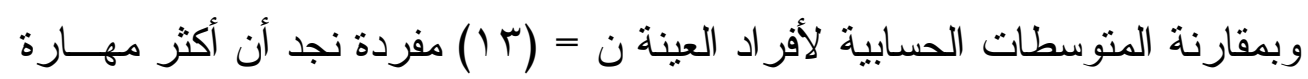

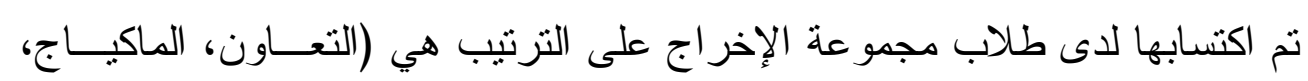

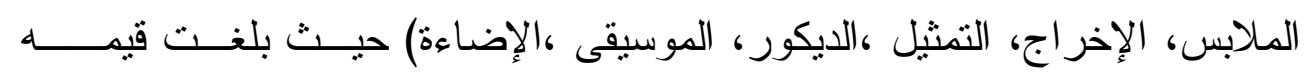

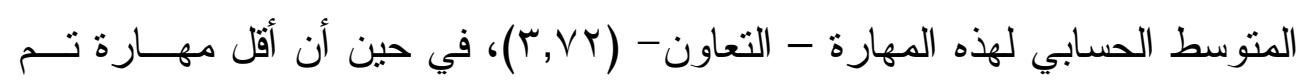

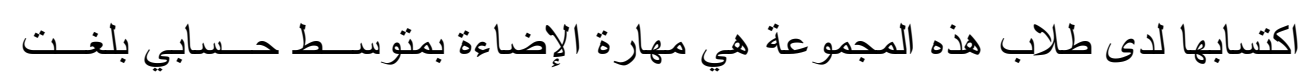
قيمته (r, (rV) (

ولمعرفة دلالة الفروق بين منوسطات درجات طلاب مجموعة الإخر اج فـي

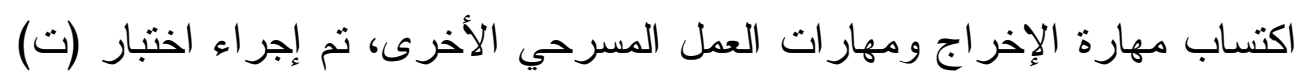
لدلالة الفروق بين متوسطات درجات الطــلاب وحسـساب المتوســـات الحسـسابية و الانحر افات المعيارية لأفر اد العينة ن= (T I ) مفردة كما هو مبين بالجدول (Y (Y). من نتائج هذا الجدول يتضح وجود فروق ذات دلالة إحصائية بين متوسطات

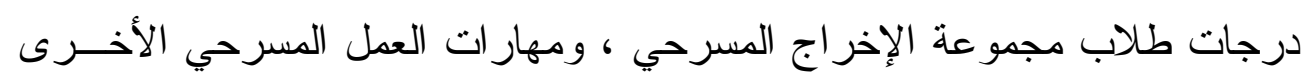

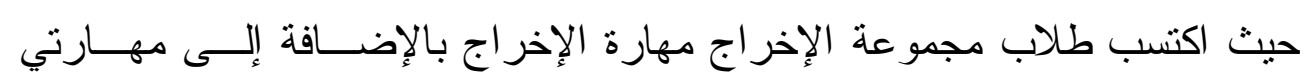

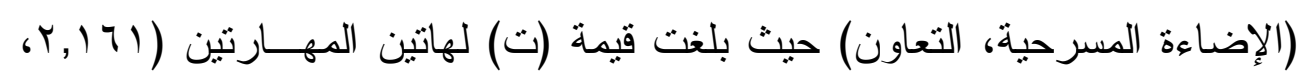

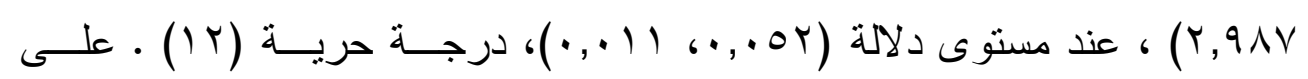

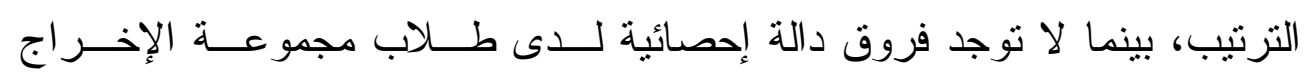
المسرحي في اكتساب مهار ات (التمثني، الديكور، المابس، الموســيقى، الماكيــاج و الإكسسو ار)، حيث تقاربت المتوسطات الحسابية في هذه المهار ات . 


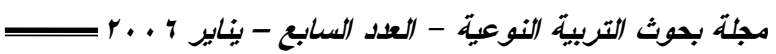

ومما سبق ووفقاً لهذه الفرض يتضح ما يلي :

- الطلاب مجمو عة التمثثيل اكتسبو ا مهارة التمثيل بالإضافة إلى (0) مهــار ات هي (الديكور، الملابس، الإضـاءة، التعــاون) ماعــــا مهــارتي (الماكيــاج،

$$
\text { الإخر اج المسرحي) }
$$

- الطلاب مجموعة الديكور اكتسبو ا مهارة الديكور و(V) مهار ات أخرى هــي (التمثيل، الديكور، المالابس، الموســيقى، الإضــــاءة، الماكيــاج، الإخــر اج

$$
\text { • المسرحي) ما عدا مهارة التعاون }
$$

- الطلاب مجمو عة الملابس اكتسبو ا مهارة الملابس و(ع) مهار ات أخرى هي (الديكور، الموسيقى، الإضـاءة، الإخر اج المـسرحي) . مـــا عــــا مهــارتي

(الماكياج، التعاون) (1)

- الطلاب مجموعة الإضـاءة اكتسبو ا مهارة الإضـاءة و(ب) ومهار ات أخـرى هي (التمثيل، الموسيقى، الماكياج) ماعـــدا مهــار ات (الــديكور، الملابـس،

$$
\text { • التعاون، الإخر اج المسرحي) }
$$

- الطلاب مجمو عة الموسيقى، و الطلاب مجموعة الماكياج اكتسبو ا كل مهار ات

العمل المسرحي الثمانية .

- الطلاب مجموعة الإخر اج اكتسبو ا مهارتي الإخر اج المسرحي و التعاون . وهذا يعنى تحقق الفرض الثامن حيث أدت التدريبات المسرحية إلى اكتساب

الطلاب مهار ات العمل المسرحي وفقاً للمجموعة التي يشارك فيها الطالب .

\section{الفرض القاسع :}

لا يختلف الملاحظين في تقييمهم لمدى اكتساب الطــلاب لمهــار ات العمـلـل

$$
\text { المسرحي على بطاقة ملاحظة مهار ات العمل المسرحي . }
$$

للتحقق من صحة هذا الفرض و الذي يبحث في درجة اختلاف الماحظين في 
فعالية التلريبات المسرحية في إكساب طلاب الإعلام التربوي مهارات العمل المسرحي بـ

تقييم الطلاب لمهار ات العمل المسرحي كما تقيسه بطاقة ملاحظة مهار ات العمـلـل

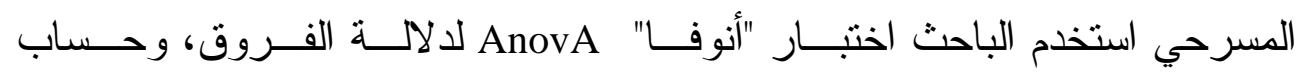

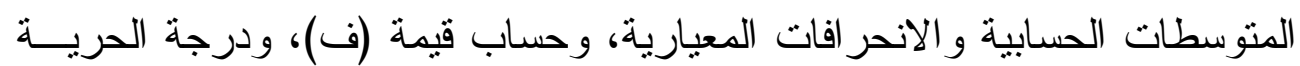

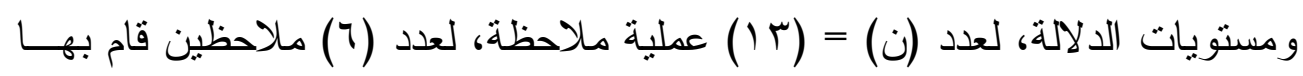
الباحث مع (0) ملاحظين آخرين، لـ (0) عروض مسرحية قدمها طلاب الإعلام التربوي بنوعية المنصورة وفرعيها بميت غمر ومنية النصر وهى موزعه كالتالي البري

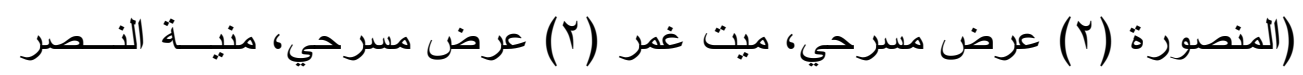
عرض مسرحي و احد) . 
جدول (Yq)

اختبار "أنوفا" لالاحة الفروق بين متوسطات درجات الملاحظين في تقييمهم للطلاب

في مهارات العمل المسرحي على بطاقة الملاحظة .

\begin{tabular}{|c|c|c|c|c|c|c|c|c|c|c|c|c|c|c|c|}
\hline \multirow{3}{*}{ د } & \multirow{3}{*}{ ف } & \multicolumn{12}{|c|}{ الملاحظ } & \multirow{3}{*}{ المهارة } & \multirow{3}{*}{ م } \\
\hline & & \multicolumn{2}{|c|}{ ק } & \multicolumn{2}{|c|}{ مه } & \multicolumn{2}{|c|}{ م ع } & \multicolumn{2}{|c|}{ م } & \multicolumn{2}{|c|}{$r_{p}$} & \multicolumn{2}{|c|}{ ק } & & \\
\hline & & $\varepsilon$ & م & $\varepsilon$ & م & $\varepsilon$ & م & $\varepsilon$ & م & $\varepsilon$ & م & $\varepsilon$ & م & & \\
\hline., $79 \vee$ & $7,1$. & . & $r \cdot, \cdot$ & $\cdot$, & rr,. & $1, \varepsilon$ & $r \cdot, \cdot$ & . & Yr,. & $r, 0$ & 19,0 & $r, \Lambda$ & rr,. & التمثيل & 1 \\
\hline., .91 & $r, \cdot r$. & . & $1 .$, & $\cdot$, & Ir,. & $1, \varepsilon$ & $11,$. & . & $1 ., \cdot$ & $r, l$ & $\Lambda, 0$ & $\cdot, 0$ & $11, \varepsilon$ & الايكور | & $r$ \\
\hline., $.0 r$ & $r, \wedge ৭ \vee$ & . & $1 \leqslant$, & $\cdot, \mathrm{V}$ & $1 \leq, 0$ & $\cdot, \mathrm{V}$ & Ir,o & . & $9,$. & $1, \varepsilon$ & ir,. & $1, r$ & $1 \leqslant, r$ & الملابس | & $r$ \\
\hline., $7 \circ \mathrm{V}$ & \& & . & ir,. & $\varepsilon, r$ & $1 \leq$, & $\varepsilon, q$ & Ir,o & . & 10,0 & $\cdot, \mathrm{V}$ & 10,0 & 1,7 & $17, r$ & الموسيقى & $\varepsilon$ \\
\hline$\cdot, \leqslant \vee V$ & $1, .1$. & . & $\mathrm{v}$, & $\cdot, \mathrm{V}$ & 1,0 & $\cdot, \mathrm{V}$ & $\Lambda, 0$ & . & $9, \cdot$ & . & $1 .,$. & $r, r$ & \& $1 .$, & |لإضاءة & 0 \\
\hline$\cdot, I r v$ & $Y, 0 \leq q$ & . & Ir,. & $1, \varepsilon$ & $11,$. & $r, l$ & $1 ., 0$ & . & $\Lambda, \cdot$ & $\cdot, \mathrm{V}$ & $1 ., 0$ & $\cdot, \varepsilon$ & 11,1 & الماكياج | & 9 \\
\hline$\cdot, \cdot v_{1}$ & $r, \varepsilon, 0$ & . & $9,$. & $\cdot$, & Ir,. & $r, I$ & 9,0 & . & Ir,. & $1, \varepsilon$ & $11,$. & $\cdot, \cdot$ & Ir,. & التعاون | & V \\
\hline \multicolumn{3}{|c|}{ المجموع ن= ب ا ملاحظة } & \multicolumn{2}{|l|}{1} & \multicolumn{2}{|l|}{ r } & \multicolumn{2}{|l|}{ r } & 1 & \multicolumn{2}{|r|}{ r } & \multicolumn{2}{|r|}{0} & \multicolumn{2}{|l|}{$\dot{0}$} \\
\hline
\end{tabular}

" (الرمز (م ا: مج") عدد الملاحظين، (م) المتوسط، (ع) الاحمراف المعياري، (د.ح) درجة الحرية (ء)، مستوى الدلالة، (ن) عدد عمليات الملاحظة . 
من نتائج الجدول السابق يتضح عدم وجود فروق ذات دلالة إحصائية بـين

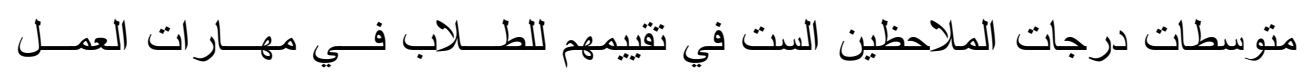
المسرحي في كل أبعاد بطاقة ملاحظة مهار ات العمل المسرحي مـــا عــــا مهــارة

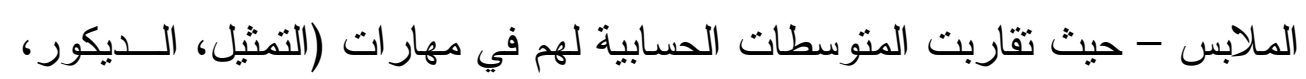

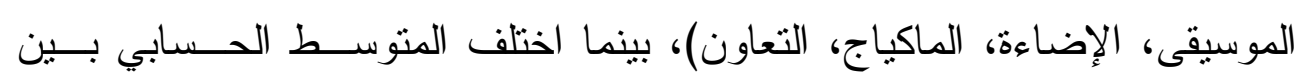

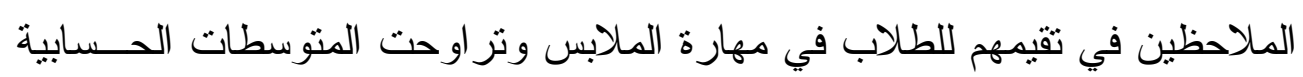

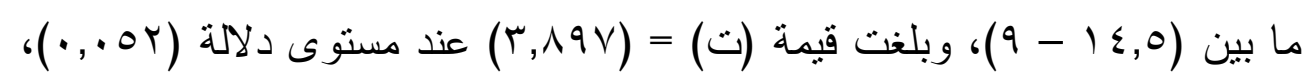

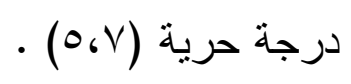

وقد يرجع اختلاف الملاحظين حول تقيمهم للطلاب فـي اكتـساب مهــارة

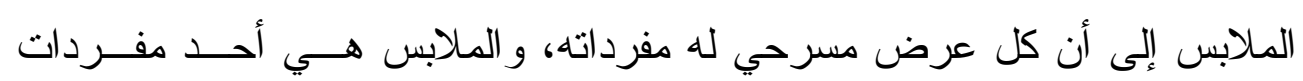

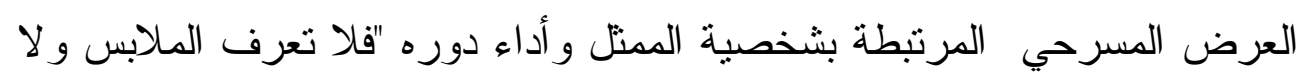

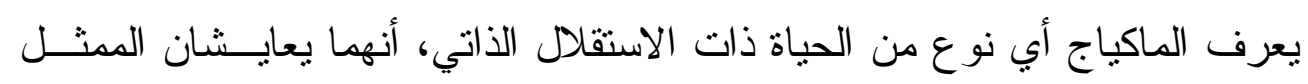

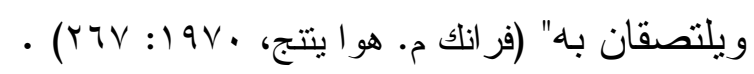

كما أنها تعطى المشاهد طابعاً أولياً عن الثخصية التي يمثلها قبل أن ينطــق

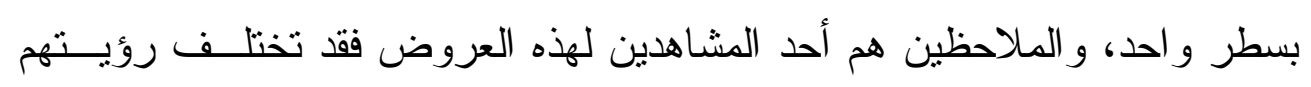

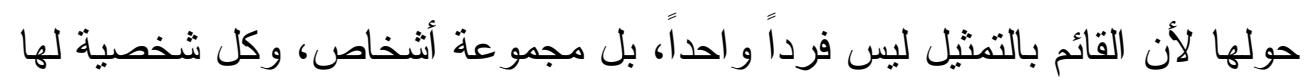

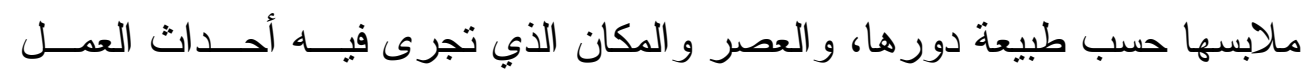

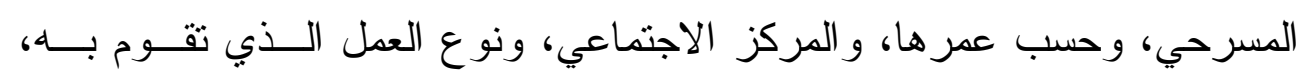
وحالتها النفسية و المز اجية طو ال العمل المسرحي . 


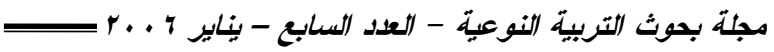

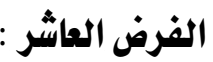

لا يختلف الملاحظين في تقيمهم للطلاب فــي اكتــساب مهــار ات العمـلـل

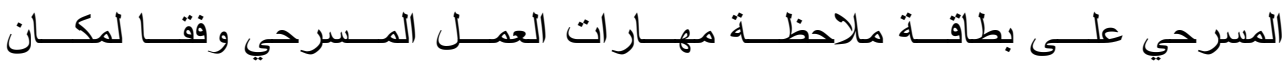
العرض (الكلية)" - مبرية

للتحقق من صحة هذا الفرض استخدم الباحث اختبار " أنوفا"لدلالة الفــروق ،بين متوسطات درجات الملاحظين في تقييم الطلاب في مهار ات العمل المسرحي وفقا لمكان الكلية وحساب المتوسطات الحسابية و الانحر افات المعيارية، وحسساب قيمة (ف)، ودرجة الحرية ومستويات الدلالة، لعدد (ن) = (T I) عملية ملاحظة قام بها الملاحظين الست لــ(0) عروض مسرحية قدمها طلاب الفرقة الر ابعة إعــلام تربوي بكلية التربية النوعية بالمنصورة وفر عيها بميت غمر ومنية النصر .

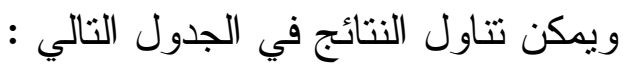

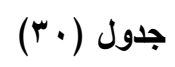

اختبار "أنوفا" لالالة الفروق بين متوسطات درجات الملاحظين في تقيمهم للطلاب على بطاقة ملاحظة مهارات العمل المسرحي وفقاً لمكان العرض (الكلية).

\begin{tabular}{|c|c|c|c|c|c|c|c|c|c|}
\hline \multirow{3}{*}{ د } & \multirow{3}{*}{ ف } & \multicolumn{6}{|c|}{ الكلية } & \multirow{3}{*}{ المهارة } & \multirow{3}{*}{ p } \\
\hline & & \multicolumn{2}{|c|}{ منية النصر } & \multicolumn{2}{|c|}{ ميث غمر } & \multicolumn{2}{|c|}{ المنصورة } & & \\
\hline & & $\varepsilon$ & م & $\varepsilon$ & م & $\varepsilon$ & م & & \\
\hline .,$r \leqslant q$ & $1,1 \vee r$ & $r, \cdot$ & $r \cdot, \cdot$ & $r, \cdot$ & $r, r$ & r, . & $r \cdot, \Lambda$ & التمثيل & 1 \\
\hline$\cdot, \wedge r$ & $r, Y \leq$. & $\cdot, 7$ & $1 \cdot, r$ & $\cdot, \Lambda$ & $11, V$ & 1,9 & 9,1 & الايكور & $r$ \\
\hline., 101 & $Y, Y q \leq$ & $r, 0$ & $11, v$ & $1, r$ & $1 \varepsilon$, & $1, r$ & $I \mu, \Lambda$ & الملابس & $r$ \\
\hline$\cdot, V \backslash \leq$ & $\cdot, r \leqslant \Lambda$ & $r, 0$ & $10, r$ & $Y, \varepsilon$ & $1 \varepsilon, r$ & $1, r$ & 10,0 & الموسيقي & $\varepsilon$ \\
\hline צrו, & $r, \leqslant 01$ & $1, \cdot$ & $\Lambda, \cdot$ & 1,7 & $1 \cdot, r$ & 1,7 & $1 \cdot, \cdot$ & الإضاءة & 0 \\
\hline$\cdot, \wedge \vee \varepsilon$ & צr & $r, r$ & $1 \cdot, v$ & I, & $11,$. & $1, \cdot$ & $11, \pi$ & الماكياج & 7 \\
\hline$\cdot, \wedge ৭ \wedge$ & $\cdot, 1 \cdot 9$ & $1, V$ & 11, & 1,7 & $11, r$ & $1, \cdot$ & 11,0 & التعاون & V \\
\hline \multicolumn{2}{|c|}{ 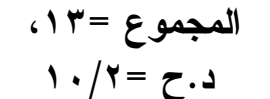 } & \multicolumn{2}{|c|}{$r$} & \multicolumn{2}{|c|}{7} & \multicolumn{2}{|c|}{$\varepsilon$} & \multicolumn{2}{|l|}{ ن } \\
\hline
\end{tabular}


فعالية التلدييات المسرحية في إكساب طلاب الإعلام التربوي مهارات العمل المسرحي ــ

من نتائج الجدول السابق يتضح عدم وجود فروق ذات دلالة إحصائية بـين متوسطات درجات الملاحظين على بطاقة ملاحظة مهار ات العمل المسرحي فــي

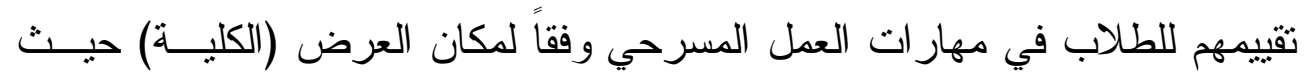
تقاربت المتوسطات الحسابية في تقييم الملاحظين لهذه المهار ات في الكليات النوعية

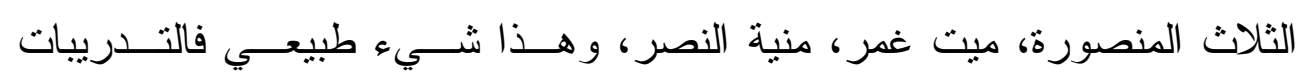
المسرحية في الثناث كليات قام بها مدرب واحد وهو الباحث وذللك بصرف النظر منه

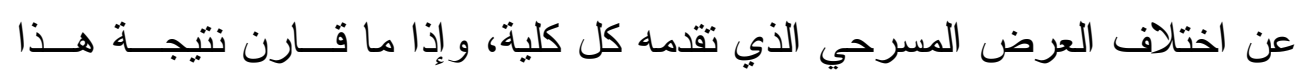

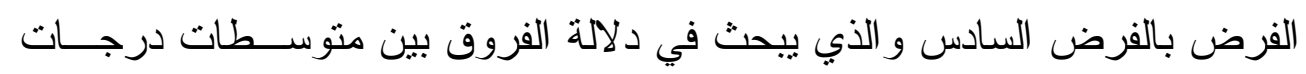

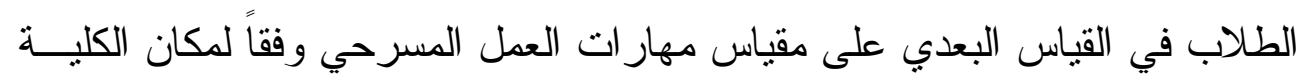

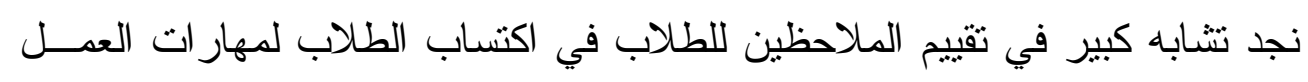
المسرحي وبين عدم وجود فروق بين متوسطات درجات الطلاب ترجـــع لمتغيـر

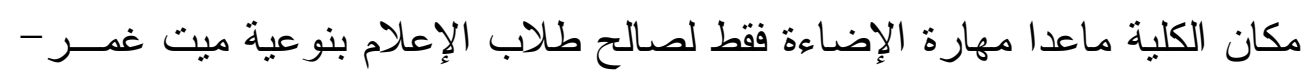
وهذا يدل على صدق أدوات الدراسة ـ وتحقق الفرض العاثر كلياً .

\section{الفرض الحادي عشر :}

"لا يختلف الملاحظين في تقييمهم للطلاب فـي اكتـساب مهــار ات العمـلـل

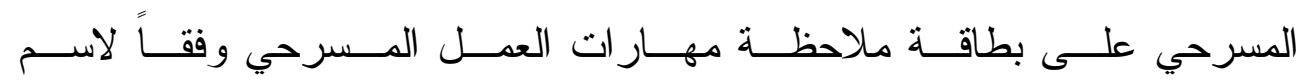

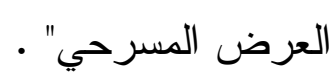

للتحقق من صحة هذا الفرض، استخدم الباحث اختبار "أنوفا" لدلالة الفــروق بين متوسطات درجات الملاحظين في تقييم الطلاب في مهار ات العمل المسسرحي وفقاً لاختلاف مسمى العرض المسرحي، وتــم حـسـاب المتوســـات الحسـابية

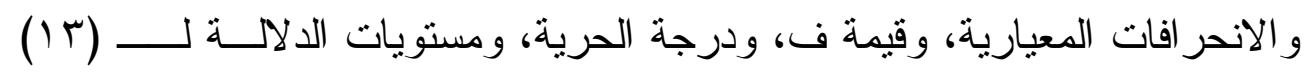
عملية ملاحظة قام بها (؟) ملاحظين لـ (0)عروض مسرحية قدمها طلاب الفرقة وديه 
مجلة بحوث التربية النوعية - العدد السابع - بياير 7 . . - مبح

الر ابعة إعلام تزبوي بكلية التربية النوعية بالمنصورة، وميت غمر، ومنية النصر

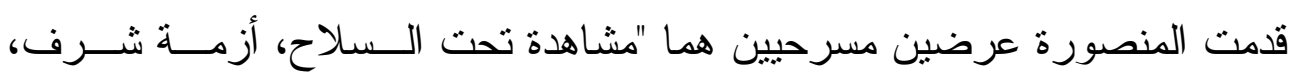
وقدمت ميت غمر عرضين مسرحيين هما" نوبة شجاعة، وصياح الديوك ومسـوت الملولك"، وقدمت منية النصر عرض مسرحي و احد وهو "نوبة شــــاعة" ويمكـن تتاول ذلك في الجدول التالي :

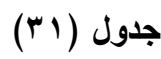

اختبار أنوفا لدلاحة الفروق بين متوسطات درجات الملاحظين في تقيمهم للطلاب

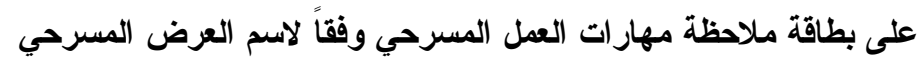

\begin{tabular}{|c|c|c|c|c|c|c|c|c|c|c|c|c|c|}
\hline \multirow{4}{*}{ د } & \multirow{4}{*}{ ف } & \multicolumn{10}{|c|}{ اسم العرض } & \multirow{4}{*}{ | المهارة || } & \multirow{4}{*}{ r } \\
\hline & & \multirow{2}{*}{\multicolumn{2}{|c|}{ نوية شنية النصر }} & \multicolumn{4}{|c|}{ ميث غمر } & \multicolumn{4}{|c|}{ المنصورة } & & \\
\hline & & & & \multicolumn{2}{|c|}{ نوبة شجاعة } & \multicolumn{2}{|c|}{ صياح الديوك } & \multicolumn{2}{|c|}{ أزمة شرف } & \multicolumn{2}{|c|}{ مشاهدة تحت } & & \\
\hline & & $\varepsilon$ & 5 & $\varepsilon$ & 5 & $\varepsilon$ & 5 & $\varepsilon$ & 5 & $\varepsilon$ & 5 & & \\
\hline$\cdot, \wedge r$ & $r, \cdot Y Y$ & $r, \cdot$ & $r \cdot, \cdot$ & 1,0 & rr, & $r, Y$ & rr, & $1, \varepsilon$ & $r r,$. & Y,l & $1 \wedge, 0$ & التمثيل & 1 \\
\hline$\cdot|>|$ & $r, 1 \cdot \Lambda$ & $\cdot, 7$ & $1 \cdot, r$ & $1, r$ & $11, r$ & $\cdot, \cdot$ & Ir,. & $\cdot, \mathrm{V}$ & $1 ., 0$ & $r, \Lambda$ & $9, \cdot$ & الديكور & $r$ \\
\hline$\cdot, r \wedge 1$ & $1, r \cdot 1$ & $r, 0$ & $11, \mathrm{v}$ & 1, & $1 \leqslant$, & $1, v$ & $1 \leqslant$, & $\cdot, \mathrm{V}$ & $1 \leqslant, 0$ & $1, \varepsilon$ & ir,. & الملابس & $r$ \\
\hline., $.9 \wedge$ & $r, \wedge r$. & $r, 0$ & $10, r$ & $\cdot, 7$ & $17, v$ & $r, 1$ & $11, v$ & $\cdot, \mathrm{V}$ & 17,0 & $\cdot, \mathrm{V}$ & $1 \leqslant, 0$ & الموسيقى & $\varepsilon$ \\
\hline - YYo & $1,09 \mathrm{~V}$ & $1, \cdot$ & $\wedge, \cdot$ & 1,0 & 1.,r & $r, l$ & $1 \cdot, r$ & $1, \varepsilon$ & $11,$. & $1, \varepsilon$ & $9,$. & |لإضاءة | & 0 \\
\hline$\cdot, 0 \cdot v$ & $\cdot, 9 \cdot 1$ & $r, r$ & $1 \cdot, \mathrm{V}$ & $1, \cdot$ & $1,$, & $\cdot, \cdot$ & Ir, & $\cdot, \mathrm{V}$ & 11,0 & $1, \varepsilon$ & $11,$. & |لماكياج | & 7 \\
\hline$\cdot, \wedge \div 0$ & $\cdot, r \cdot \Lambda$ & $1, v$ & $11,$. & $\cdot, 7$ & $11, v$ & $r, r$ & $1 \cdot, v$ & $\cdot, \cdot$ & Ir,. & $1, \cdot$ & 11,0 & التعاون & v \\
\hline \multicolumn{2}{|c|}{ 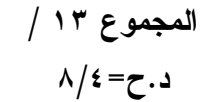 } & \multicolumn{2}{|r|}{$r$} & \multicolumn{2}{|r|}{$r$} & \multicolumn{2}{|r|}{$r$} & \multicolumn{2}{|r|}{$Y$} & \multicolumn{2}{|r|}{$r$} & \multicolumn{2}{|l|}{ ن } \\
\hline
\end{tabular}

من نتائج الجدول السابق يتضح عدم وجود فروق ذات دلالة إحصائية بـين متوسطات درجات الملاحظين على بطاقة مهار ات العمل المسرحي فـي تقــيمهم للطلاب في مهار ات العمل المسرحي وفقاً لاســم العــروض المـسرحية الخمسـس المقدمة، حيث تقاربت المتوسطات الحسابية في تقييم الملاحظين لهذه المهار ات وفقاً 
فعالية التدريبات المسرحية في إكساب طلاب الإعلام التربوي مهارات العمل المسرحي سل

لمسمى العرض المسرحي، وهذا يعنى أن تقييم الملاحظين لاكتساب المهار ات لــــ يتأثز باختلاف العرض، وبهذا يتحقق الفرض الحادي عشر كلياً .

\section{الفرض الثاني عشر :}

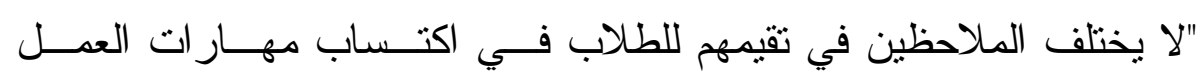

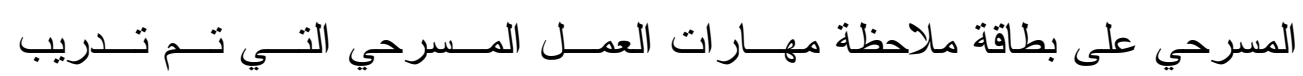

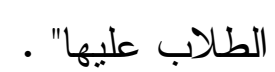

للتحقق من صحة هذا الفرض، استخدم الباحث اختبار "فريدمان" لمعرفة دلالة

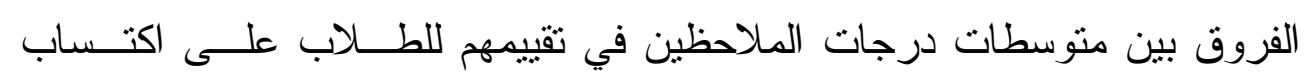

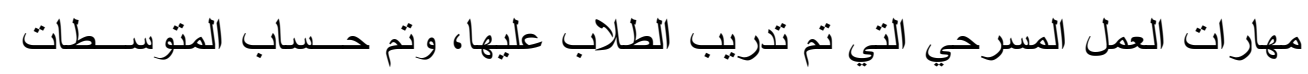

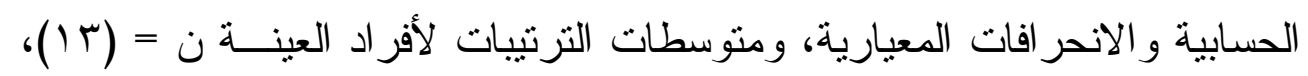

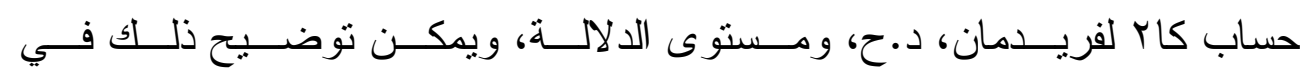

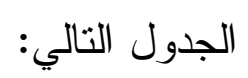

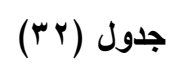

اختبار "فريدمان" لالالة الفروق بين متوسطات درجات الملاحظين

في تقيمهم للطلاب في مهارات العمل المسرحي على بطاقة الملاحظة.

\begin{tabular}{|c|c|c|c|c|}
\hline متوسط الترتيبات & الاححر اف المعياري & المتوسط & المهارة & b \\
\hline$\varepsilon, 1 r$ & $\cdot, r q$ & $r \cdot 74$ & التمثيل & 1 \\
\hline$r, 97$ & צ & P, $7 q$ & الايكور & $r$ \\
\hline$\{, \mu$ & • & Y, ४ & الملابس & $r$ \\
\hline$r, . \wedge$ & 织 & $r, \varepsilon V$ & الموسيقى & $\varepsilon$ \\
\hline$r, 79$ & . & $r, \leqslant r$ & الإضاءة & 0 \\
\hline ( & ـ & r, vo & ماكياج & 9 \\
\hline $0, \leqslant 4$ & $\cdot, r \varepsilon$ & $r, \Lambda 1$ & تعاون & $v$ \\
\hline \multicolumn{5}{|c|}{ 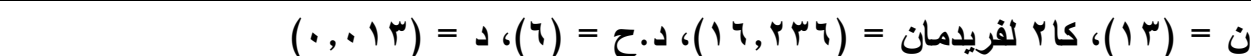 } \\
\hline
\end{tabular}




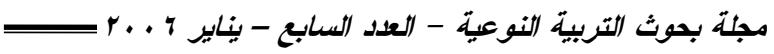

من نتائج الجدول السابق يتضح وجود فـروق ذات دلالـــة إحــصائية بــين متوسطات درجات الملاحظين في تقييمهم للطلاب في اكتـساب مهــار ات العمـلـ

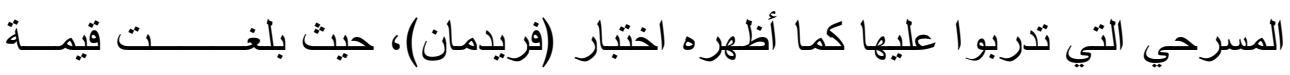

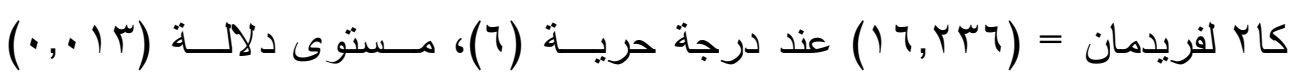
وبمقارنة المنوسطات الحسابية نجد أن أكثر مهارة تم اكتسابها لدى الطلاب ووفقـاً لتقبيم المالحظين هي على التزتيب (التعاون، الماكيــاج و الإكسـسوار، الــديكور ،

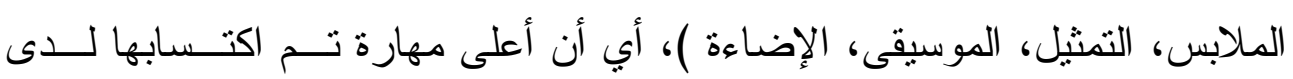
الطلاب هي مهارة التعاون بمتوسط حسابي قيمته (Y,N (Y) مقابل متوسط حسـابي

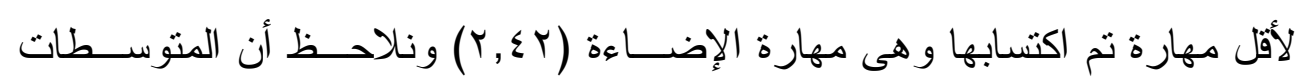

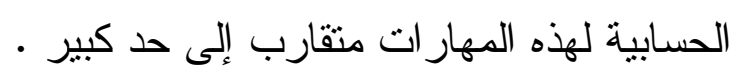

ولمعرفة دلالة الفروق بين منوسطات درجات الملاحظين في تقييمهم للطلاب على مهار ات العمل المسرحي اســتخدم الباحــث اختبــار (ت) لدلالــــة الفـروق للمجموعات المرتبطة، وحساب المتوسطات الحسابية و الانحر افات المعيارية، وقيمة ت، درجة الحرية، ومستويات الدلالة لعدد (T I) عملية ملاحظة كمــا هــو مبـين

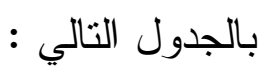




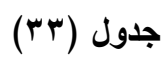

اختبار(ت) لالالة الفروق بين متوسطات درجات الملاحظين في تقييمهم لمهارات العمل المسرحي

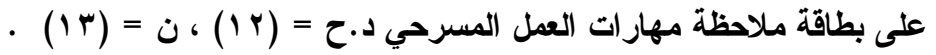

\begin{tabular}{|c|c|c|c|c|c|c|c|c|c|c|c|c|c|}
\hline \multicolumn{2}{|c|}{ التعاون } & \multicolumn{2}{|c|}{ الماكياج } & \multicolumn{2}{|c|}{ الإضاءة } & \multicolumn{2}{|c|}{ الموسيقى } & \multicolumn{2}{|c|}{ الملابس } & \multicolumn{2}{|c|}{ الايكور } & \multirow{2}{*}{ قيمة تات د د المهارة } & \multirow[t]{2}{*}{ s } \\
\hline$\varepsilon$ & 5 & $\varepsilon$ & 5 & $\varepsilon$ & 5 & $\varepsilon$ & 5 & $\varepsilon$ & 5 & $\varepsilon$ & 5 & & \\
\hline$\cdot, r q$ & צוז, & •, Yq & r, & •, rq & צד, & •, rq & Y, 79 & •, זq & Y, TY & $\cdot, r q$ & Y.Y & التمثيل & 1 \\
\hline$\cdot, r \leq$ & $r, \wedge l$ & • & r, Vo & $\cdot, \varepsilon r$ & $r, \varepsilon r$ & $\cdot, \varepsilon r$ & $r, \varepsilon V$ & • & $r, r \wedge$ & דו & $r, 79$ & ت / د & \\
\hline., 1.0 & 1,vor- &., $0 \ldots$ & .,790- &., .11 & r,qA1 &., 179 & سדצ ו ו & $\cdot, \wedge \wedge 1$ &., $104-$ &.,$V R r$ & .,$\Gamma \leqslant 9-$ & & \\
\hline ., & r, & צ ז & r, & . & $r, 7 q$ & צ & r, $7 q$ & ד & $r, 7 q$ & & & الديكور & $r$ \\
\hline$\cdot, r \leq$ & $r, \wedge 1$ & 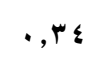 & r, vo & $\cdot, \varepsilon r$ & $r, \leqslant r$ & • & $r, \varepsilon V$ & • & r, & & & ت / د & \\
\hline . &., $9 \times 1-$ & $\cdot, 0 \wedge \leq$ & .,0 Y - & $\cdot, \cdot 4 \wedge$ & $r, \ldots v$ & $\cdot, r \mid r$ & $1, \mu \backslash v$ & $\cdot, \wedge \wedge 0$ & $\cdot, 1 \leq 1$ & & & & \\
\hline • t, & $r, \uparrow \Lambda$ & • t, & $r, \uparrow \wedge$ & • D & r, & • מ, מ & $r, Y \wedge$ & - & - & & & الملابس & $r$ \\
\hline$\cdot, r \leq$ & $r, \wedge !$ & • & r, vo & $\cdot, \leqslant r$ & $r, \varepsilon r$ & $\cdot, \leqslant r$ & $r, \leqslant V$ & - & - & & & ت / د & \\
\hline - rar & $1,1, r-$ & . rar & $\cdot, \wedge \wedge \vee-$ & ד & r,rur &., 191 & איז, & - & - & & & & \\
\hline$\cdot, \leq \Gamma$ & $r, \leqslant V$ & $\cdot, \leqslant r$ & $r, \varepsilon V$ & $\cdot, \leqslant$ & $r, \leqslant V$ & - & - & & & & & |الموسيقى | & $\varepsilon$ \\
\hline$\cdot, r \leq$ & $r, \wedge l$ & $\cdot, r \leq$ & r,vo & $\cdot, \varepsilon r$ & $r, \varepsilon r$ & - & - & & & & & ت & \\
\hline$\ldots$ & $r, T Y \leq-$ & ع & $1, Y \cdot V-$ &.,$\times 19$ & גו & - & - & & & & & & \\
\hline • & $r, \& r$ & • & $r, \& r$ & - & - & & & & & & & الإضاءة & 0 \\
\hline$\cdot, r \leq$ & $r, \wedge 1$ & ع & r, Vo & - & - & & & & & & & د & \\
\hline$\cdot, \ldots r$ & r,ฯAr- & $\cdot, ., 1 \wedge$ & $r, r \cdot V-$ & - & - & & & & & & & & \\
\hline . & r,Yo & - & - & & & & & & & & & الماكياج & 7 \\
\hline$\cdot, r \varepsilon$ & $r, \wedge 1$ & - & - & & & & & & & & & ت د & \\
\hline., 794 & ., ๕. . - & - & - & & & & & & & & & & \\
\hline
\end{tabular}


مجلة بحوث التربية النوعية - العدد السابع - بيناير 7 . . مبل

من نتائج الجدول السابق يتضح وجود فـروق ذات دلالـــة إحــصائية بــين

متوسطات درجات الملاحظين في تقييمهم لمهار ات العمل المسرحي التــي تـدرب علبها الطلاب ويمكن توضيح ذلك كالآتي:

- وجدت فروق بين مهارة التمثيل و الإضـاءة لصالح مهارة التمثيــل ، حيــث

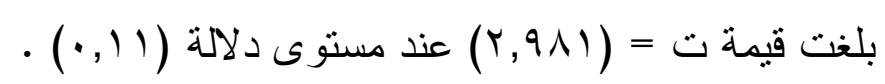

- وجدت فروق بين مهارة الملابس و الإضاءة ولصالح مهارة الملابس ، حيث

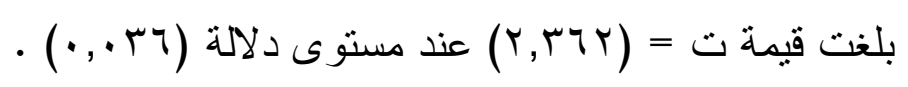

- وجدت فروق بين مهارة الموسيقى و التعاون ولصالح مهارة التعاون ، حيث

$$
\text { بلغت قيمة ت = ( }
$$

- وجدت فروق بين مهارة الإضـاءة و الماكياج، الإضـاءة و التعــاون، ولـصـالح

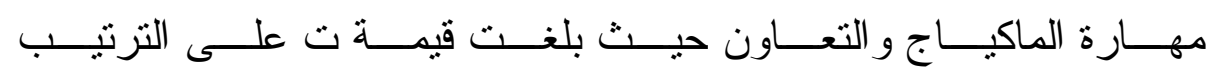

$$
(r, T \wedge r, r, r \cdot V)
$$

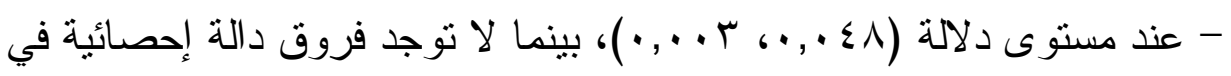
تقييم الماحظين لبعض المهار ات الأخرى التي تدرب عليها الطلاب حيـــث تقاربت المتوسطات الحسابية لهذه المهار ات.

وعن المهار ات الأخرى التي تم اكتشابها أثناء التذريبات المـسرحية ذكـر

الطلاب المهار ات التالبة :

$$
\text { • الصبر و المثابرة . }
$$$$
\text { • - م الالتز ام بالمو اعبد. }
$$

• تحمل المسئولية و إنجاز الأعمال الموكلة إلينا • القيادة و إدارة فريق العمل.

$$
\text { • الهدوء في العمل • }
$$
• اتخاذ القر ار •

$$
\text { • النظام وحب العمل • }
$$$$
\text { • احتر ام العمل الجماعي. }
$$

• الأمل في نجاح العمل المسرحي • • توزيع الأدوار و المسئوليات 
فعالية التلريبات المسرحية في إكساب طلاب الإعلام التربوي مهارات الععل المسرحي سل

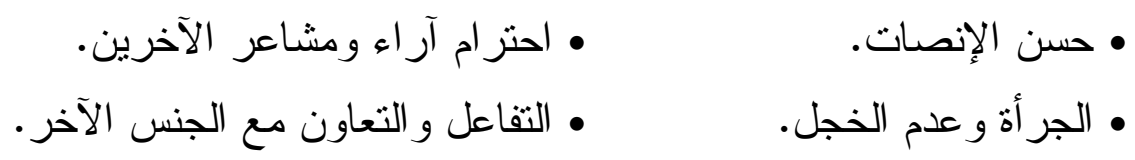

• الثقة بالنفس و القدرة علي مو اجهة الجمهور •

و عن المعوقات و المشكلات التي و اجهت الطلاب أثتاء فترة التدريبات وتعوق

عملية اكتسابهم لمهار ات العمل المسرحي كما أوردها الطلاب كالتالي :

ا - عدم تو افر الإمكانيات المادية المناسبة .

r - عدم اشتر اكنا في عروض مسرحية سابقة .

r - عدم اهتمام إدارة الكلية بالمسرح وتوفير الأدوات و التسهيلات .

ع - ضيق أماكن التدريب و عدم ملاعمتها للبروفات المسرحية و العروض .

ه - قصر فترة ووقت التدريبات المسرحية .

7 - عدم وجود ميز انية للإنفاق علي العروض، وتحملنا الإنفاق عليها .

- V

م - خجل بعض الطلاب

\section{توصيات الدراسة :}

في إطار ما توصلت إلبه الدر اسة من نتائج يمكن طرح عدد من المقترحات، و التي ينبغي تو افر ها من خلال أعضاء هيئة تدريس قسم الإعلام التربــوي و إدارة الكلية و هي كالتالي :

ا - ينبغي وجود ورشة لطلاب قسم الإعلام التربوي يمكن من خلالهــا إجــر اء التدريبات المسرحية علي غرار ورشة النجارة و الخزف بأقسام التربية الفنية، ومعمل الكمبيوتز بقسم الحاسب الآلي، ومعمل الموسيقي بقـم الموســيقي، و معمل الاقتصاد المنزلي . r- ضرورة تو افر الإمكانات المادية من (أخشاب - دهانات - أدو ات ووســائل 


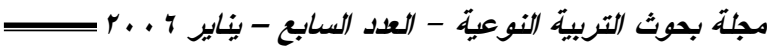

النجارة و الدهان) و أجهزة كمبيوتر ، فيديو، كامير ات تصوير وكثافات إضاءة،

بما يساعد علي التدريب وخدمة العملية التعليمية .

ب- تتظيم الجداول الدر اسية بما يسمح للطلاب ممارسة التطبيقات العملية .

ع - ينبغي علي أعضاء هيئة التذريس و الهيئة المعاونة في تخــص المسسرح

التربوي الاهتمام بالجو انب التطبيقبة .

ه- ينبغي تو افر مبز انية كافية لقسم الإعلام التربوي بما يرفــع عـن الطـلاب

و أسر هم تكاليف و أعباء الدراسة و الإنفاق علي العملية التعليمية .

ج- ينبخي الاهتمام بالجوانب العملية في مجال المسرح، فهي إلى جانــب أنهــا

در اسة للطلاب فهي علي الجانب الآخر نشاط يساعد علي ثقل وتتمية مو اهب

الطلاب و إعدادهم بما يسمح لهم بتطبيق ما تعلموه بعد التخرج. 
فعالية التلريبات المسرحية في إكساب طلاب الإعلام التربوي مهارات العمل المسرحي ـــ

\section{هراجع الدراسة :}

\section{(أ) المراجع العربية:}

ا. إبر اهيم حمادة، "معجم المصطلحات الارامية والمسرحية"، القاهرة: الهئــة العامــة المــصرية

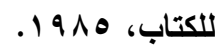

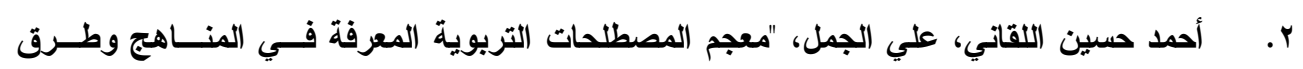

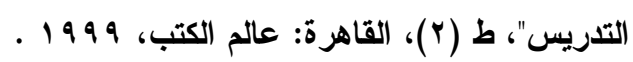

r. أحمد حسين محمد حسن، "الرضا التعليمي للاي طلاب الإعلام التربوي (الــصحافة - المسـرح) ببعض كليات التربية النوعية وعلاقته ببعض المتغيرات الديموجرافية"، المــؤتمر العلمــي الأول

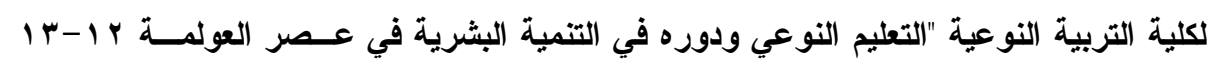

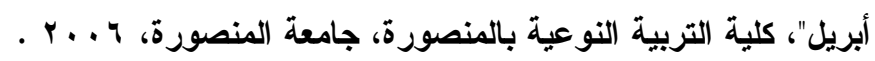
ع. أ.ف بتروفسكي، م.ج. ياروشفسكي، "معجم علم النفس المعاصر"، ترجمة حمــدي عبـــالجواد،

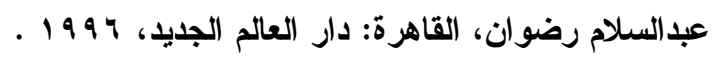

ه. المعجم الوجيز، مجمع اللغة العربية، ج.م.ع، وزارة التربية والتعليم، ـ99 19 . 4. آمال أبو باثنا، "أثر برنامج مقترح لتنمية بعض مهارات الاتصال لاي عينة مــن طـلاب قـسم

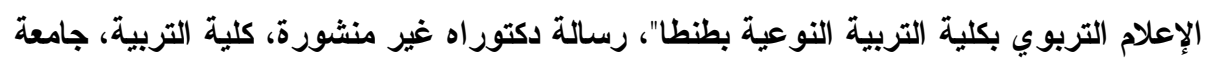

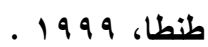

V. أمل عبد الرحمن عيد، "قاعلية استخدام الصحف في تنمية بعض مهارات اللغة الإتجليزية لــدي طلاب شعبة الإعلام التربوي بكليات التربية النوعية"، رسالة دكتوراه غير منشورة، كلية التربية

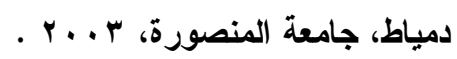

^. جمال مصطفي العيسوي، محمد محمود موسي، "مدى تمكن طالبات كلية التربية جامعة الإمارات

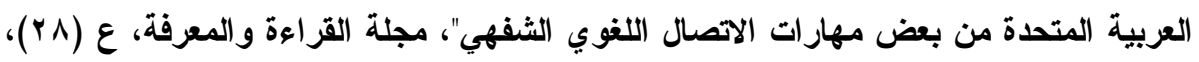

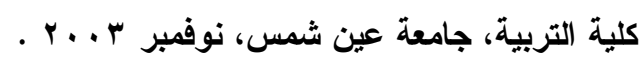

9 9. حسن شحاته، زينب النجار، حامد عمار ، "معجــم المـصطلحات التربويــة و النفـسية" ط ( (1)،

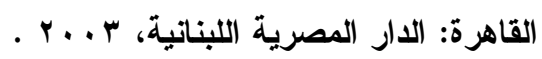




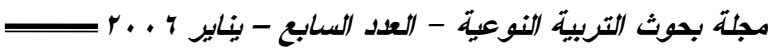

• 1 . راشد محمد عطيه أبو صواوين، "برنامج مقترح لتنمية مهارات التواصل الثفوي لدي طالبـات

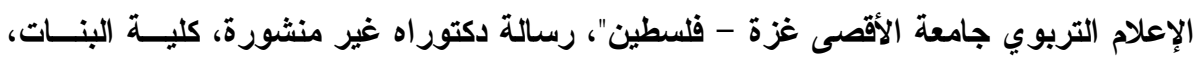

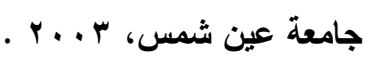

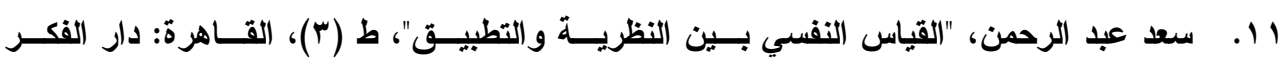

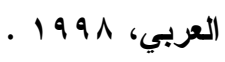

r ا. فراتك م.هوايتتج، "المدخل إلى الفنون المسرحية، ترجمة كامل يوسف وآخرون، القــاهرة: دار

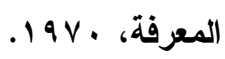

با. ـ كارل النزويرث، "الإخراج المسـرحي"، ترجــة أمسـين ســلامة، القـــاهرة: مكتبــة الأتجلــو

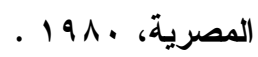

ع ا. كمال دسوق، "نخيرة علوم النفس"، المجلد (ץ)، القاهرة: وكالة الأهر ام للتوزيع، 1991 ـ .

ه1. محمد عاطف غيث، "قاموس علم الاجتماع"، الإسكندرية: دار المعرفة الجامعية، 1990 ـ . 1 1. محمد علي الخولي، "قاموس التربية"، بيروت: دار العلم للملابس، ه1911.

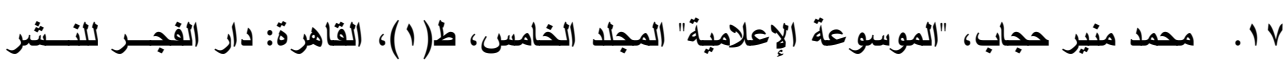

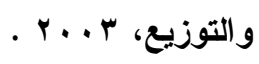

1 ا. محمد منير حجاب، "المعم الإعلامي"، ط(1)، القاهرة : دار القجر للنشر والتوزيع، ؛ . .ب. 9 1. همت حسن عبد المجيد، "تفعيل دور كليات التربية النوعية في رفع كفــاءة أخــصائي الإعـلام

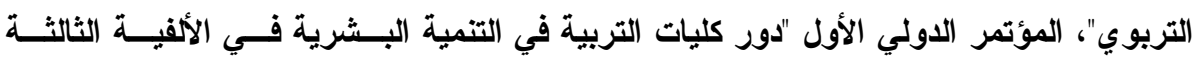

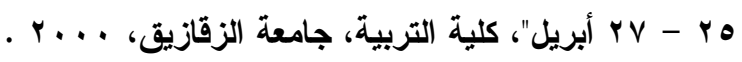

• •. . اللاتحة الاخلية لكليتي التربية النوعية بالمنصورة وفرعيها بميث غمر ومنية النـصر وكليـة

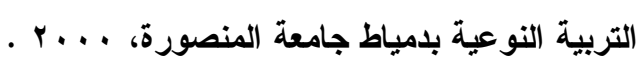

(ب) ) المراجع الأجنبـية )

21. English, HiB \& English A G, 1985 .

22. Goldon son R. U: Long man Dictionary of psychology and psychiatry, New York: Long man, 1984 .

23. Singer, R. N: Motor Learning and human performance mans, N.Y : Macmillan pub co- inc, 1980 . 
فعالية التلريبات المسرحية في إكساب طلاب الإعلام التربوي مهارات العدل المسرحي لـ 